Prepared in cooperation with the Village of East Hampton

\title{
Assessment of Water Quality and Fecal Contamination Sources at Hook Pond, East Hampton, New York
}

Scientific Investigations Report 2020-5071 
Cover. Front: Hook Pond, viewed looking south from a boat during a sampling trip; photograph by Shawn Fisher, U.S. Geological Survey. Back, bottom left: Waterfowl gathered north of Davids Lane along Hook Pond Dreen (locally known as the duck pond); photograph by Tristen Tagliaferri, U.S. Geological Survey. Back, right: A culvert at Fithian Lane where stormwater from New York State Route 27 enters and Hook Pond Dreen passes through; photograph by Shawn Fisher, U.S. Geological Survey. 


\section{Assessment of Water Quality and Fecal Contamination Sources at Hook Pond, East Hampton, New York}

By Shawn C. Fisher, Brendan A. McCarthy, Christopher M. Kephart, and

Dale W. Griffin

Prepared in cooperation with the Village of East Hampton

Scientific Investigations Report 2020-5071 


\title{
U.S. Department of the Interior \\ DAVID BERNHARDT, Secretary
}

\author{
U.S. Geological Survey \\ James F. Reilly II, Director
}

U.S. Geological Survey, Reston, Virginia: 2020

For more information on the USGS - the Federal source for science about the Earth, its natural and living resources, natural hazards, and the environment-visit https://www.usgs.gov or call 1-888-ASK-USGS.

For an overview of USGS information products, including maps, imagery, and publications, visit https://store.usgs.gov/.

Any use of trade, firm, or product names is for descriptive purposes only and does not imply endorsement by the U.S. Government.

Although this information product, for the most part, is in the public domain, it also may contain copyrighted materials as noted in the text. Permission to reproduce copyrighted items must be secured from the copyright owner.

Suggested citation:

Fisher, S.C., McCarthy, B.A., Kephart, C.M., and Griffin, D.W., 2020, Assessment of water quality and fecal contamination sources at Hook Pond, East Hampton, New York: U.S. Geological Survey Scientific Investigations Report 2020-5071, 58 p., https://doi.org/10.3133/sir20205071.

Associated data for this publication:

U.S. Geological Survey, 2020, USGS water data for the Nation: U.S. Geological Survey National Water Information System database, https://doi.org/10.5066/F7P55KJN.

ISSN 2328-0328 (online) 


\section{Acknowledgments}

The project team would like to thank the following cooperators and stakeholders for providing support that enhanced the results and interpretation of the data collected for this study beyond the proposed assessment. Rebecca Molinaro Hansen and Bill Hajek of the Village of East Hampton provided background and technical information about the storm sewer network and Hook Pond. Kenneth Koch and John Genovesi of the Maidstone Club provided access to the property and assistance with installing the monitoring station at the golf cart bridge. Joette Pavelka, Beth Essex, and April DeVoe at the Suffolk County Department of Health Services Public and Environmental Health Laboratory analyzed samples for fecal indicator bacteria.

The project team would also like to thank William Capurso, Michael Noll, and Anthony Chu; Andy Lange; and Banu Bayraktar, all with the U.S. Geological Survey, who assisted in establishing and leveling the continuous monitoring site, streamgaging, and geographic information system (GIS) mapping, respectively. 



\section{Contents}

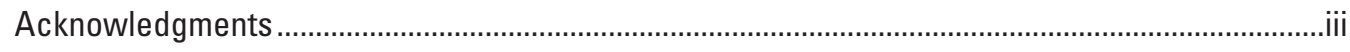

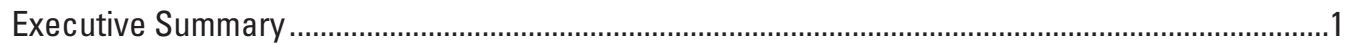

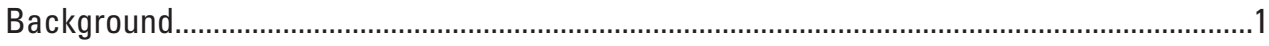

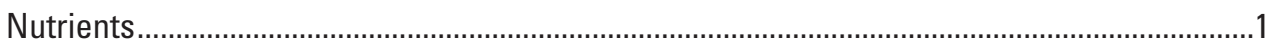

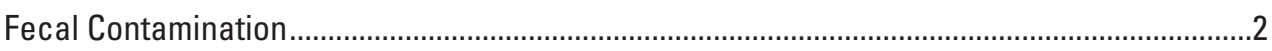

Physicochemical Monitoring and Decision Support .............................................................

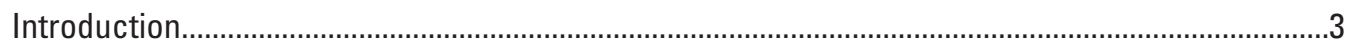

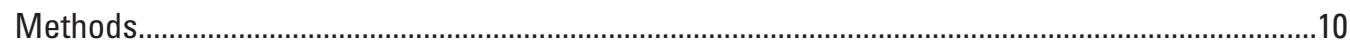

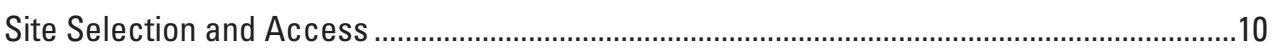

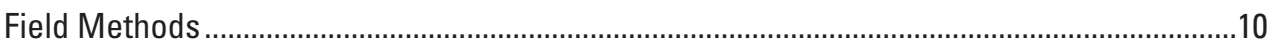

Continuous Water-Quality Monitoring.............................................................................10

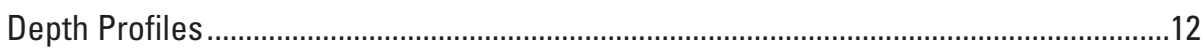

Water-Quality and Microbiological Sample Collection ....................................................12

Stream Discharge Measurements..................................................................................13

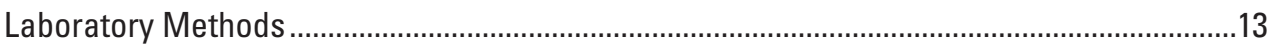

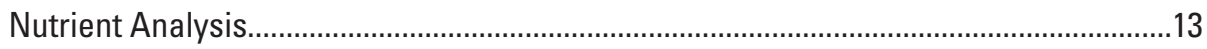

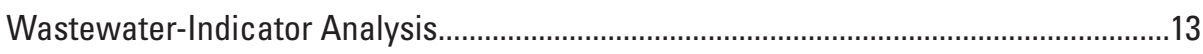

Nitrogen Isotope Analysis .................................................................................... 14

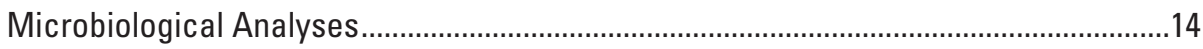

Quality Assurance, Ancillary Data, and Interpretation ....................................................15

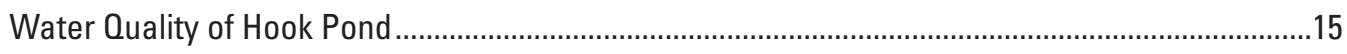

Summary of Continuous Water-Quality Data ...................................................................16

Spatiotemporal Assessment of Physicochemical Constituents in the Hook Pond

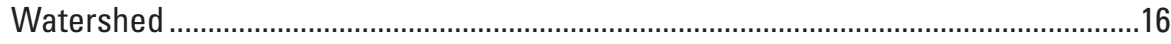

Spatiotemporal Assessment of Nutrients and Wastewater-Indicator Compounds in the Hook Pond Watershed ............................................................................................21

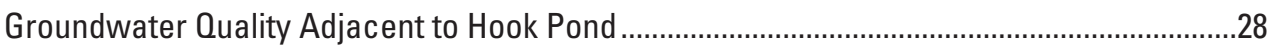

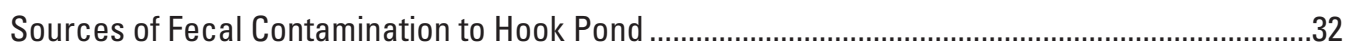

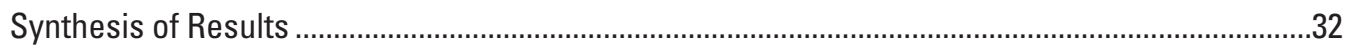

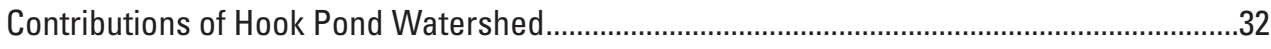

Current Hydrologic Conditions of Hook Pond ...................................................................36

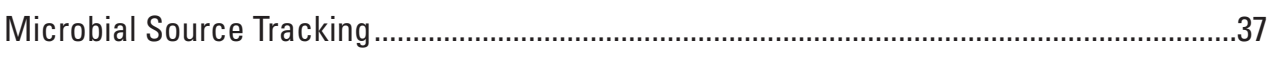

A Baseline for Future Research ........................................................................................

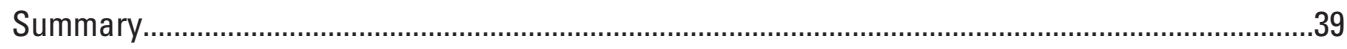

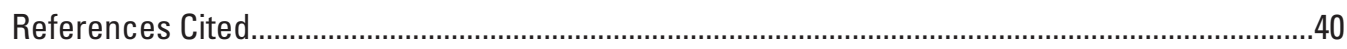

Appendix 1. Expanded Description of Analytical Methods ..........................................................45

Appendix 2. Surface-Water Clarity Plot and Groundwater Constituents........................................50 


\section{Figures}

1. Map showing location of the Hook Pond study area, as well as Georgica Pond, East Hampton Airport, the National Oceanic and Atmospheric Administration (NOAA) Montauk tide gage, and two U.S. Geological Survey groundwater observation wells..

2. Map showing location of Town Pond, Hook Pond Dreen, and Maidstone Club in East Hampton, New York .5

3. Photographs showing Hook Pond at the spillway that drains water to the Atlantic Ocean under adjacent sand dunes; stone culvert at Fithian Lane where stormwater from New York State Route 27 is discharged and Hook Pond Dreen passes through; and Hook Pond Dreen at area of concentrated waterfowl, locally known as the duck pond, East Hampton, New York.

4. Maps of Hook Pond and Hook Pond Dreen sites in East Hampton, New York, where surface-water and groundwater samples were collected.

5. Photograph showing Hook Pond site 10 -continuous water-quality monitor inside a steel pipe secured to a piling on the north side of the Maidstone Club golf cart bridge, East Hampton, New York

6. Graph showing continuous water-temperature and specific conductance data from Hook Pond site 10 recorded at 15-minute intervals, and continuous air-temperature data from East Hampton Airport recorded at 20-minute intervals

7. Graph showing continuous water-surface elevation data from Hook Pond site 10 in East Hampton, New York, continuous water-surface elevation data from nearby Georgica Pond, continuous tide elevation data from the National Oceanic and Atmospheric Administration Montauk tide gage, continuous groundwater elevation data from U.S. Geological Survey observation well S8833.2; daily precipitation data are from East Hampton Airport.

8. Boxplots of physical constituents from August 2017 through August 2018 at sites along Hook Pond Dreen, within Hook Pond, and at the eastern shoreline of Town Pond in East Hampton, New York...

9. Graphs showing concentrations of various forms of nitrogen and total phosphorus collected at Hook Pond site 3 in East Hampton, New York, between August 1, 2017, and July 16, 2018

10. Boxplots showing seasonal representation of nitrogen and phosphorus concentrations in Hook Pond, East Hampton, New York

11. Boxplots showing comparisons of snowmelt, storm, and nonstorm sample events from samples collected from all sites along Hook Pond Dreen, East Hampton, New York

12. Diagram showing stable isotope of oxygen-18 and nitrogen-15 of nitrate in surface-water and groundwater samples collected throughout the Hook Pond watershed, East Hampton, New York.

\section{Tables}

1. Site name, location, and type of sample collected at each site within the Hook Pond watershed, East Hampton, New York.

2. Discharge values determined along Hook Pond Dreen at four U.S. Geological Survey stations in East Hampton, New York, on May 31, 2018. 
3. Concentrations and isotope fractions of nitrogen species collected in the Hook Pond watershed, East Hampton, New York.

4. Concentrations of phosphorus collected in the Hook Pond watershed, East Hampton, New York.

5. Concentrations of wastewater-indicator compounds, U.S. Geological Survey National Water Quality Laboratory schedule 1433, collected in the Hook Pond watershed, East Hampton, New York.

6. Results of fecal indicator bacteria (total coliform, fecal coliform, Escherichia coli, and enterococci), microbial source tracking (MST), and F+-specific coliphage analyses from samples collected for microbial source tracking within the Hook Pond watershed, East Hampton, New York

\section{Conversion Factors}

U.S. customary units to International System of Units

\begin{tabular}{|c|c|c|}
\hline Multiply & By & To obtain \\
\hline \multicolumn{3}{|c|}{ Length } \\
\hline inch (in.) & 2.54 & centimeter $(\mathrm{cm})$ \\
\hline inch (in.) & 25,400 & micrometer $(\mu \mathrm{m})$ \\
\hline foot $(\mathrm{ft})$ & 0.3048 & meter $(\mathrm{m})$ \\
\hline mile (mi) & 1.609 & kilometer (km) \\
\hline \multicolumn{3}{|c|}{ Area } \\
\hline acre & 4,047 & square meter $\left(\mathrm{m}^{2}\right)$ \\
\hline \multicolumn{3}{|c|}{ Volume } \\
\hline ounce, fluid (fl. oz) & 29.57 & milliliter (mL) \\
\hline ounce, fluid (fl. oz) & 29,570 & microliter $(\mu \mathrm{L})$ \\
\hline gallon (gal) & 3.785 & liter $(\mathrm{L})$ \\
\hline \multicolumn{3}{|c|}{ Flow rate } \\
\hline cubic foot per second $(\mathrm{ft} 3 / \mathrm{s})$ & 0.02832 & cubic meter per second $\left(\mathrm{m}^{3} / \mathrm{s}\right)$ \\
\hline \multicolumn{3}{|c|}{ Hydraulic conductivity } \\
\hline foot per day (ft/d) & 0.3048 & meter per day $(\mathrm{m} / \mathrm{d})$ \\
\hline
\end{tabular}

Temperature in degrees Celsius $\left({ }^{\circ} \mathrm{C}\right)$ may be converted to degrees Fahrenheit $\left({ }^{\circ} \mathrm{F}\right)$ as ${ }^{\circ} \mathrm{F}=\left(1.8 \times{ }^{\circ} \mathrm{C}\right)+32$.

Temperature in degrees Fahrenheit $\left({ }^{\circ} \mathrm{F}\right)$ may be converted to degrees Celsius $\left({ }^{\circ} \mathrm{C}\right)$ as ${ }^{\circ} \mathrm{C}=\left({ }^{\circ} \mathrm{F}-32\right) / 1.8$. 


\section{Datum}

Vertical coordinate information is referenced to the North American Vertical Datum of 1988 (NAVD 88), having been converted from values referenced to the National Geodetic Vertical Datum of 1929 (NGVD 29).

Horizontal coordinate information is referenced to the North American Datum of 1983 (NAD 83). Elevation, as used in this report, refers to distance above the vertical datum.

\section{Supplemental Information}

Specific conductance is given in microsiemens per centimeter at 25 degrees Celsius $(\mu \mathrm{S} / \mathrm{cm}$ at $\left.25^{\circ} \mathrm{C}\right)$.

Concentrations of chemical constituents in water are given in either milligrams per liter (mg/L) or micrograms per liter $(\mu \mathrm{g} / \mathrm{L})$.

Turbidity is reported in formazin nephelometric units.

\section{Abbreviations}

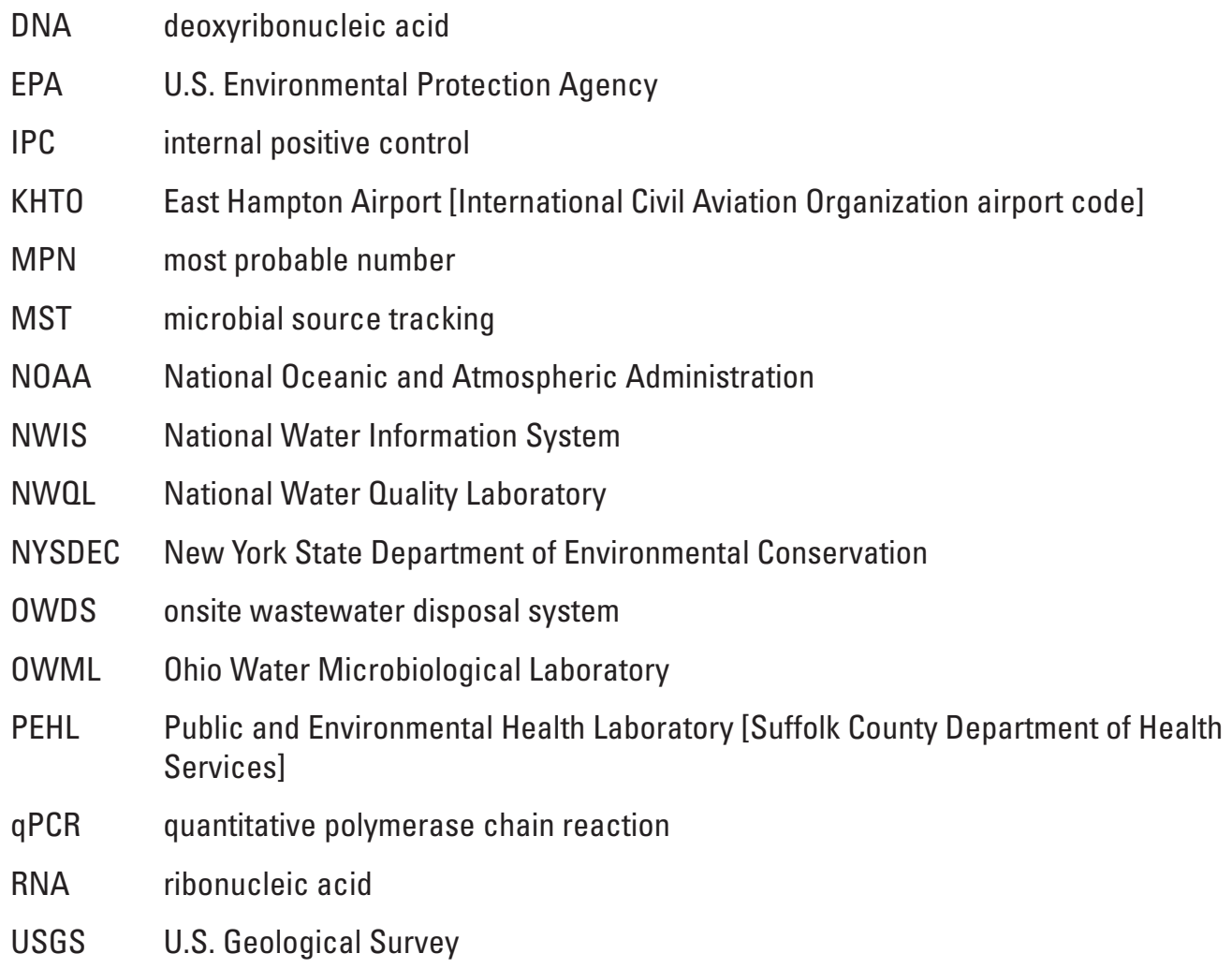

USGS U.S. Geological Survey 


\title{
Assessment of Water Quality and Fecal Contamination Sources at Hook Pond, East Hampton, New York
}

\author{
By Shawn C. Fisher, Brendan A. McCarthy, Christopher M. Kephart, and Dale W. Griffin
}

\section{Executive Summary}

The U.S. Geological Survey, in cooperation with the Village of East Hampton, New York, conducted a 1-year study from August 2017 to August 2018 to provide data necessary to improve understanding of the sources of nutrients and pathogens to Hook Pond and their extents in order to allow for possible mitigation or reduction of loads. The Hook Pond Water Quality Improvement Project was used as a starting point based on several recommendations and data and monitoring gaps identified by Lombardo Associates, Inc. The "Recommended Monitoring Program and Water Quality Restoration Goals" section of the Water Quality Improvement Project was referenced while developing a sampling strategy, based on resources available, in consultation with the Village of East Hampton. In addition to filling gaps, the strategy was developed to assess current and seasonal conditions related to nutrients, physicochemical constituents, and pathogens to further inform management decisions and provide a baseline for future research and monitoring of the Hook Pond and its watershed.

\section{Background}

Hook Pond is chronically eutrophic and is listed as a class $\mathrm{C}$ waterbody in the Priority Waterbodies List of the New York State Department of Environmental Conservation: it is suitable for general recreation use (secondary contact) and to support aquatic life, but not for public bathing. The issue of eutrophication is often associated with urban development and subsequent loading of inorganic forms of nitrogen and phosphorus to the groundwater and surface waters. In the past 10 years, harmful cyanobacterial blooms in Hook Pond and other eastern Long Island freshwater bodies have spurred concerns about the nonpoint source loading of nutrients and pathogens from cesspools and septic tank leachfields (collectively, onsite wastewater disposal systems [OWDS]) to groundwater and ultimately to adjacent waterbodies. Elevated concentrations of fecal indicator bacteria have also been regularly documented by the Concerned Citizens of Montauk in areas of high waterfowl populations along Hook Pond Dreen where human contact with the water is likely. Lastly, water-surface elevation data collected for this study provide the baseline needed for comparison in future surveys aimed at determining the rate at which sedimentation is affecting Hook Pond, leading to filling and loss of depth and shoreline. Hook Pond, along with Town Pond, is being considered for dredging by the village. In a broader sense, this study can provide resource managers with information to help protect groundwater and surface-water resources of coastal communities throughout Suffolk County.

\section{Nutrients}

A comprehensive water-quality assessment of Hook Pond, its tributary Hook Pond Dreen, and shallow groundwater adjacent to these surface waters was conducted to determine seasonal and event-based variability in nutrient (nitrogen and phosphorus) concentrations. Along Hook Pond Dreen, concentrations of nitrogen and phosphorus were typically highest at Fithian Lane and became diluted downstream prior to reaching Hook Pond. Elevated ammonia concentrations at Fithian Lane can be attributed to anoxic groundwater (that is, with low dissolved oxygen) contributing to base flow, whereas at Davids Lane, ammonia is lower and nitrate concentrations are higher because of influence from the groundwater surrounding Hook Pond Dreen (which is oxic and high in nitrate) and nitrification in the water column. In Hook Pond, concentrations of different forms of nitrogen (nitrate, ammonia, and total nitrogen) varied in surface-water samples throughout the year because of the variability of phytoplankton, which readily take up nitrate (which ranged from a low of 0.02 milligram per liter $[\mathrm{mg} / \mathrm{L}]$ as nitrogen in the summer to $2.6 \mathrm{mg} / \mathrm{L}$ as nitrogen in the winter) and orthophosphate (which was not detected above the reporting limit [0.004 $\mathrm{mg} / \mathrm{L}$ as phosphorus]) in samples collected throughout Hook Pond.

Total phosphorus concentrations were relatively stable within Hook Pond but increased under wet weather conditions. During periods of rain and snowmelt, spikes in total phosphorus were observed entering Hook Pond Dreen at Fithian Lane (reaching $0.53 \mathrm{mg} / \mathrm{L}$ as phosphorus); high concentrations of phosphorus were also detected at Davids Lane regardless of the hydrologic event, likely as a result of high concentration of waterfowl (and waterfowl feces) in the area. In surface waters, wastewater-indicator compounds, such as domestic care products and biomolecules, were correlated with higher 
concentrations of phosphorus and ammonia during periods of high flow due to wet weather. However, concentrations of wastewater-indicator compounds were below detection limits in groundwater samples with elevated nutrients. Stable isotope analyses of nitrogen $\left(\delta^{15} \mathrm{~N}\right)$ and oxygen $\left(\delta^{18} \mathrm{O}\right)$ of nitrate are consistent with results from other coastal samples collected throughout Long Island, and these analyses and results indicate OWDSs and the application of manure as sources of elevated nitrogen concentrations; nitrogen from both sources leaches into groundwater, which travels downgradient and provides base flow for Hook Pond Dreen.

\section{Fecal Contamination}

Seasonal and spatial variability of fecal indicator bacteria was assessed, and the data were coupled with microbial source tracking (MST) techniques to improve understanding of the extents and sources of pathogens to Hook Pond and Hook Pond Dreen. Bacterial and viral deoxyribonucleic acid (DNA)-based and ribonucleic acid (RNA)-based markers (respectively) were used to help determine potential sources of elevated fecal indicator bacteria detected along Hook Pond Dreen in areas where the public is near, and in some cases in contact with, the water. Five points along Hook Pond Dreen and in southwestern Hook Pond were found to likely be influenced by human sources, possibly from failing OWDSs overflowing or discharging through illicit hookups to stormwater conveyances. Human markers were also found during a winter snowmelt event $\left(\mathrm{F}^{+}\right.$-specific coliphage, group III) and spring rainstorm (Bacteroides, HF183). As seen in other parts of Long Island, however, there were no detections of fecal indicator bacteria or MST markers in shallow groundwater adjacent to the pond and tributary, supporting the conclusion that groundwater transport of pathogenic bacteria through a sandy subsurface is limited and does not affect surface waters.

The waterfowl MST marker (GFD) was detected at the highest concentration in the study area at Davids Lane during both storm and nonstorm conditions and correlated with high concentrations of the fecal indicator bacteria genus enterococci and species Escherichia coli. Consistent with data collected elsewhere on Long Island, the ruminant MST marker (Rum2Bac) was infrequently detected, suggesting minimal contributions of animals such as deer, and these contributions are not unexpected in areas with little pavement and limited stormwater runoff from wooded areas and lawns. Conversely, detection of the canine MST marker was ubiquitous and, particularly at Davids Lane, these detections were at some of the highest concentrations on Long Island (at greater than $1,400,000$ copies per 100 milliliters) relative to concentrations from the other waterbodies currently being assessed by the U.S. Geological Survey (USGS). And while the MST methods do not allow for direct quantification of host contributions of fecal indicator bacteria to Hook Pond Dreen, it can be said that the major contributors to the persistent elevated enterococci concentrations documented by Concerned Citizens of Montauk are waterfowl and canine sources at Davids Lane.
These results can help village managers decide where to direct stormwater remediation controls, implement practices to limit pet waste from reach waters, and warn members of the public about the potentially harmful water and inform them of its sources.

\section{Physicochemical Monitoring and Decision Support}

Physicochemical constituents (water temperature, specific conductance, $\mathrm{pH}$, dissolved oxygen, turbidity, and chlorophyll $a$ and phycocyanin fluorescence) at sites throughout Hook Pond were compared to obtain a year-round assessment of conditions and to inform the positioning of a future continuous water-quality monitoring station as efficiently as possible. Most measurements of physicochemical constituents (such as specific conductance, dissolved oxygen, $\mathrm{pH}$, and turbidity, and phycocyanin fluorescence) collected on the same day were consistent spatially across Hook Pond. Data collected as part of this study confirmed elevated concentrations of phosphorus and reduced water clarity throughout the year in Hook Pond, and relatively high chlorophyll $a$ concentrations in the summer. Notable observations made throughout this study include the following: (1) chlorophyll $a$ and phycocyanin concentrations were higher in the lower, wider part of the pond, and the difference between these concentrations and those from the upper part of the pond, where the continuous water-quality monitor was located, was statistically significant; (2) chlorophyll $a$ did not correlate with turbidity or water clarity, suggesting that dissolved organic matter also contributes to water clarity; (3) $\mathrm{pH}$ and chlorophyll $a$ are weakly correlated, but only when data from Hook Pond Dreen are included, which results in concentrations and $\mathrm{pH}$ values being included at the lower end of the graph; and (4) trends and values of water temperature track closely with those of air temperature (from East Hampton Airport), except during periods of freeze and thaw, because of the shallow depths.

In addition to the profile data collected, data from continuous monitoring of water temperature, specific conductance, and elevation at Hook Pond site 10 (at the Maidstone Club golf cart bridge) over the 1-year period provided context for discrete water-quality data and were compared to depth-profile samples collected throughout Hook Pond, transects of Hook Pond Dreen, and discrete measurements of nearby Town Pond. The spike (and subsequent steady decrease) in specific conductance observed at the continuous water-quality monitoring site (Hook Pond site 10) in the winter of 2018 is an example of changes in dissolved solids (that is, elements that increase conductivity in water) that can be used as a proxy for contamination pulses from known sources. Sodium and chloride (two components of road salt) are considered conservative elements (meaning they are typically not reactive in the water column or downstream) and can be used as tracers. Further, these data can be useful for determining a better estimate of the flushing rate of Hook Pond. 
The continuous water-quality data provided highresolution measurements (at 15-minute intervals) that can be used to help monitor many of the issues facing resource managers: the gradual filling of Hook Pond; a rising sea level and groundwater elevation; trends in water temperatures resulting from a changing climate; and influences from upstream stormwater conveyance, including metals and salts and pathogens to Hook Pond Dreen. Monitoring of specific conductance can be used to track contaminants associated with stormwater runoff (for example, through the pulses of road salt following snowmelt that were observed in this study) and land-use practices (such as, fertilizer applications) in areas adjacent to the pond and tributaries. Specific conductance monitoring data can also be used as a long-term indicator for changes within the watershed, such as incremental increases in groundwater conductivity related to OWDSs, road salt, and other practices. Pond water-surface elevation data can help determine rates of filling or sedimentation, influences of a rising sea level or groundwater elevation, and changes associated with mitigation practices such as dredging.

The results can be used to help determine a candidate location for future continuous water-quality monitoring, and the location would depend on the desired information: contributions of stormwater runoff to Hook Pond (from contaminants related to road salts, metals, nutrients, or wastewater, for example), continuous loading and cycling of nutrients to Hook Pond resulting in eutrophication and potentially recurrence of harmful cyanobacterial blooms, or pond water flush rates. Data collected from depth profiles were correlated with watersurface elevation to determine lakebed elevation, which can be compared with future surveys to help assess the extent to which the pond may be filling with sediment and organic matter, and correlated with groundwater elevations from nearby wells, which can improve understanding of how the water table rises as the climate changes.

Currently (2020), the USGS is working in cooperation with the New York State Department of Environmental Conservation under the Long Island Nitrogen Action Plan to better delineate groundwater recharge areas throughout Long Island and compute travel times to better define outflows to surface waters. When completed, the resulting maps will provide improved resolution of boundaries and the movement of groundwater within the Hook Pond watershed and, when used in conjunction with nutrient data from this study, could be used as a tool to estimate loading to the pond.

\section{Introduction}

Hook Pond is a shallow, 80-acre freshwater pond in East Hampton, New York (fig. 1), influenced by surrounding residential and agricultural land use since the late 1600s. The Hook Pond watershed includes two tributaries: Hook Pond Dreen and a system of underground pipes and open wetlands that drain Town Pond (fig. 2). Water level in the pond is controlled by a spillway at the south end, which is piped under a narrow dune and out to the Atlantic Ocean; the system of pipes is operated by the Village of East Hampton and the Maidstone Club (golf course) (figs. 2 and 3A). Groundwater in the shallow, unconsolidated aquifer consisting mostly of sand and silt contributes base flow to Hook Pond Dreen and seepage to Hook Pond. Historically, Hook Pond was used for recreational bathing and fishing; however, impairments to water quality related to historical and current land uses have limited its recommended uses and threaten ecological health.

Although Hook Pond is not included in the New York State Department of Environmental Conservation (NYSDEC) 303(d) List of Impaired Waters (NYSDEC, 2016a), it is listed as a class $\mathrm{C}$ waterbody in the Priority Waterbodies List (NYSDEC, 2016b), indicating that it is suitable for general recreation use (secondary contact) and to support aquatic life but not for public bathing. Impairments in this shallow pond resulting from current and historical land-use practices include elevated concentrations of organic and inorganic forms of nitrogen and phosphorus (collectively, nutrients) and low dissolved oxygen concentrations in bottom waters (Lombardo Associates, Inc., 2015; NYSDEC, 2016b). Recent (2016) harmful cyanobacterial blooms in Hook Pond and other eastern Long Island freshwater bodies have spurred concerns about the nonpoint source loading of nutrients from cesspools and septic tank leachfields (collectively, onsite wastewater disposal systems [OWDSs]) to groundwater and ultimately to adjacent waterbodies.

As with most freshwater ponds influenced by urbanization, Hook Pond is eutrophic and exhibits diurnal and seasonal fluctuations in dissolved oxygen concentrations and $\mathrm{pH}$ (Feinson and others, 2016; Hasler, 1947). Land use within the Hook Pond watershed is dominated by low- and mediumdensity residential areas with some light commercial, agriculture, and transportation infrastructure, as well as a golf club that contacts about half the shoreline. Nutrients and pathogens (disease-causing organisms, such as specific types of bacteria and viruses) entering a watershed can vary in type and concentration based on land use and characteristics (for example, paved or unpaved, sewered or not sewered, and urban or wildlife habitat). In addition to groundwater seepage, stormwater runoff from impervious (paved) areas within the watershed drains into storm sewers that discharge to Hook Pond Dreen (fig. 3B) and Town Pond, contributing to elevated concentrations of nutrients, dissolved solids and other major ions, organic contaminants, and pathogens (Lombardo Associates, Inc., 2015).

Influences from OWDSs on the groundwater within the Hook Pond watershed are believed to contribute a substantial amount of the inorganic nitrogen and phosphorus load to Hook Pond and have been well documented in areas with similar sandy glacial sediment (Fisher and others, 2016). Particularly relevant is the analysis by Monti and Scorca (2003), which documents increasing trends in nitrogen concentrations in streams along the south shore of Suffolk County (New York) resulting from increased population and development and 


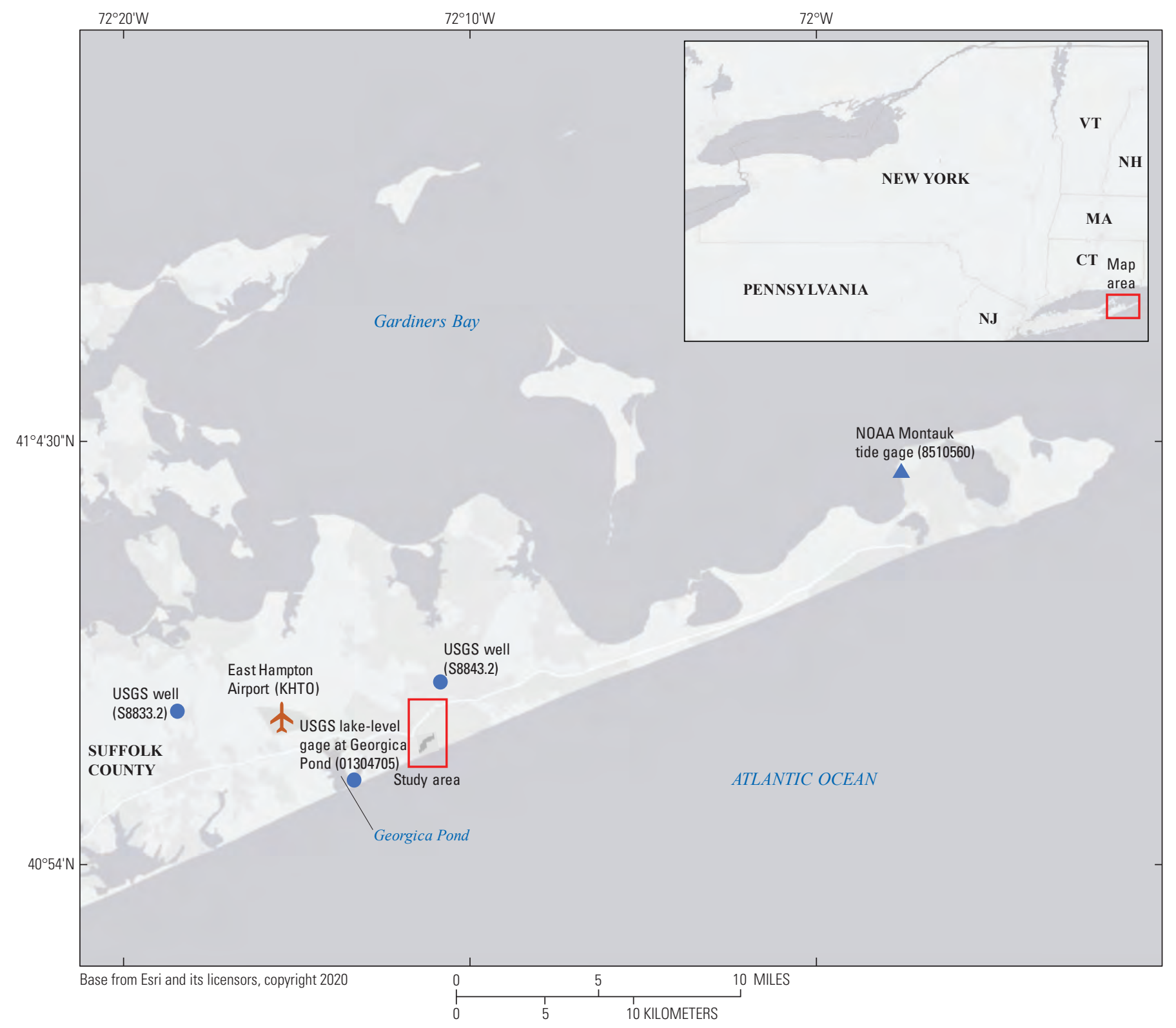

Figure 1. Location of the Hook Pond (East Hampton, New York) study area, as well as Georgica Pond, East Hampton Airport (KHTO), the National Oceanic and Atmospheric Administration (NOAA) Montauk tide gage (8510560), and two U.S. Geological Survey (USGS) groundwater observation wells (S8833.2 and S8843.2).

decreasing trends in Nassau County (New York) resulting from the implementation of centralized sewering. Further, a study by Walter and others (1996) identified phosphorus plumes downgradient of shallow OWDSs in Cape Cod, Massachusetts, which is hydrologically similar to the south shore of Long Island. In some studies that seek to better understand contributions and sources of nitrogen (such as nitrogenbased fertilizers and septic influences), isotope signatures of nitrate and ammonium have been evaluated and used to track changes in speciation resulting from natural denitrification and microbial processes in groundwater and surface waters (Burns and others, 2009).
Phosphorus is a primary determinant of trophic state (Carlson, 1977) and is often a limiting nutrient in freshwater systems. Phosphorus concentration contributes to eutrophication and increased algal growth (O’Neil and others, 2012). A local example is Mill Pond (Water Mill, N.Y.), where elevated phosphorus concentrations are believed to be the major contributor to systemic algal blooms throughout the summer months (The Southampton Press, 2009). Further, emerging research into harmful cyanobacterial blooms in freshwater systems not only implicates elevated concentrations of phosphorus (both soluble reactive phosphorus [orthophosphate] and total phosphorus) but also the various forms of 


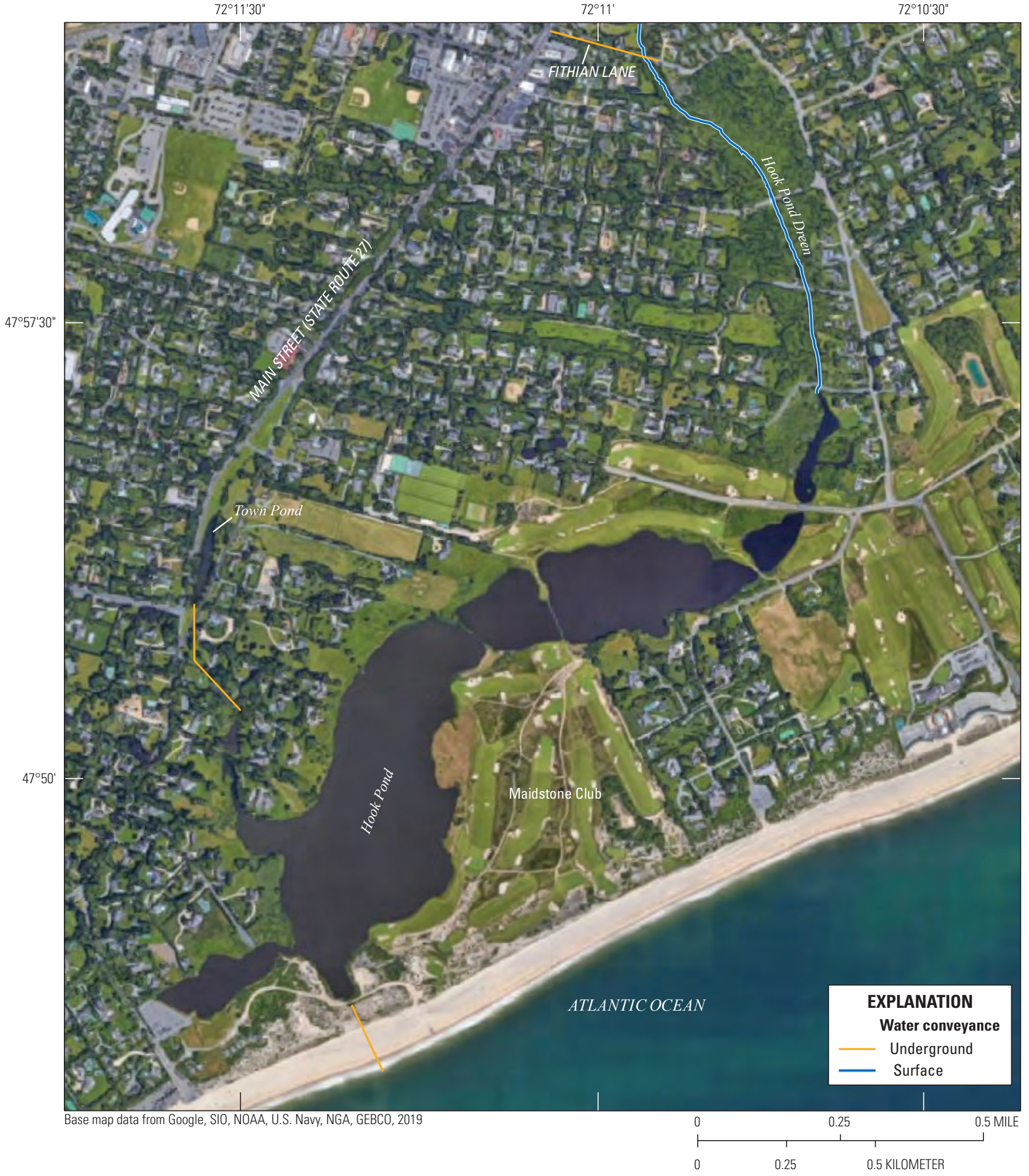

Figure 2. Location of Town Pond, Hook Pond Dreen, and Maidstone Club in East Hampton, New York. Blue line represents Hook Pond Dreen, orange lines represent underground water-conveyance infrastructure-stormwater from State Route 27 (along Fithian Lane discharging to Hook Pond Dreen), Town Pond drainage (through underground and wetlands), and the Hook Pond spillway (overflow to Atlantic Ocean). 
$\boldsymbol{A}$

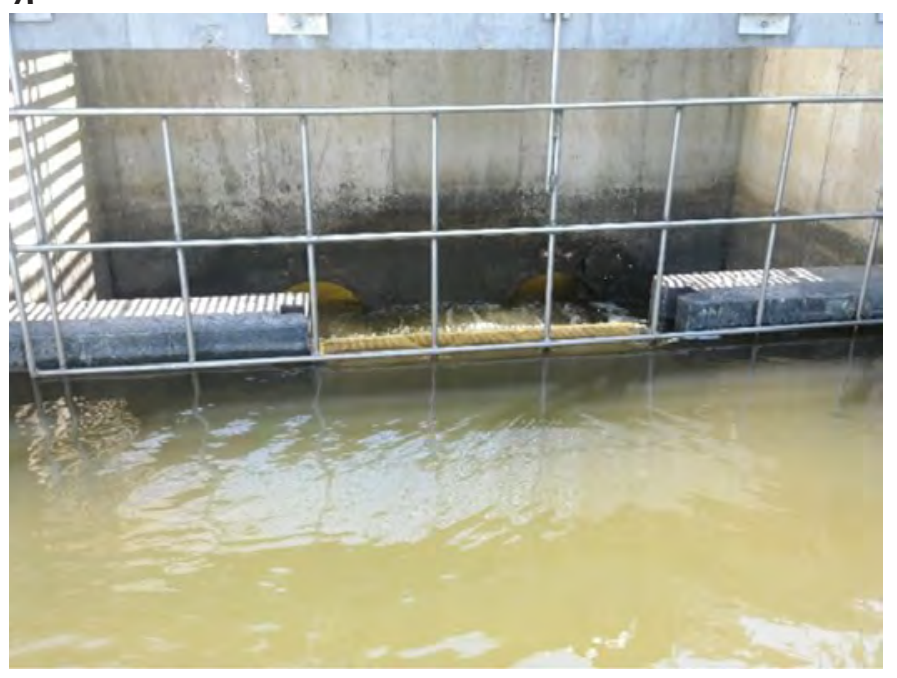

C

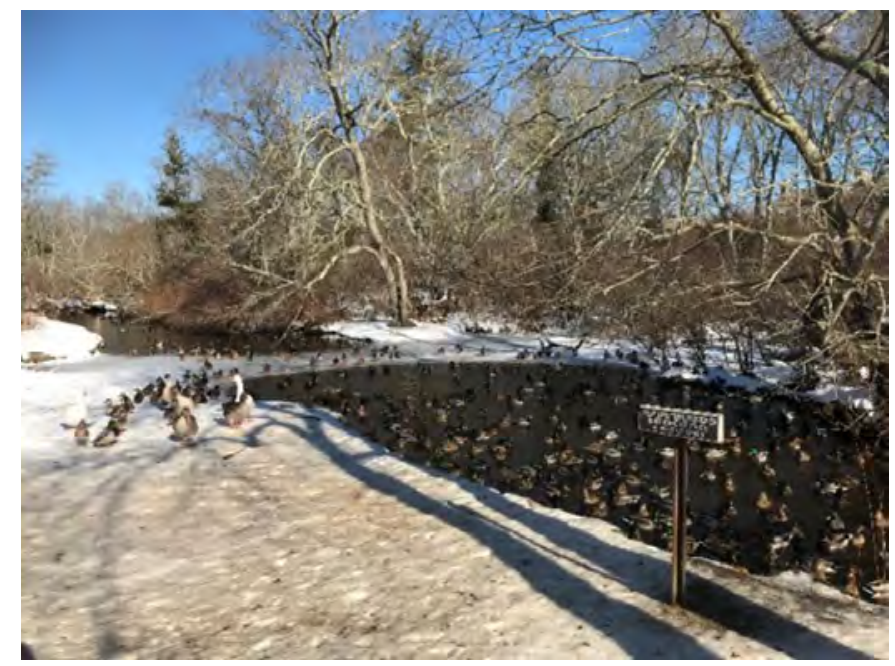

B

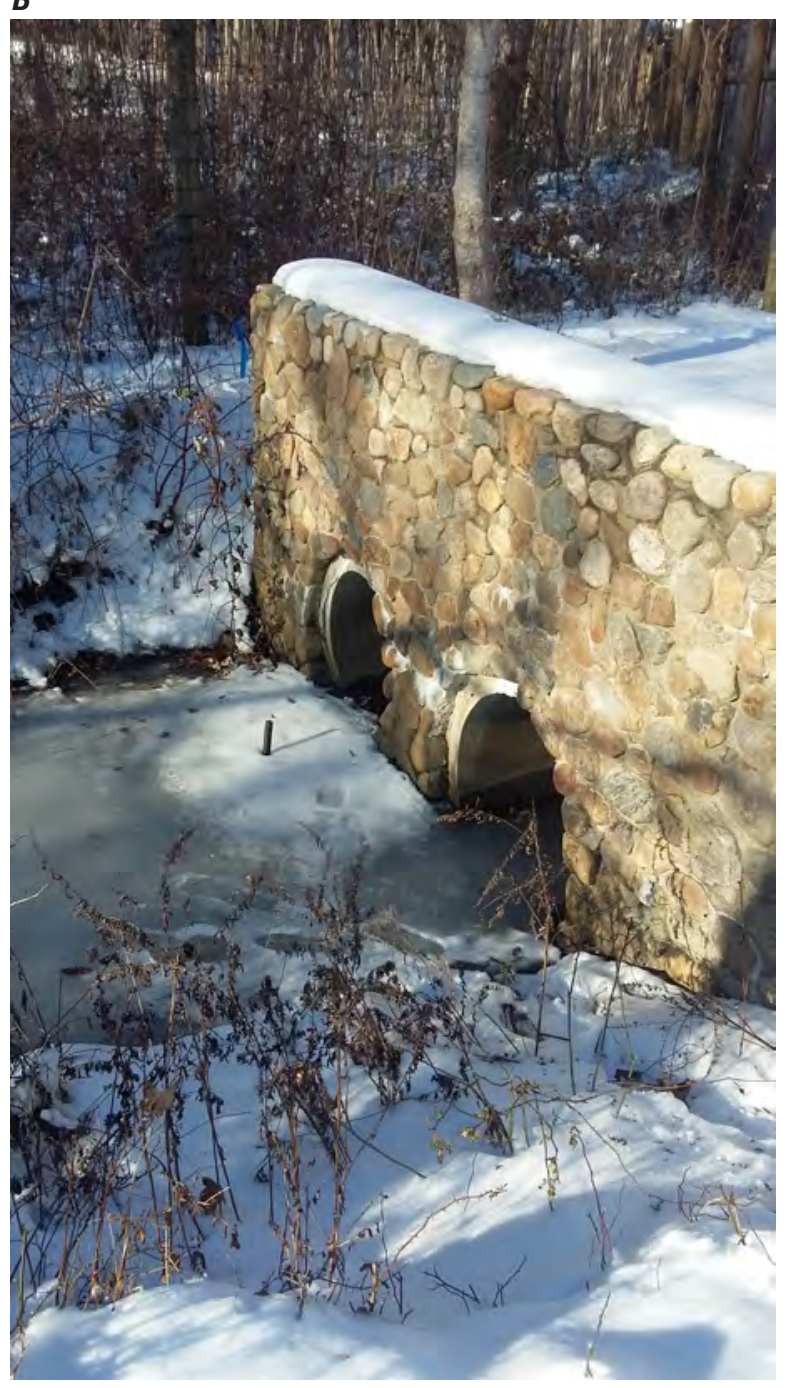

Figure 3. $A$, Hook Pond at the spillway that drains water to the Atlantic 0 cean under adjacent sand dunes; $B$, stone culvert at Fithian Lane where stormwater from New York State Route 27 is discharged and Hook Pond Dreen passes through; and $C$, Hook Pond Dreen at area of concentrated waterfowl, locally known as the duck pond, East Hampton, New York. Photographs $A$ and $B$ by Shawn C. Fisher and $C$ by Tristen N. Tagliaferri, both of the U.S. Geological Survey.

nitrogen — nitrate, nitrite, ammonium, and organic nitrogenas potentially influencing the extent of toxicity (Newell and others, 2019). Sedimentation and plant matter from leaves and grass clippings cause increases in the total nitrogen, total phosphorus, and organic carbon loads, which can promote harmful bloom conditions (O'Neil and others, 2012). As such, street sweeping for leaf litter removal within urban watersheds has been shown to decrease phosphorus loads to receiving freshwater bodies (Selbig, 2016). Results of a 1981 survey of the pond bottom (presented in the Water Quality Improvement Project; Lombardo Associates, Inc., 2015) indicated high concentrations of total phosphorus (0.12-1.7 milligrams per liter $[\mathrm{mg} / \mathrm{L}])$ and total nitrogen $(1.3-1.9 \mathrm{mg} / \mathrm{L})$ in Hook Pond bed sediment, attributed to golf course and lawn maintenance and feces from the resident waterfowl. These sources, along with road runoff and other contributions, are considered external loads. Based on these concentrations, cycling and resuspension of bed sediment into the water column (internal loading) by wind, aquatic wildlife, and recreational activities, could substantially increase the amount of bioavailable phosphorus for phytoplankton and other microalgae and bacteria (Hupfer and Lewandowski, 2008; Kaiserli and others, 2002), particularly during periods of anoxia when mobilization can occur, such as night through early morning and in summer months (Newell and others, 2019).

In addition to concerns over eutrophication and harmful cyanobacterial blooms, pathogen loading associated with human and pet waste and an abundance of wildlife can cause human and ecological health concerns (Jang and others, 2017). As a representative for concentrations of actual pathogens 
related to humans and other warm-blooded animals in water and sediment, fecal indicator bacteria, such as Escherichia coli (E. coli), fecal coliform bacteria, and enterococci, are monitored by State and local health departments, and this monitoring is used to regulate swimming and shellfishing in fresh and marine waters. Although bathing and shellfishing are not common at Hook Pond or along Hook Pond Dreen, continued loading of pathogens from waterfowl or from overflowing or failing OWDSs within a watershed can result in harm to local wildlife and risk to the health of those who catch fish (Jang and others, 2017) or come in contact with the water at local gathering locations (such as the area of Hook Pond Dreen at Davids Lane locally called the "duck pond," where many resident waterfowl are present most days [figs. $3 C$ and 4]). The Concerned Citizens of Montauk and Surfrider Foundation support weekly sampling at two to four sample locations at Hook Pond and along Hook Pond Dreen to help inform local officials on wildlife and wastewater management and have routinely detected high concentrations of enterococci (typically $>24,000$ most probable number [MPN]/100 milliliters [mL]) at the duck pond along Hook Pond Dreen and at Dunemere Lane; whereas concentrations are typically low at the south end of Hook Pond, except when waterfowl are present (Concerned Citizens of Montauk, 2020).

In addition to identifying and quantifying fecal indicator bacteria, microbial source tracking (MST) provides analytical methods for determining the likely fecal source of bacteria (such as human, dog, waterfowl, or deer). The MST method has proven effective in correlating sources and receptors in fresh and marine waters (Kildare and others, 2007), including nearby Georgica Pond (Gobler and others, 2018). Of these studies, many have used selected bacterial genetic sequences related to distinct fecal sources (MST markers). The analytical technique used to quantify MST markers is the quantitative polymerase chain reaction (qPCR). Another MST method uses coliphage viruses, which are derived from $E$. coli found in various types of mammalian feces and whose RNA can be used for source tracking. Currently (2020), the U.S. Environmental Protection Agency (EPA) is working on approving laboratorybased coliphage methods for monitoring beach and shellfish areas and advisories to supplement the current suite of fecal indicator bacteria (EPA, 2019a). Although coliphages are indicative of fecal contamination, the sensitivity of these methods is not ideal for low-level detections. Consequently, enrichment methods for male-specific $\left(\mathrm{F}^{+}\right.$-specific) coliphages have been developed to allow for partial quantification via the polymerase chain reaction method, which is used to discern between human and other animal sources (Griffin and others, 2000). Correlations between MST markers and $\mathrm{F}^{+}$-specific coliphages and fecal indicator bacteria concentrations (and overall water quality) have been conducted in urban and agricultural areas to help determine relative contributions of pathogen sources (Griffin and others, 2000).

Many of the preliminary water- and sediment-quality assessments and studies from the past 40 years have been outlined in the Hook Pond Water Quality Improvement Project
(Lombardo Associates, Inc., 2015), which summarizes the recent efforts, including those by the U.S. Geological Survey (USGS), to collect water-quality data in Hook Pond, its tributaries, and groundwater within its watershed. Previous monitoring by the USGS includes seasonal and storm-related water-quality monitoring in Hook Pond, which was part of a network of freshwater ponds in the Towns of Southampton and East Hampton from 2000 to 2006. Available data include water temperature, $\mathrm{pH}$, specific conductance, and dissolved oxygen from vertical profiles through the water column from the center of Hook Pond. Laboratory analyses of samples from the pond included those for nutrients, major ions, pesticides, and other organic compounds associated with human activities (such as personal care products; biomolecules; and compounds associated with automobile use, industry, and agriculture). The study was conducted to provide data necessary to calculate nutrients loading to the freshwater systems on the South Fork of Long Island, including contributions from shallow groundwater. Additionally, the USGS measured streamflow at one of the two tributaries to Hook Pond biannually (spring and fall) in the mid-1970s and from 2001 to 2008.

Other recent data collection efforts conducted at Hook Pond were limited to research efforts investigating algal and cyanobacterial blooms. These efforts are useful for understanding ecological effects of algae and cyanobacteria and any associated toxins. However, as of 2015, nutrient and physicochemical data had not been collected at a frequency needed to understand the role of stormwater, irrigation, dredging, and groundwater in pond impairments. The Hook Pond Water Quality Improvement Project identifies the perceived gaps in monitoring that would improve predicted loading models and allow for informed decisions to be made about these factors. Among these gaps, an assessment of current nutrient concentrations in the Hook Pond watershed and their sources (that is, groundwater and stormwater) throughout the year was recommended. Additionally, more intensive water-quality monitoring of physicochemical constituents (that is, temperature, specific conductance, $\mathrm{pH}$, dissolved oxygen, and total algae fluorescence) in Hook Pond was also recommended. Based on these recommendations, the USGS, in cooperation with the Village of East Hampton, developed a monitoring strategy, implemented from August 2017 to August 2018, to address concerns about elevated ambient nutrient concentrations in Hook Pond as they relate to eutrophication and cyanobacterial blooms and established a continuous water-quality monitoring site to help document daily variations in water temperature, specific conductance (which can be used to calculate salinity), and pond elevation.

Data collected for this study provide insight into seasonal differences in nutrient and fecal bacteria concentrations and sources to inform loading models and aid in the development of more effective methods for mitigating inputs. Continuous monitoring of water temperature, elevation, and specific conductance can be used to understand diurnal, seasonal, and weather-related changes to the physicochemical properties of Hook Pond and Hook Pond Dreen and, coupled with 
$\boldsymbol{A}$

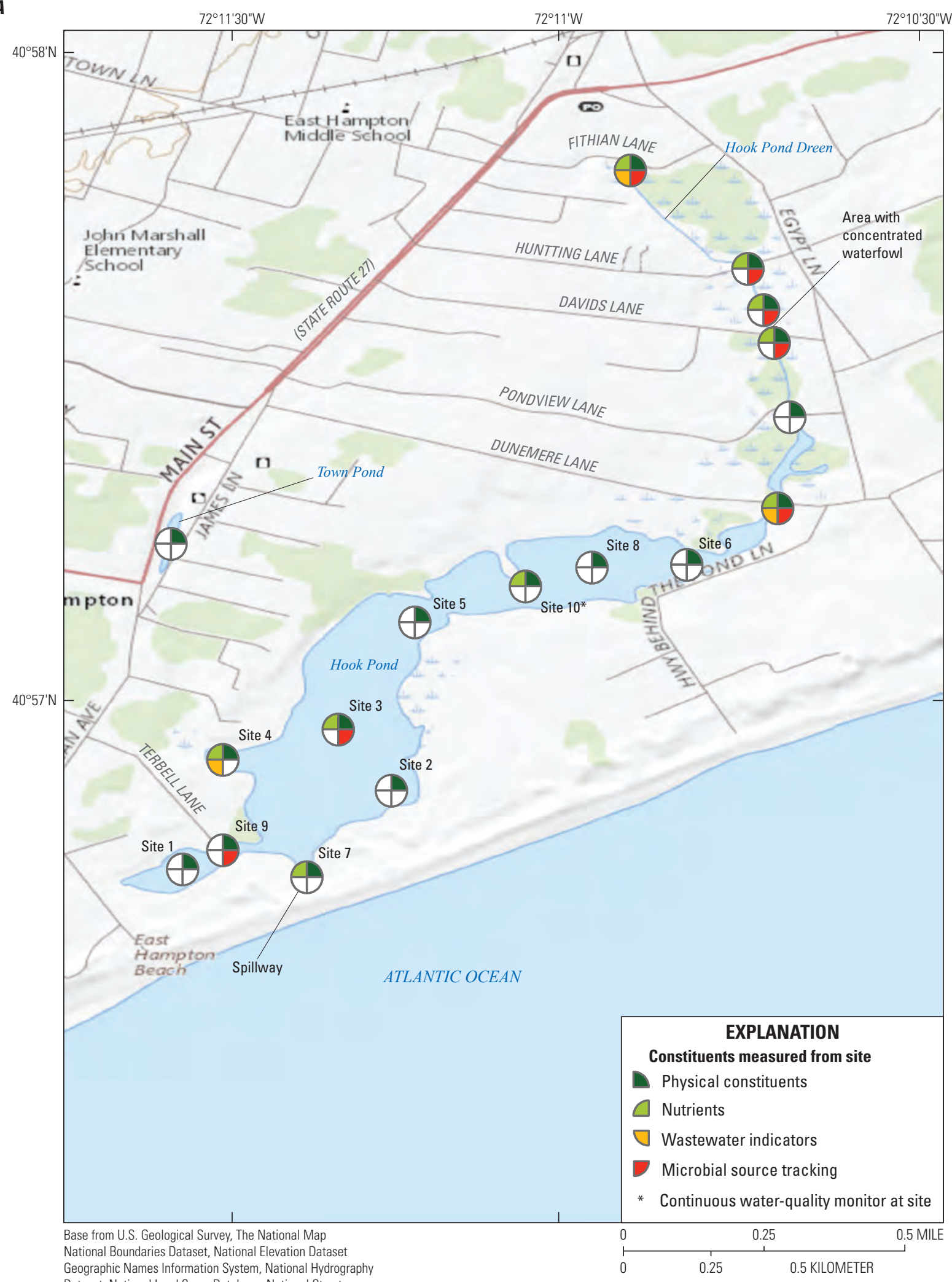

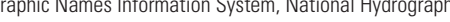

Dataset, National Land Cover Database, National Structures

Dataset, and National Transportation Dataset

U.S. Census Bureau — TIGER/Line; HERE Road Data

Figure 4. Hook Pond and Hook Pond Dreen sites in East Hampton, New York, where $A$, surface-water and $B$, groundwater samples were collected. 
B

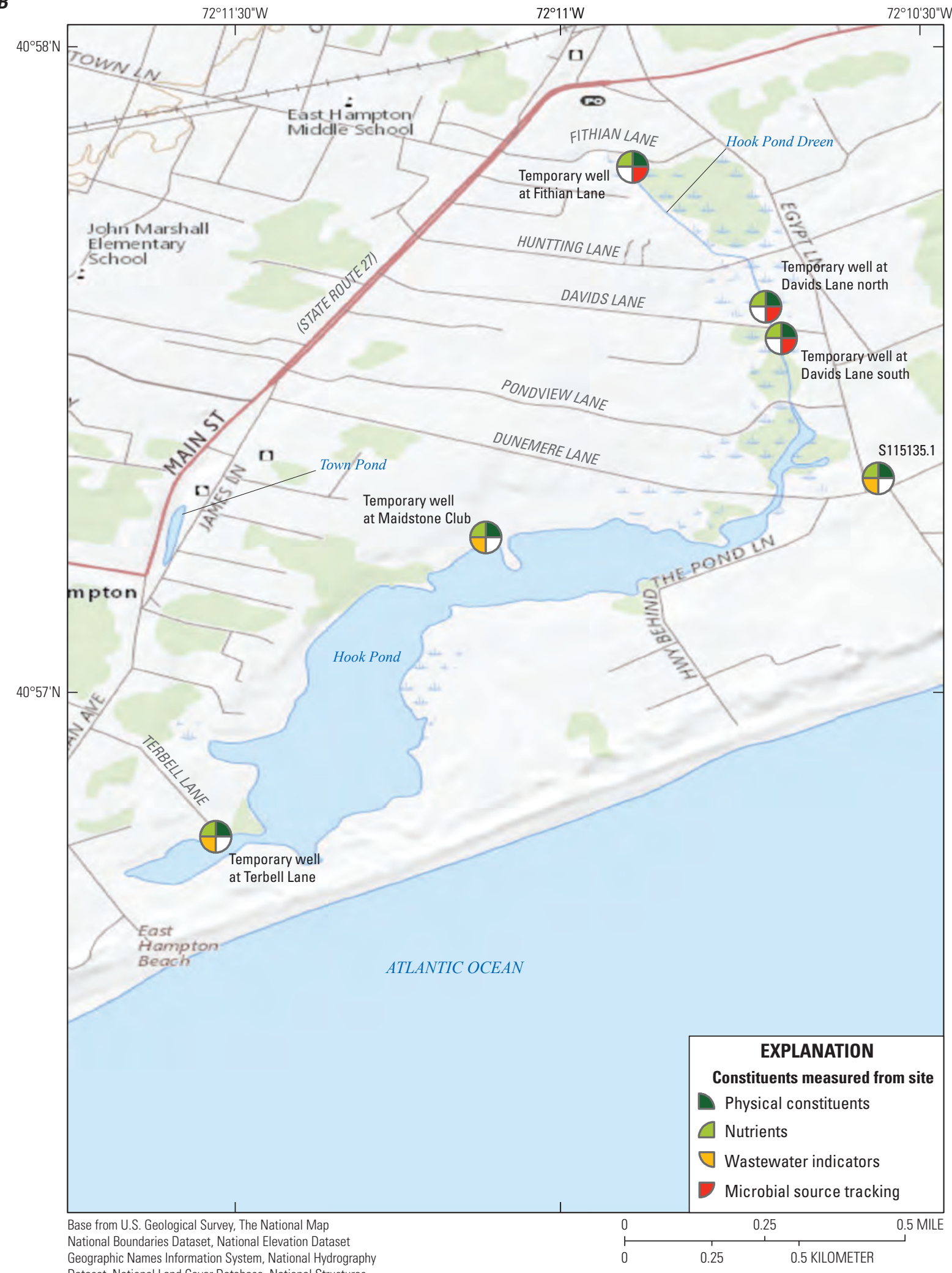

Dataset, and National Transportation Dataset

U.S. Census Bureau—TIGER/Line; HERE Road Data

Figure 4. - Continued 
depth-profile data, can help identify an effective location for future water-quality monitoring and track potential filling or shallowing of the pond through time. Water-quality data from this assessment can be used by the Village of East Hampton and other stakeholders to better understand sources of nutrients and measures of ecological health for Hook Pond. In a broader sense, this study can provide resource managers with information to help protect groundwater and surface-water resources of coastal communities throughout Suffolk County.

This report (1) describes the monitoring of water quality and potential sources of fecal contamination of Hook Pond and surrounding areas and the methods of data collection and analysis, (2) presents an assessment of the water-quality conditions of Hook Pond and Hook Pond Dreen from a spatial and temporal perspective, and (3) provides information necessary for making decisions about mitigating nutrient and fecal contamination loading to Hook Pond, as well as providing a baseline for any future mitigation. Data generated or collected during this study are available in tables within this report and from the USGS National Water Information System (NWIS) database (USGS, 2020a). Historical data collected by the USGS from 2001-8 also are available from the NWIS database (USGS, 2020b).

\section{Methods}

The following subsections detail methods of site selection and access, field measurement, laboratory analysis, quality assurance, and the use of ancillary data.

\section{Site Selection and Access}

Sampling sites in and along Hook Pond, Hook Pond Dreen, and Town Pond were selected at various points to ensure representative spatial coverage (fig. 4). Physicochemical constituents were measured as depth profiles at nine locations throughout Hook Pond, and single-depth physicochemical constituents were measured at sites along Hook Pond Dreen and at one point along the eastern shoreline of Town Pond (fig. 4A; table 1). When collecting physicochemical constituents at Hook Pond, field personnel navigated by boat as close as possible to the surface-water sites shown in figure $4 A$ and recorded global positioning system (GPS) coordinates (referenced to the North American Datum of 1983 [NAD 83]) to document where measurements were made. Sites along Hook Pond Dreen were accessed by vehicle, and samples were collected at the same location each visit (on the south side of the road past the culvert). At the sites along Hook Pond Dreen, physicochemical constituents were collected as single point samples, typically at 0.5 foot (ft) below the water surface, instead of being measured as multidepth profiles because of the shallow depth of the tributary, and parameters did not differ across the stream width at each site (periodic cross-section measurements were observed but not recorded).

\section{Field Methods}

To assess water-quality conditions of Hook Pond throughout an entire calendar year, multiple field methods were employed. A continuous water-quality monitor was deployed for a 1-year period to assess real-time changes every 15 minutes at Hook Pond site 10. Depth profiles throughout the pond were collected every 2-4 weeks (except during periods when the pond surface was frozen) for 1 year to document changes in physicochemical constituents and determine how well the continuous monitoring station correlated with data from Hook Pond sites 1-10. Water-quality samples were collected at sites 3, 4, 7, and 10 in Hook Pond, with a focus on the center of the lower part of the pond (site 3), to improve understanding of nutrient concentrations throughout the pond. For the purposes of this study, dates corresponding to the 2017-18 astronomical seasons were used: June 21September 22, summer; September 23-December 20, autumn; December 21-March 19, winter; and March 20-June 20, spring. Stream discharge measurements were also collected along Hook Pond Dreen to help determine which portions of the dreen were gaining groundwater and which may have been losing surface water to the unsaturated soils along the banks.

\section{Continuous Water-Quality Monitoring}

The Aqua TROLL 200 (In-Situ, Inc.) continuous waterquality monitor was used to continuously collect specific conductance, water temperature, and pond water-surface elevation data at Hook Pond site 10 from the Maidstone Club golf cart bridge that crosses the northern part of the pond from August 9, 2017, to August 2, 2018. The monitor was serviced routinely every 4 weeks in the summer, 6 weeks in the spring and fall, and 8 weeks in the winter, with fouling and calibration checks performed during each visit—all servicing was performed in accordance with Wagner and others (2006). Measurements of water temperature and specific conductance were always within the manufacturer's accuracy range. Elevations are reported in relation to the National Geodetic Vertical Datum of 1929 (NGVD 29) in the USGS National Water Information System, but for comparison to ancillary data used in this report, they have been converted to North American Vertical Datum of 1988 (NAVD 88) values by subtracting $0.932 \mathrm{ft}$, a difference derived from the National Oceanic and Atmospheric Administration (NOAA) VERTCON program (NOAA, 2019) using the latitude and longitude of Hook Pond. The elevation of the pond is controlled by a passive spillway (figs. 2 and $3 A$ ) at the south end of the pond, which allows discharge of water that exceeds an elevation $2.7 \mathrm{ft}$ above NGVD 29 (Lombardo Associates, Inc., 2015) to the Atlantic Ocean through underground piping. 
Table 1. Site name, location, and type of sample collected at each site within the Hook Pond watershed, East Hampton, New York.

[Latitude and longitude are referenced to the North American Datum of 1983 and are accurate to the nearest 1 second. Median lakebed elevation at each site within Hook Pond was determined by calculating the difference between the median depth-to-bottom measurement and the corresponding water-surface elevation (from the continuous water-quality monitor at Hook Pond site 10). Latitude and longitude are in degrees $\left({ }^{\circ}\right)$, minutes $(')$, and seconds ("). USGS, U.S. Geological Survey ft, foot; NAVD 88, North American Vertical Datum of 1988; D, depth profile of physicochemical constituents; N, nutrients; I, stable isotopes; M, microbial source tracking; W, wastewater indicators; P, point measurement of physicochemical constituents; - , not measured; NA, not applicable]

\begin{tabular}{|c|c|c|c|c|c|c|}
\hline Site name & USGS station identifier & Latitude & Longitude & Samples collected & $\begin{array}{l}\text { Median depth } \\
\text { to bottom (ft) }\end{array}$ & $\begin{array}{l}\text { Median lakebed } \\
\text { elevation (ft } \\
\text { above NAVD 88) }\end{array}$ \\
\hline \multicolumn{7}{|c|}{ Hook Pond } \\
\hline Hook Pond (site 1) & 405644072113601 & $\mathrm{~N} 40^{\circ} 56^{\prime} 44.4^{\prime \prime}$ & $\mathrm{W} 72^{\circ} 11^{\prime} 35.6^{\prime \prime}$ & $\mathrm{D}$ & 1.43 & 1.60 \\
\hline Hook Pond (site 2) & 405652072111501 & $\mathrm{~N} 40^{\circ} 56^{\prime} 52.3^{\prime \prime}$ & $\mathrm{W} 72^{\circ} 11^{\prime} 15.4^{\prime \prime}$ & $\mathrm{D}$ & 3.59 & -0.38 \\
\hline Hook Pond (site 3 ) & 0130469550 & $\mathrm{~N} 40^{\circ} 56^{\prime} 56.2^{\prime \prime}$ & $\mathrm{W} 72^{\circ} 11^{\prime} 20.5^{\prime \prime}$ & $\mathrm{D}, \mathrm{N}, \mathrm{I}, \mathrm{M}$ & 3.70 & -0.60 \\
\hline Hook Pond (site 4) & 405656072113301 & $\mathrm{~N} 40^{\circ} 56^{\prime} 55.8^{\prime \prime}$ & $\mathrm{W} 72^{\circ} 11^{\prime} 33.0^{\prime \prime}$ & $\mathrm{D}, \mathrm{N}, \mathrm{I}, \mathrm{W}$ & 2.59 & 0.33 \\
\hline Hook Pond (site 5) & 405708072111401 & $\mathrm{~N} 40^{\circ} 57^{\prime} 08.3^{\prime \prime}$ & $\mathrm{W} 72^{\circ} 11^{\prime} 14.4^{\prime \prime}$ & $\mathrm{D}$ & 2.50 & 0.45 \\
\hline Hook Pond (site 6) & 405714072104801 & $\mathrm{~N} 40^{\circ} 57^{\prime} 13.5^{\prime \prime}$ & $\mathrm{W} 72^{\circ} 10^{\prime} 47.7^{\prime \prime}$ & $\mathrm{D}$ & 1.84 & 1.18 \\
\hline Hook Pond (site 7) & 0130469575 & $\mathrm{~N} 40^{\circ} 56^{\prime} 43.7^{\prime \prime}$ & $\mathrm{W} 72^{\circ} 11^{\prime} 24.0^{\prime \prime}$ & $\mathrm{D}, \mathrm{N}$ & 2.80 & 0.20 \\
\hline Hook Pond (site 8) & 405713072105801 & $\mathrm{~N} 40^{\circ} 56^{\prime} 12.9^{\prime \prime}$ & $\mathrm{W} 72^{\circ} 10^{\prime} 58.4^{\prime \prime}$ & $\mathrm{D}$ & 2.20 & 0.80 \\
\hline Hook Pond (site 9) & 405647072113201 & $\mathrm{~N} 40^{\circ} 56^{\prime} 47.0^{\prime \prime}$ & $\mathrm{W} 72^{\circ} 11^{\prime} 31.6^{\prime \prime}$ & $\mathrm{P}, \mathrm{M}$ & - & - \\
\hline Hook Pond (site 10$)^{1}$ & 0130469525 & $\mathrm{~N} 40^{\circ} 57^{\prime} 11.0^{\prime \prime}$ & $\mathrm{W} 72^{\circ} 11^{\prime} 04.0^{\prime \prime}$ & $\mathrm{D}, \mathrm{N}$ & 2.80 & 0.18 \\
\hline \multicolumn{7}{|c|}{ Hook Pond Dreen } \\
\hline Fithian Lane & 405750072105401 & $\mathrm{~N} 40^{\circ} 57^{\prime} 49.5^{\prime \prime}$ & $\mathrm{W} 72^{\circ} 10^{\prime} 53.8^{\prime \prime}$ & $\mathrm{P}, \mathrm{N}, \mathrm{I}, \mathrm{W}, \mathrm{M}$ & - & - \\
\hline Huntting Lane & 405740072104301 & $\mathrm{~N} 40^{\circ} 57^{\prime} 40.1^{\prime \prime}$ & $\mathrm{W} 72^{\circ} 10^{\prime} 42.6^{\prime \prime}$ & $\mathrm{P}, \mathrm{N}, \mathrm{I}, \mathrm{M}$ & - & - \\
\hline Davids Lane (north) & 405736072104101 & $\mathrm{~N} 40^{\circ} 57^{\prime} 36.0^{\prime \prime}$ & $\mathrm{W} 72^{\circ} 10^{\prime} 41.0^{\prime \prime}$ & $\mathrm{P}, \mathrm{N}, \mathrm{I}, \mathrm{M}$ & - & - \\
\hline Davids Lane (south) & 01304693 & $\mathrm{~N} 40^{\circ} 57^{\prime} 33.8^{\prime \prime}$ & $\mathrm{W} 72^{\circ} 10^{\prime} 40.3^{\prime \prime}$ & $\mathrm{P}, \mathrm{N}, \mathrm{I}, \mathrm{M}$ & - & - \\
\hline Pondview Lane & 405727072103901 & $\mathrm{~N} 40^{\circ} 57^{\prime} 27.0^{\prime \prime}$ & $\mathrm{W} 72^{\circ} 10^{\prime} 38.8^{\prime \prime}$ & $\mathrm{P}$ & - & - \\
\hline Dunemere Lane & 01304695 & $\mathrm{~N} 40^{\circ} 57^{\prime} 18.3^{\prime \prime}$ & $\mathrm{W} 72^{\circ} 10^{\prime} 42.3^{\prime \prime}$ & $\mathrm{P}, \mathrm{N}, \mathrm{W}, \mathrm{M}$ & - & - \\
\hline \multicolumn{7}{|c|}{ Groundwater } \\
\hline Temporary well at Fithian Lane & 405750072105301 & $\mathrm{~N} 40^{\circ} 57^{\prime} 50.0^{\prime \prime}$ & $\mathrm{W} 72^{\circ} 10^{\prime} 53.0^{\prime \prime}$ & $\mathrm{P}, \mathrm{N}, \mathrm{I}, \mathrm{M}$ & NA & NA \\
\hline S115135.1 & 405720072103001 & $\mathrm{~N} 40^{\circ} 57^{\prime} 20.0^{\prime \prime}$ & $\mathrm{W} 72^{\circ} 10^{\prime} 30.0^{\prime \prime}$ & $\mathrm{P}, \mathrm{N}, \mathrm{W}$ & NA & NA \\
\hline Temporary well at end of Terbell Lane & 405647072113301 & $\mathrm{~N} 40^{\circ} 56^{\prime} 47.0^{\prime \prime}$ & $\mathrm{W} 72^{\circ} 11^{\prime} 33.0^{\prime \prime}$ & $\mathrm{P}, \mathrm{N}, \mathrm{W}$ & NA & NA \\
\hline Temporary well $01-$ Maidstone Club & 405715072110701 & $\mathrm{~N} 40^{\circ} 57^{\prime} 15.0^{\prime \prime}$ & $\mathrm{W} 72^{\circ} 11^{\prime} 07.0^{\prime \prime}$ & $\mathrm{P}, \mathrm{N}, \mathrm{I}, \mathrm{W}$ & NA & NA \\
\hline Temporary well at Davids Lane (south) & 405734072104001 & $\mathrm{~N} 40^{\circ} 57^{\prime} 34.0^{\prime \prime}$ & $\mathrm{W} 72^{\circ} 10^{\prime} 40.0^{\prime \prime}$ & $\mathrm{P}, \mathrm{N}, \mathrm{I}, \mathrm{M}$ & NA & NA \\
\hline Temporary well near Davids Lane (north) & 405736072104001 & $\mathrm{~N} 40^{\circ} 57^{\prime} 36.0^{\prime \prime}$ & $\mathrm{W} 72^{\circ} 10^{\prime} 40.0^{\prime \prime}$ & $\mathrm{P}, \mathrm{N}, \mathrm{I}, \mathrm{M}$ & NA & NA \\
\hline \multicolumn{7}{|c|}{ Town Pond } \\
\hline Town Pond & 405715072113601 & $\mathrm{~N} 40^{\circ} 57^{\prime} 14.7^{\prime \prime}$ & $\mathrm{W} 72^{\circ} 11^{\prime} 35.7^{\prime \prime}$ & $\mathrm{P}$ & - & - \\
\hline
\end{tabular}

${ }^{1}$ Site with continuous water-quality monitor. 


\section{Depth Profiles}

Depth-profile data were collected by using a steel tape, Secchi disk, and a YSI EXO2 multiparameter sonde (YSI Inc.) to measure water temperature, $\mathrm{pH}$, specific conductance, dissolved oxygen, turbidity, and total algae pigment (chlorophyll $a$ and phycocyanin) fluorescence. Concentrations of chlorophyll $a$ and phycocyanin are based on measurements of optical properties of biochemicals associated with algae and are thus measures of relative fluorescence, which may not be indicative of true chlorophyll $a$ and phycocyanin concentrations that would be determined by laboratory analysis of a water sample. However, the relative differences in concentrations collected for this study are useful for understanding changes throughout the year in phytoplankton activity. Secchi depth was recorded in feet, and measurements were collected according to the USGS National Field Manual for the Collection of WaterQuality Data (USGS, variously dated). Depth to bottom at each site was determined by using a steel tape with a weighted end and a Secchi disk (to prevent the weight from sinking into muddy bed sediment) measured to the water surface. Instruments were calibrated for each constituent according to the USGS National Field Manual (USGS, 2008), the instrument manual, or both.

Profiles were collected late morning through early afternoon, and a sample trip was typically completed within 3 hours for the first half of the study and 2 hours for the second half. For the first half of the study, depths in increments of $0.5 \mathrm{ft}$ were assessed for physicochemical constituents until it was determined after several months that there was no substantial difference in depth at a given site, likely because of the shallow depths, which were not greater than $(>) 5 \mathrm{ft}$ at sites measured for this study. During the second half of the study, physicochemical constituents were assessed at three depths within the water column - just below the surface, the middle of the water column, and just above the bottom. Initially, nine depth-profile sites (sites 1-8 and 10) were selected throughout Hook Pond for a full spatial representation (table 1); however, the number of sites visited was reduced because little spatial variation in the values of physical constituents was observed (sites 2, 6, 7, and 9 were not monitored for depth profiles in 2018). Site 10, which is directly adjacent to the continuous monitoring location, was also used to ensure values collected at the continuous water-quality monitoring site matched the values outside the steel pipe that enclosed the continuous monitor (fig. 5).

\section{Water-Quality and Microbiological Sample Collection}

Water-quality samples for inorganic species of nitrogen and phosphorus were collected at Hook Pond sites 3, 4, 7, and 10 throughout the study, with a focus on site 3 (fig. $4 A$ ). Samples in Hook Pond Dreen were collected on an event basis (that is, snowmelt, storm, nonstorm). In Hook Pond and along

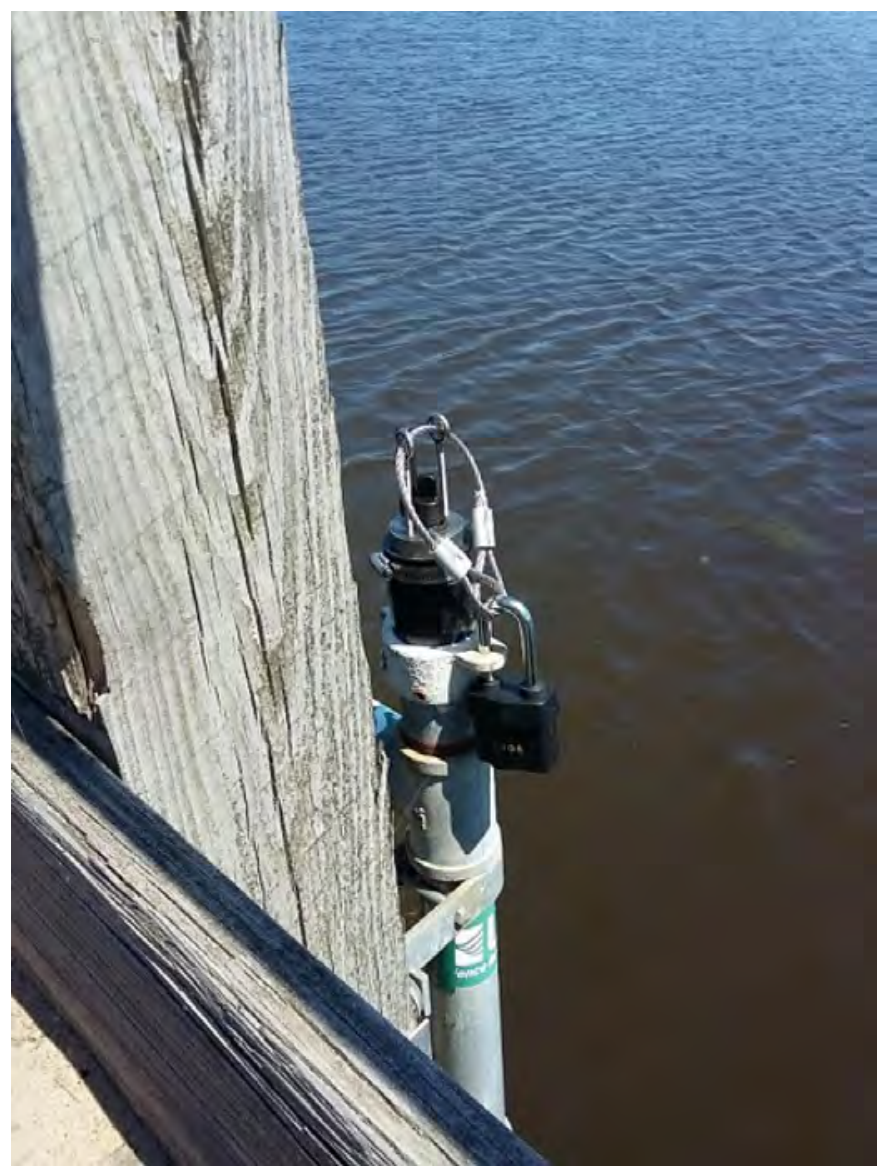

Figure 5. Hook Pond site 10-continuous water-quality monitor inside a steel pipe secured to a piling on the north side of the Maidstone Club golf cart bridge, East Hampton, New York. Photograph by Shawn C. Fisher, U.S. Geological Survey.

Hook Pond Dreen, samples were collected by using a DH-81 sampler with a 1-liter (L) Teflon bottle to collect a point sample at middle-depth of the water column. Once collected, either samples were processed immediately or the Teflon bottle was placed on ice in a cooler for processing back on shore (within 15 minutes of collection). Samples were processed for analysis in accordance with the USGS National Field Manual (USGS, variously dated) and the appropriate analytical method (Fishman, 1993). Surface-water samples for unfiltered (that is, whole water) constituents were preserved with sulfuric acid to limit biological degradation. Filtered samples of surface water and groundwater were passed through a 0.45 -micrometer $(\mu \mathrm{m})$ capsule filter to remove most bacteria and sediment.

Wet-weather (or storm) samples were collected to characterize changes in influxes during storm conditions. Storm samples were analyzed for wastewater compounds, fecal coliforms, MST markers, and coliphages (fig. 4A). Samples were collected at Dunemere Lane and Hook Pond site 4 during a spring storm and at Fithian Lane and Dunemere Lane during a summer storm to help characterize runoff that enters Hook Pond during a rain event. Spring storm samples were collected between 2 and 4 hours after the rain events ended, and these 
events represented 0.6 inch of total precipitation according to East Hampton Airport (KHTO; fig. 1) weather data. The summer sample at Fithian Lane was collected during the first flush of the system for the rain event, when water from the storm sewer outfall changed in color and odor; the Dunemere Lane sample was collected approximately 1 hour later. Samples were collected for nutrients and wastewater-indicator compounds. Samples for wastewater indicators were prepared by filtering water into a $1-\mathrm{L}$ amber glass bottle through a $0.7-\mu \mathrm{m}$ glass fiber filter. After processing, nutrient and wastewaterindicator compound samples were put on ice and shipped to the USGS National Water Quality Laboratory (NWQL) in Denver, Colorado, for analysis.

Samples for isotopes of nitrogen and oxygen in nitrate, or nitrogen in ammonium, were processed according to Coplen and others (2012) and Hannon and Böhlke (2008), respectively. Because most samples collected were oxic, sufficient concentrations of nitrate for oxygen and nitrogen isotope analyses were assumed present (and later confirmed); thus waters for isotope analysis were passed through a $0.45-\mu \mathrm{m}$ and a $0.2-\mu \mathrm{m}$ syringe filter into a $125-\mathrm{mL}$ amber polyethylene bottle with a conical polyseal cap and were frozen to prevent biological reactions of nitrogen-bearing species. In two groundwater samples with dissolved oxygen less than $(<)$ $1.0 \mathrm{mg} / \mathrm{L}$, a $1-\mathrm{L}$ bottle was filled directly and preserved with sulfuric acid to limit biological degradation. All isotope samples were held until corresponding nutrient data were available from the NWQL. Samples with nitrate concentrations of at least $0.06 \mathrm{mg} / \mathrm{L}$ as nitrogen or ammonia concentrations of at least $0.2 \mathrm{mg} / \mathrm{L}$ as nitrogen were shipped on ice to the USGS Reston Stable Isotope Laboratory in Reston, Virginia, for isotope analysis.

Samples collected for indicator bacteria analyses were filled directly from the source, except for groundwater samples, which were pumped through a peristaltic pump. Procedures outlined in the USGS National Field Manual (USGS, variously dated) for proper collection were followed, and equipment was sanitized by using ethanol and bleach wipes and was rinsed thoroughly with deionized water prior to use (Fisher and others, 2015). Three 100-mL sterile polystyrene bottles were used for fecal indicator bacteria, one sterile 500-mL polyethylene bottle was used for MST markers, and one 1-L sterile polystyrene bottle was used for coliphage samples.

\section{Stream Discharge Measurements}

Stream discharge measurements were collected along Hook Pond Dreen at Fithian Lane, Huntting Lane, Davids Lane (south), and Pondview Lane (fig. 4) on May 31, 2018, to help determine relative contributions of groundwater between the culverts at Fithian Lane and Pondview Lane, which acts as a considerable source of stormwater to Hook Pond. Measurements were made by wading in the stream channel and using a SonTek (San Diego, California) FlowTracker acoustic Doppler velocimeter following guidelines in
Turnipseed and Sauer (2010). Measurement locations were chosen where the stream channel was reasonably straight, with laminar flow, and deep enough (using the 0.6-depth method) for the velocimeter. The upper reaches of the stream channel were narrow, limiting the number of sections recorded, with the smallest amounts being 9 vertical sections at Fithian Lane and 24 vertical sections at Pondview Lane.

\section{Laboratory Methods}

Water samples for chemical analysis (nutrients and wastewater-indicator compounds) were shipped on ice overnight to the USGS NWQL in Denver, Colo. Isotope samples were stored frozen $\left(-20\right.$ degrees Celsius $\left.\left[{ }^{\circ} \mathrm{C}\right]\right)$ at the USGS New York Water Science Center Coram office until all nitrate and ammonium concentrations were available from the NWQL, at which time the samples were shipped together on ice overnight to the USGS Reston Stable Isotope Laboratory in Reston, Va. Samples collected for fecal indicator bacteria were delivered to the Suffolk County Department of Health Services' Public and Environmental Health Laboratory (PEHL; Hauppauge, N.Y.) within 6 hours of collection. Samples for MST markers and coliphages were shipped on ice overnight to the USGS Ohio Water Microbiological Laboratory (OWML; Columbus, Ohio) and the USGS Environmental and Public Health Microbiology Laboratory (St. Petersburg, Florida), respectively.

\section{Nutrient Analysis}

Two analytical methods were used, depending on medium, for determining inorganic and total organic nitrogen species of nitrogen and phosphorus: National Water Quality Laboratory laboratory schedule 2702 for surfacewater samples and laboratory schedule 2755 for groundwater samples (Fishman, 1993; Patton and Kryskalla, 2011; Patton and Truitt, 2000). Concentrations of ammonia (ammonia plus ammonium), nitrite, nitrate, ammonia plus organic nitrogen, orthophosphorus, and total phosphorus were measured in filtered samples. Concentrations of ammonia plus organic nitrogen and total phosphorus were also measured in unfiltered samples. Total nitrogen was determined by summing concentrations of ammonia plus organic nitrogen (either filtered or unfiltered) and nitrate plus nitrite. A list of the compounds in this analytical method and the respective reporting limits are presented in appendix 1, table 1.1.

\section{Wastewater-Indicator Analysis}

Concentrations of 58 compounds typically associated with wastewater sources (such as stormwater runoff, OWDSs, pesticide use, and industrial processes) were assessed in filtered groundwater and surface waters by using National Water Quality Laboratory schedule 1433 (Zaugg and others, 2002). Classes of the compounds include surfactants and their 
degradates, food additives, fragrances, antioxidants, flame retardants, plasticizers, industrial solvents, disinfectants, fecal sterols, polycyclic aromatic hydrocarbons, and high-use pesticides. Reporting limits for this method range from 0.01 to 4.0 micrograms per liter $(\mu \mathrm{g} / \mathrm{L})$ during the period of this study. Surrogate spikes for recovery, sample set blanks, and other controls are routinely performed by the NWQL and meet quality-assurance standards. Surrogate percent recovery data are presented along with wastewater-indicator data in the report section "Spatiotemporal Assessment of Nutrients and Wastewater-Indicator Compounds in the Hook Pond Watershed." A list of the compounds in this analytical method and their respective reporting limits are presented in appendix table 1.1.

\section{Nitrogen Isotope Analysis}

Stable isotope analyses for nitrate and ammonium were conducted to help estimate the relative sources of inorganic nitrogen in groundwater and surface waters within the Hook Pond watershed, such as fertilizers, pet waste, and OWDSs in the shallow nearshore aquifer (Abbene, 2010; Colman and others, 2018). Select samples were submitted to the USGS Reston Stable Isotope Laboratory for analysis. Results from laboratory code 2900 for delta nitrogen- $15\left(\delta^{15} \mathrm{~N}\right)$ and delta oxygen-18 $\left(\delta^{18} \mathrm{O}\right)$ of nitrate (Coplen and others, 2012) and laboratory code 2898 for $\delta^{15} \mathrm{~N}$ of ammonium (Hannon and Böhlke, 2008) are presented in per mil (or parts per thousand), which is the difference in the ratios of ${ }^{15} \mathrm{~N}$ to ${ }^{14} \mathrm{~N}$ and ${ }^{18} \mathrm{O}$ to $16 \mathrm{O}$ relative to atmospheric nitrogen or another standard ratios and normalized to the same standard ratio. By plotting $\delta 18 \mathrm{O}$ in relation to $\delta^{15} \mathrm{~N}$, and $\delta^{15} \mathrm{~N}$ in relation to nitrate concentration, information can be gleaned related to sources of nitrogen and processes that forms of nitrogen undergo (for example, groundwater with $\delta^{15} \mathrm{~N}$ of 10 per mil and $\delta^{18} \mathrm{O}$ of 5 per mil may be indicative of nitrate from wastewater, and stream water with $\delta^{15} \mathrm{~N}$ of 0 per mil and $\delta^{18} \mathrm{O}$ of 40 per mil indicates the mixing of stream and precipitation [Burns and others, 2009]). Reference standards are run with each batch for determining ratios of the stable isotope by mass. Laboratory method performance procedures and quality assurance procedures are documented in Coplen and others (2012) and Hannon and Böhlke (2008).

\section{Microbiological Analyses}

Assays for $\mathrm{F}^{+}$-specific coliphages were prepared on the same day when samples were received at the USGS St. Petersburg microbiology laboratory. Details of the laboratory procedures are provided in appendix 1 . In summary, sample aliquots were plated (single layer overlay) in triplicate using E. coli $\mathrm{F}_{\text {amp }}$ as a host, incubated overnight at $36.5^{\circ} \mathrm{C}$, and counted the following day. Plates were either positive or negative for the presence of $E$. coli-indicating the presence of coliphages - and both positive and negative controls were also prepared with each sample set. For the enrichment assays, the remaining volume of the 1-L sample was spiked with E. coli $\mathrm{F}_{\mathrm{amp}}$ and 30 grams of trypticane soy broth and incubated overnight at $36.5^{\circ} \mathrm{C}$, and any sample resulting in a plaqued spot check was transferred to a sterile $50-\mathrm{mL}$ tube and frozen at $-20^{\circ} \mathrm{C}$ until RNA was extracted. Once extracted, presence or absence was evaluated with the reverse transcriptase-polymerase chain reaction and conducted in duplicate for each $\mathrm{F}^{+}$-specific coliphage group (I, II, III, and IV) by using $2 \mu \mathrm{L}$ of template per reaction. Primer and probe sequences were referenced to previously published sequences (Wolf and others, 2008). Reactions were deemed positive if exponential amplification was noted in both duplicate reactions prior to 30 cycles. Markers of each group identify the following origins: group I, animal; group II, human or swine; III, human; IV, animal (birds) (Griffin and others, 2000). Field and laboratory blanks were run to ensure no outside contamination was introduced during the collection and analysis process; no detections in blanks were observed. Synthetic gene fragments were used for positive control reactions; all positive control reactions produced a positive result.

Samples submitted to the USGS OWML for Bacteroides analysis were processed according to established protocols for each marker (see appendix 1 for more details). In summary, all samples were filtered through a $0.4-\mu \mathrm{m}$ pore-size polycarbonate filter the day after collection, and the filters were placed in vials containing acid-washed glass beads and preserved at $-70{ }^{\circ} \mathrm{C}$. Based on results of the coliphage analyses, DNA extraction on a subset of sample filters was conducted and analyzed by the quantitative polymerase chain reaction (qPCR) method. Assays for each MST marker were performed according to protocols based on their respective references: BacCan, canine-associated Bacteroides marker (Kildare and others, 2007); GFD, waterfowl-associated Helicobacter marker (Green and others, 2012); HF183, human-associated Bacteroides marker (Seurinck and others, 2005); and Rum2Bac, ruminant-associated Bacteroides marker (Mieszkin and others, 2009). Field and laboratory blanks were analyzed to identify potential sources of outside contamination introduced during the collection and analysis process. Results from field blanks were negative for all markers. In one sample set, an inlaboratory contamination event likely occurred for one of the field blanks; spare sample filters were analyzed, and data were adjusted and qualified accordingly (see appendix 1 for details).

Known-source samples collected for human (influent from Sag Harbor sewage treatment plant), waterfowl (feces collected adjacent to Hook Pond Dreen at Davids Lane), and deer (feces collected in Orient, N.Y.) were used for comparison to coliphage and MST marker results. Results from the influent sample show strong human presence (coliphages and MST marker HF183), as well as the canine marker Bac-

Can, which is attributed to the link between humans and the domestic dog (Bushon and others, 2017). Although coliphage results were negative for waterfowl and deer feces, the respective MST markers GFD and Rum2Bac were the only markers detected for these known-source samples. 
Samples for fecal indicator bacteria were processed at the PEHL within 6 hours of collection. Depending on the method, growth media was either added directly to the $100 \mathrm{~mL}$, poured into incubation trays, and incubated overnight or filtered through a membrane, plated, and incubated overnight. Methods performed are standard for recreational safety and public health: EPA methods SM 9221C, E-2006 (total coliforms); SM 9221B-2006 (fecal coliforms); SM 9223B-04 (E. coli); and 1600 (enterococci). The method reporting limits were 20 colonies (reported in most probable number [MPN] of colonies) per $100 \mathrm{~mL}$ (MPN/100 mL) for total coliform and fecal coliform, $1 \mathrm{MPN} / 100 \mathrm{~mL}$ for $E$. coli, and 4 colonies $/ 100 \mathrm{~mL}$ for enterococci. Samples for fecal indicator bacteria were processed without dilution; therefore, concentrations for some samples exceeded the maximum count limit and are designated as greater than the maximum method detection limit. Field and laboratory blanks were analyzed to ensure no outside contamination was introduced during collection and analysis. The PEHL maintains Environmental Laboratory Approval Program accreditation through the New York State Department of Health (Wadsworth, N.Y.) for the indicator bacteria methods used for this study.

\section{Quality Assurance, Ancillary Data, and Interpretation}

Procedures outlined in the USGS National Field Manual for the Collection of Water-Quality Data (USGS, variously dated) for calibration of field equipment, proper handling of samples, and appropriate collection of quality-control samples were followed. Multiparameter sensors were checked against standards and calibrated as needed prior to each field trip. Samples were collected and processed to minimize introduction of contamination from the field equipment and personnel. Quality-control samples collected in the study, as well as other studies, throughout the 2017-18 season by using the same equipment and methods are presented along with respective data later in the report section "Water Quality of Hook Pond." Sequential replicate data for laboratory schedules 2702 and 2755 matched closely for filtered and unfiltered constituents, with the greatest deviation for unfiltered ammonium. Concentrations of all inorganic nitrogen and phosphorus species were below respective detection limits for equipment blanks on the Teflon-lined and peristaltic pump tubing and drive-point piezometer tip. There were no detections of coliphage markers or fecal indicator bacteria colonies, nor any field-related detections of MST markers, in any of the blank samples collected within the timeframe of this study.

Ancillary data used to help interpret continuous monitoring and discrete sampling data were compiled from various sources. Weather data captured at 20-minute intervals at East Hampton Airport (KHTO; fig. 1) from August 1, 2017, to August 31, 2018, were downloaded from the Iowa State University Environmental Mesonet network (Iowa State University, 2019). (Note that weather data are raw and not official National Weather Service data but are presumed satisfactory and thus presented in this study only for relative comparison to approved USGS data.) Tides data from the Montauk tide gage (NOAA station 8510560) were used for comparison with pond water-surface elevation data. Data from the USGS lake-level gage at Georgica Pond (USGS station 01304705) and upper glacial wells S8833.2 (USGS station 405756072173502, in Bridgehampton, N.Y.; daily data) and S8843.2 (USGS station 405906072110102, in East Hampton; monthly data) were related to Hook Pond water-surface elevation data to evaluate relative responsiveness to storm events and track changes relative to groundwater elevation (fig. 1). Groundwater elevations reported in the USGS National Water Information System database for wells S8833.2 and S8843.2 are relative to NGVD 29, and the datum was converted to NAVD 88 for this report by subtracting $0.922 \mathrm{ft}$ and $0.928 \mathrm{ft}$, respectively, from each value.

Summary statistics are presented for continuous and depth-profile data for spatial and seasonal comparisons. Plots of nitrate concentrations in the surface-water samples throughout the year are presented seasonally and spatially. Statistical significances of seasonality and sites were assessed with a one-way analysis of variance of rank (Helsel and Hirsh, 2002) and Tukey honestly significant difference test by using SigmaPlot 14 statistical software (by Systat Software, Inc.). Indicator bacteria (coliforms and enterococci) concentrations were correlated with detections of coliphages and MST markers to better understand frequency of occurrence relative to sources and weather.

\section{Water Quality of Hook Pond}

This study sought to provide the data necessary to develop a better understanding of the sources of nutrients and contaminants to Hook Pond by addressing several recommendations or data and monitoring gaps identified in the Hook Pond Water Quality Improvement Project (Lombardo Associates, Inc., 2015). Seasonal and spatial variability of Hook Pond water quality was evaluated to better inform management practices for controlling nutrients, pathogens, and other constituents associated with land use (such as those associated with OWDSs) and stormwater runoff.

Dry-weather discharge measurements along Hook Pond Dreen presented in table 2 indicate a gaining stream from Fithian Lane through to the culvert at Pondview Lane, with discharges ranging from 0.02 cubic foot per second $(\mathrm{ft} 3 / \mathrm{s})$ to $1.45 \mathrm{ft} 3 / \mathrm{s}$, respectively. These discharge values correspond to a water-table elevation of roughly $9.6 \mathrm{ft}$ above NAVD 88 at well S8843.2 and $15.3 \mathrm{ft}$ above NAVD 88 at well S8833.2 (both of which were measured on May 25, 2018). The increases in discharge correspond to increased groundwater contribution along the flowpath of Hook Pond Dreen, which may be proportional to the loading of nutrients seeping through the streambed. 
Table 2. Discharge values determined along Hook Pond Dreen at four U.S. Geological Survey stations in East Hampton, New York, on May 31, 2018.

[Fithian Lane represents the farthest upstream site in this study; sites are in order from upstream to downstream (see fig. 4). Measurements collected under normal, nonstorm conditions; USGS, U.S. Geological Survey; $\mathrm{ft} 3 / \mathrm{s}$, cubic foot per second]

\begin{tabular}{llc}
\hline \multicolumn{1}{c}{ Site name } & USGS station identifier & Discharge $(\mathbf{f t} \mathbf{3} / \mathbf{s})$ \\
\hline Fithian Lane & 405750072105401 & 0.02 \\
Huntting Lane & 405740072104301 & 0.55 \\
Davids Lane (south) & 01304693 & 0.70 \\
Pondview Lane & 405727072103901 & 1.5 \\
\hline
\end{tabular}

\section{Summary of Continuous Water-Quality Data}

Data for water temperature, specific conductance, and pond elevation collected throughout the study at 15 -minute intervals from Hook Pond site 10 (Maidstone Club golf cart bridge) are summarized in figures 6 and 7 and appendix 2 , table 2.1. Water temperature ranged from $19.2^{\circ} \mathrm{C}$ to $32.6{ }^{\circ} \mathrm{C}$ in the summer and reached below freezing $\left(-0.3^{\circ} \mathrm{C}\right)$ in the winter. Changes in air temperature (caused by daily diurnal cycles and passing storm fronts, for example) caused changes in water temperatures within 2-4 hours (except for when the pond surface was frozen beginning in late December 2017), as determined by comparison of water temperatures to weather data from East Hampton Airport station KHTO (fig. 6; appendix table 2.1).

Specific conductance at the gage was relatively stable throughout the year, with a median value of 339 microsiemens per centimeter at 25 degrees Celsius $\left(\mu \mathrm{S} / \mathrm{cm}\right.$ at $\left.25{ }^{\circ} \mathrm{C}\right)$ and a narrow range of values, with $292 \mu \mathrm{S} / \mathrm{cm}$ and $490 \mu \mathrm{S} / \mathrm{cm}$ representing the 10th and 90th percentiles. Weekly median values of specific conductance are listed in appendix table 2.1. In March 2018, specific conductance spiked above 10,000 $\mu \mathrm{S} / \mathrm{cm}$ following a series of snow and rain events (fig. 6). (Specific conductance values $>1,000 \mu \mathrm{S} / \mathrm{cm}$, the standard value at which the Aqua TROLL 200 was calibrated, are considered estimates for the purposes of interpretation.) These spikes are likely the result of a road salt pulse that entered Hook Pond Dreen at the Fithian Lane storm sewer outfall and progressed downstream to Hook Pond. The residual effect of road salt that passed by the gage lasted roughly 35 days (fig. 6) during a period of warming temperatures and thawing pond ice, after which specific conductance values returned to within the 10th and 90th percentiles.

Water-surface elevations throughout the study period ranged from 2.42 to $3.69 \mathrm{ft}$ above NAVD 88 and were generally responsive to large precipitation events throughout the year, though it is worth noting that the specific conductance values do not change substantially during most precipitation events in the summer months. Because the spillway regulates elevation, fluctuations in the pond generally reflect tidal influence on the shallow groundwater to which the pond is hydraulically connected. This influence is evident in the similarities between the NOAA tide data and the elevation of Hook Pond relative to Georgica Pond (fig. 7). Furthermore, relative to the elevation of the spillway $(1.77 \mathrm{ft}$ above NAVD 88 according to engineering reports presented in Lombardo Associates, Inc. [2015]), the Hook Pond elevation ranged from approximately 0.6 to $1.9 \mathrm{ft}$ above the spillway invert based on the continuous water-surface elevation data at the Hook Pond site 10. Interestingly, fluctuations in water-surface elevations in Hook Pond during this period suggest that tidal forces may have been influencing the pond-a cyclic, diurnal pattern between March 2 and 8, 2018, was observed coincident with a spring tide during that period (Montauk tide gage). This pattern was likely the result of elevated sea level forcing water to back up through the spillway (one-way gates on the spillway, which were designed to prohibit seawater from backing up into the pond during storms or higher-than-average tides were chained open at the time) and prevented the pond from fully discharging. The lack of a low tide on March 8 would have further prevented draining until the following day, when the tide receded and surface elevation in the pond rose from a combination of stalled draining and precipitation.

\section{Spatiotemporal Assessment of Physicochemical Constituents in the Hook Pond Watershed}

Results of the depth profiles of physicochemical constituents are presented seasonally by site (appendix tables 2.2 and 2.3 , fig. 8). Values for most constituents did not vary greatly across the pond or with depth for most profiles on a sample day, except for southwestern Hook Pond at site 1, which is somewhat isolated from the main flow from Hook Pond Dreen and the spillway (fig. 2). Measurements along Hook Pond Dreen and at Town Pond were collected at a single depth, typically $0.5 \mathrm{ft}$ below the surface where practical. Depths to bottom throughout Hook Pond (sites 1-8 and 10) were recorded during each field trip, with depths ranging from $0.5 \mathrm{ft}$ to $4.6 \mathrm{ft}$ below the water surface. The complete dataset, including constituent values for each site at each profile depth, as well as depth-to-bottom measurements, can be found on the USGS National Water Information System database (USGS, 2020b) by entering the corresponding station identifiers from table 1 .

Water temperatures across Hook Pond ranged from $1.6^{\circ} \mathrm{C}$ in the winter to $33.5^{\circ} \mathrm{C}$ in the summer (appendix tables 2.2 and 2.3). Water-temperature data collected at Hook Pond site 10 alongside the continuous monitor matched throughout the water column; values were within 5 percent of each other for 75 percent of the time (greater percentage differences occurred in the winter and autumn when temperatures were at or below $10^{\circ} \mathrm{C}$ ). Water temperatures recorded along Hook Pond Dreen varied and, in summer months, typically increased moving downstream; with lower values at Fithian Lane in the summer months, resulting from the contributions of groundwater (appendix tables 2.2-2.4). 


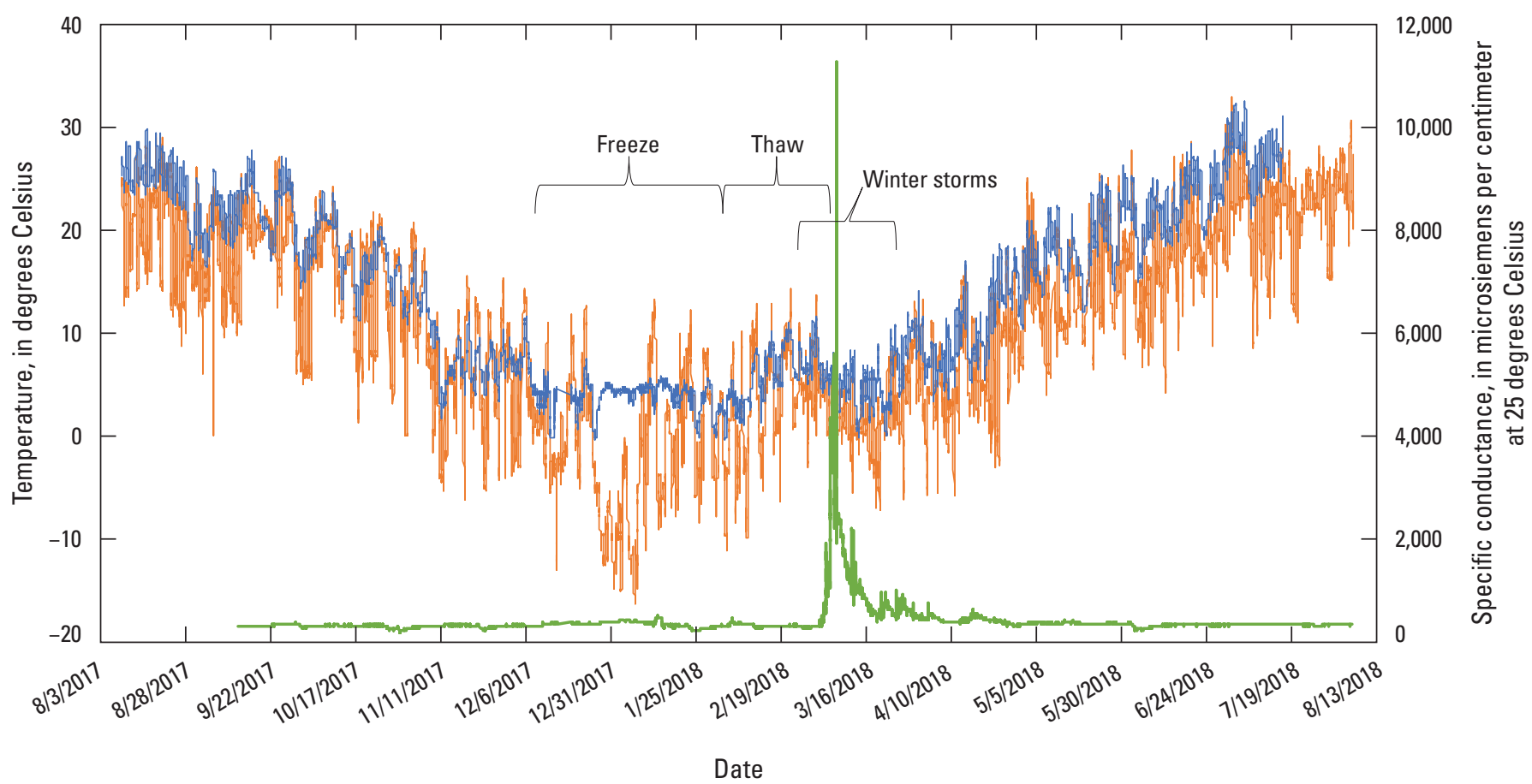

EXPLANATION

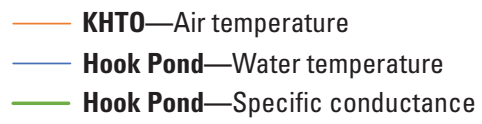

Figure 6. Continuous water-temperature and specific conductance data from Hook Pond site 10 (Maidstone Club golf cart bridge, East Hampton, New York) recorded at 15-minute intervals, and continuous air-temperature data from East Hampton Airport (KHTO) recorded at 20-minute intervals. Freeze range from late December 2017 to early February 2018; thaw ranged from early to late February 2018; winter storms occurred between February and March 2018.

Specific conductance remained relatively stable throughout Hook Pond and was within 5 percent of the continuous monitor for 90 percent of the time. The highest single value recorded in Hook Pond was 2,640 $\mu \mathrm{S} / \mathrm{cm}$ at the spillway (site 7) on March 15, 2018, which coincides with the road salt pulse moving through the pond (appendix tables 2.2 and 2.3). Specific conductance at Fithian Lane ranged from 618 to $1,080 \mu \mathrm{S} / \mathrm{cm}$ throughout the study, which relates to groundwater with lower specific conductance $(658 \mu \mathrm{S} / \mathrm{cm})$ during dry conditions and the greater conductivity of runoff conveyed through the storm sewers during storms and snowmelt (appendix tables 2.2 and 2.3). Values decreased downstream as the result of dilution by less conductive groundwater moving downstream from Fithian Lane (specific conductance of groundwater at temporary well at Davids Lane [south] was $325 \mu \mathrm{S} / \mathrm{cm})$.

The $\mathrm{pH}$ across Hook Pond ranged from 6.2 to 10 standard units (fig. 8), with the highest values recorded in the summer (appendix tables 2.2 and 2.3), likely resulting from algal activity similar to patterns observed in Mill Pond (Water Mill, N.Y.; USGS station 01304738) and described elsewhere (Dubinsky and Rotem, 1974). Values of $\mathrm{pH}$ along Hook Pond Dreen were between 6 and 7 units and were typically lower than in Hook
Pond on the same day. A weak correlation between $\mathrm{pH}$ and chlorophyll $a$ concentration was found when combining data from Hook Pond and Hook Pond Dreen, with lower values of each constituent the result of groundwater seepage, consistent flow, and more tree canopy creating shade along Hook Pond Dreen (appendix fig. 2.2). As with specific conductance, $\mathrm{pH}$ of the surface water in Hook Pond Dreen is similar to that of groundwater sampled at Fithian Lane but remains stable downstream (as it does in the groundwater sampled from both temporary wells at and near Davids Lane).

Dissolved oxygen concentrations throughout the water column were typically above $8 \mathrm{mg} / \mathrm{L}$ (with some measurements $>13 \mathrm{mg} / \mathrm{L}$ ) throughout the year (fig. 8; appendix tables 2.2 and 2.3) and were also consistent across the pond and with depth (to just above the sediment and water interface; interference from the probe guard of the multiparameter sonde disrupted the bed sediment when the sensors were $0.25 \mathrm{ft}$ above the bottom and thus likely distorted readings for dissolved oxygen measurements). These daytime measurements reflect well-mixed oxygenated water and, in cases of concentrations above $10 \mathrm{mg} / \mathrm{L}$, supersaturation indicative of algae growth. Concentrations of dissolved oxygen along Hook Pond Dreen, ranging from $4.6 \mathrm{mg} / \mathrm{L}$ to just under $10 \mathrm{mg} / \mathrm{L}$, were 


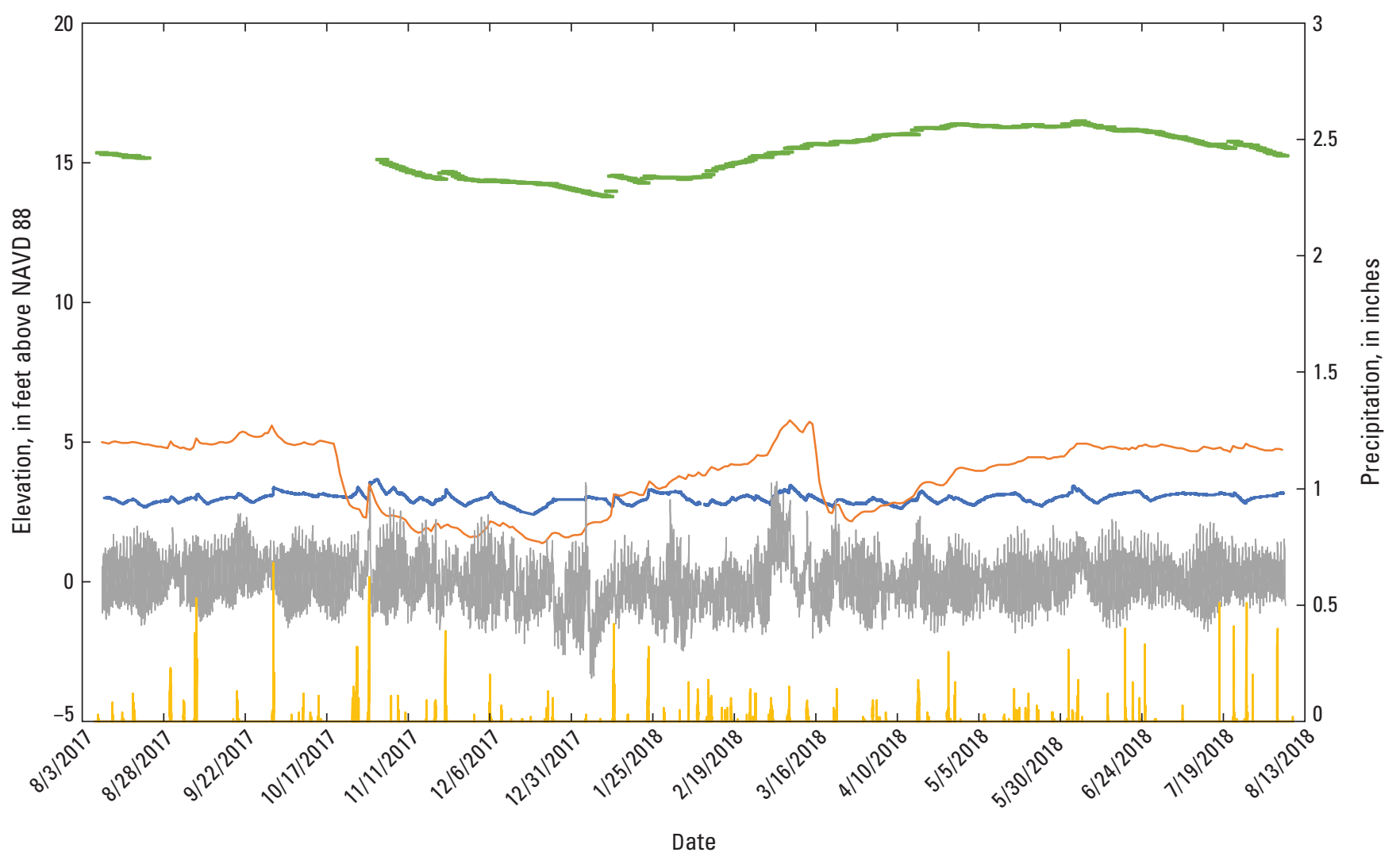

EXPLANATION
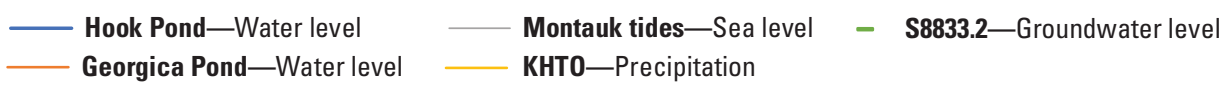

Figure 7. Continuous water-surface elevation data from Hook Pond site 10 (Maidstone Club golf cart bridge) in East Hampton, New York, continuous water-surface elevation data from nearby Georgica Pond, continuous tide elevation data from the National Oceanic and Atmospheric Administration (NOAA) Montauk tide gage, continuous groundwater elevation data from U.S. Geological Survey observation well S8833.2 - all in feet above the North American Vertical Datum of 1988 (NAVD 88), converted from the National Geodetic Vertical Datum of 1929 (NOAA, 2019) where applicable; daily precipitation data are from East Hampton Airport (KHTO).

consistently lower than at sites measured throughout Hook Pond, reflecting contributions of less oxygenated groundwater, particularly at Fithian Lane (fig. 8; appendix tables 2.2 and 2.3).

Turbidity values throughout Hook Pond were relatively consistent, ranging from 0.40 to 29 formazin nephelometric units (appendix tables 2.2 and 2.3; fig. 8), and can be affected in the pond by wind and turbulence caused by fish. Turbidity along Hook Pond Dreen ranged from less than 1.0 to 21 formazin nephelometric units, with mostly upstream waterfowl and stormwater from the outfall at Fithian Lane causing higher values.

Total algae fluorescence throughout Hook Pond varied, and values were consistently lower at Hook Pond sites 1, 6, 8, and 10 than at sites 2, 3, 4, 5, and 7 (fig. 8; appendix tables 2.2 and 2.3). Chlorophyll $a$ concentrations (as determined by fluorescence) ranged from less than 1.0 to $53 \mu \mathrm{g} / \mathrm{L}$ throughout Hook Pond and were highest in the summer months, though summer concentrations were low relative to concentrations observed during algal blooms (Graham and others, 2004). This finding is consistent with field observations of little to no green algae in the main pond during the duration of the study. Chlorophyll $a$ also exhibited the greatest variability throughout the pond on a given day. Similarly, phycocyanin concentrations were highest in the summer months; most values were measured at less than $1.0 \mu \mathrm{g} / \mathrm{L}$, and the maximum concentration (as determined by fluorescence) was $2.53 \mu \mathrm{g} / \mathrm{L}$. Chlorophyll $a$ and phycocyanin concentrations along Hook Pond Dreen were lower than those of Hook Pond.

Secchi depth values ranged from 0.41 to $2.9 \mathrm{ft}$ throughout the sites in Hook Pond. These values represent the extent to which light penetrates the water column and, along with turbidity, can be used to characterize clarity and are useful in understanding depths at which photosynthetic algae are active during the day. Water clarity and turbidity reflect suspended sediment and organic matter concentrations, algae biomass, 


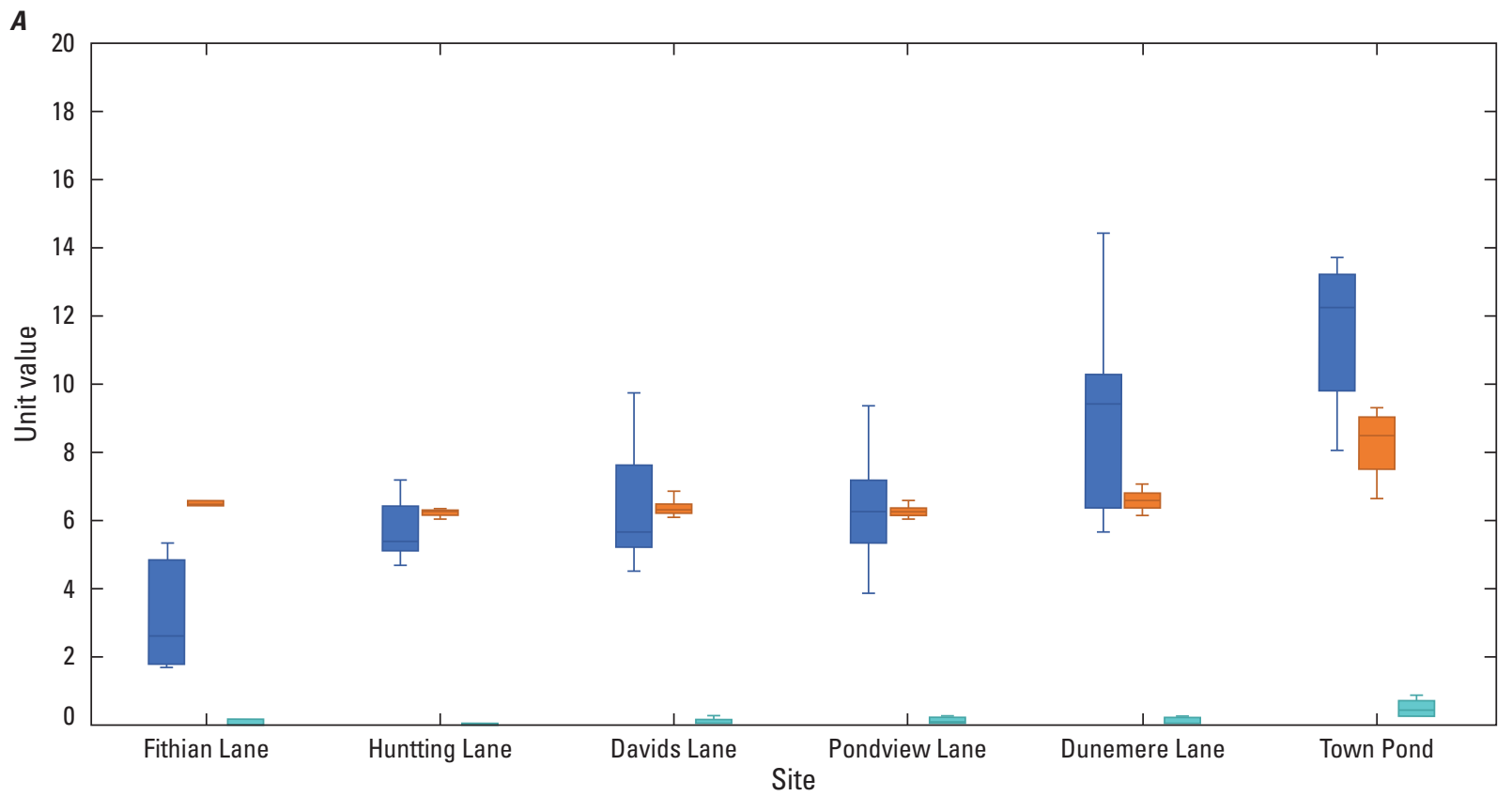

B

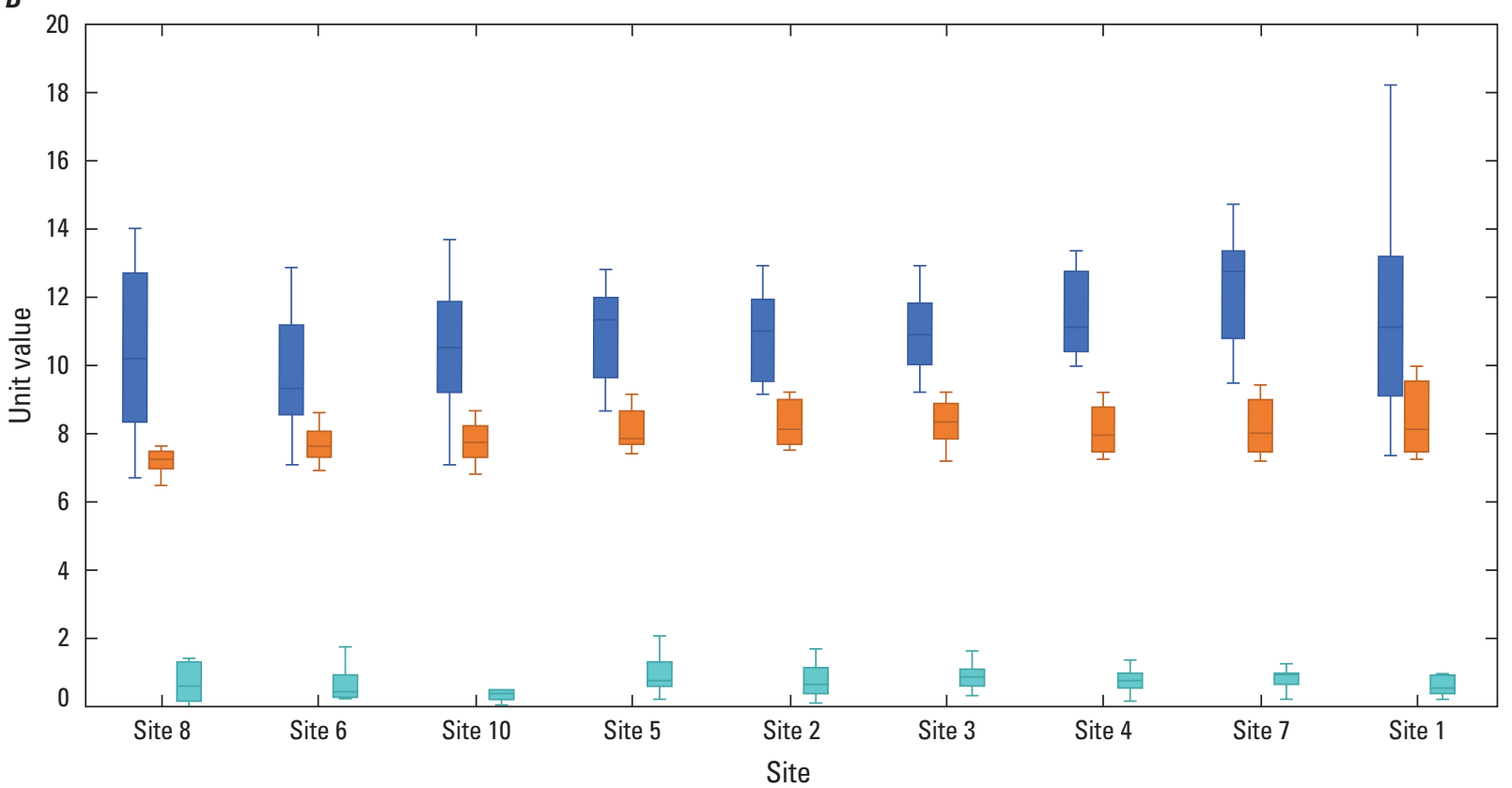

EXPLANATION

\begin{tabular}{|c|c|}
\hline Dissolved oxygen (mg/L) & $\begin{array}{l}\text { 90th percentile } \\
\text { 75th percentile }\end{array}$ \\
\hline & 50th percentile-Median \\
\hline Phycocyanin ( $\mu \mathrm{g} / \mathrm{L}$ ) & $\begin{array}{l}\text { 25th percentile } \\
\text { 10th percentile }\end{array}$ \\
\hline
\end{tabular}

Figure 8. Physical constituents from August 2017 through August 2018 at sites along Hook Pond Dreen, within Hook Pond, and at the eastern shoreline of Town Pond in East Hampton, New York. Sites are listed in approximate downstream order beginning with Hook Pond Dreen at Fithian Lane through Hook Pond site 7. For each sampling event, measurements from a single value representing the middle of the water column per day per site were used: $A$ and $B$, dissolved oxygen, $\mathrm{pH}$, and phycocyanin (determined by fluorescence), and $C$ and $D$, turbidity and chlorophyll a (determined by fluorescence). Sample size (that is, number of data points per boxplot) ranged from 3 to 24 for Hook Pond Dreen and Town Pond sites and from 7 to 19 for Hook Pond depth profiles, depending on site and constituent. Significant differences $(P<0.05)$ between average values of chlorophyll $a$ are represented by letters a and $b$. FNU, formazin nephelometric unit; $\mathrm{mg} / \mathrm{L}$, milligram per liter; $\mu \mathrm{g} / \mathrm{L}$, microgram per liter. 

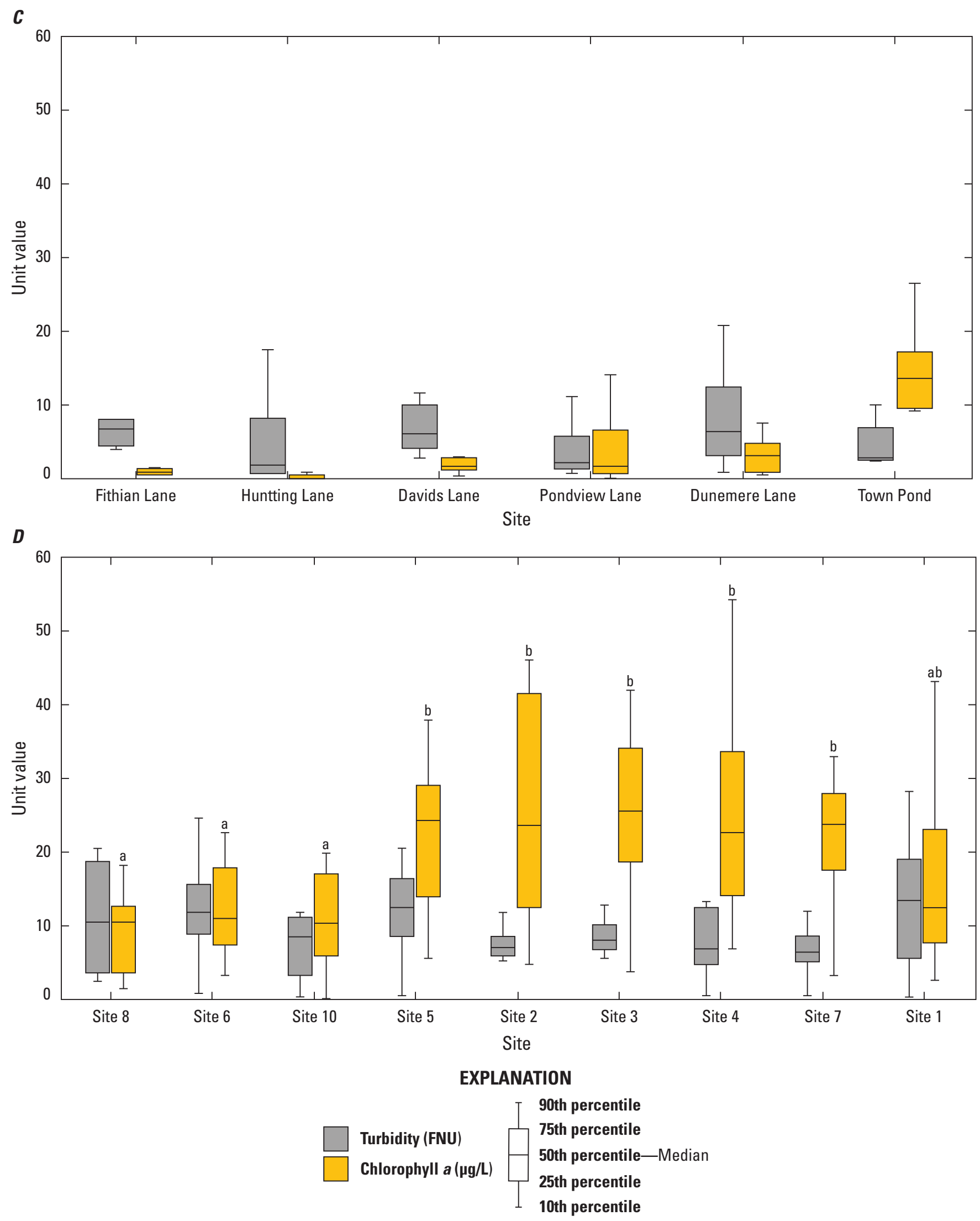

Figure 8. - Continued 
and bioturbation and wind-driven upwelling, which can all vary greatly throughout the day depending on weather, season, and nutrient availability. However, there was little correlation between turbidity or chlorophyll $a$ and Secchi depth throughout the pond (linear regression $R^{2}$ of 0.19 and 0.08 , respectively, was found to be greater than or equal to [respectively] the expected exponential $R^{2}$ in both cases; appendix fig. 2.2) or on a site-by-site basis. Therefore, water clarity appears to be more related to dissolved organic matter, which was observed (but not analyzed for) in some samples analyzed for nutrients, in which filtered pond water remained tinted light brown.

\section{Spatiotemporal Assessment of Nutrients and Wastewater-Indicator Compounds in the Hook Pond Watershed}

Ammonia concentrations in Hook Pond were generally low over the course of the study; values were consistently low in spring and summer months $(<0.06 \mathrm{mg} / \mathrm{L}$ as nitrogen $)$ and only slightly elevated (with a range of $0.03-0.55 \mathrm{mg} / \mathrm{L}$ as nitrogen) in the late autumn (November-December 2017) and winter months (January-March 2018; figs. 9 and 10; tables 3 and 4). The seasonal variability observed in samples analyzed for ammonia plus organic nitrogen was the result of the variability of ammonia. Concentrations of organic nitrogen (determined by subtracting ammonium from ammonia plus organic nitrogen) throughout the year ranged from 0.21 to $0.46 \mathrm{mg} / \mathrm{L}$ as nitrogen in the filtered samples and from 0.48 to $1.29 \mathrm{mg} / \mathrm{L}$ as nitrogen in the unfiltered samples. By contrast, concentrations of organic nitrogen in Hook Pond Dreen were relatively low during winter snowmelt and during nonstorm conditions (ranging from 0.12 to $0.34 \mathrm{mg} / \mathrm{L}$ as nitrogen) and elevated during storm conditions (from 0.22 to $1.45 \mathrm{mg} / \mathrm{L}$ as nitrogen) in filtered organic nitrogen (fig. 10A; tables 3 and 4). Samples collected during two storm events did not indicate elevated ammonia in the pond, whereas ammonia concentrations along Hook Pond Dreen were elevated during storm and snowmelt events (fig. 11; tables 3 and 4), with concentrations at Fithian Lane typically highest for a given event and under normal (nonstorm) conditions.

Nitrate plus nitrite concentrations in Hook Pond varied seasonally to a greater degree than those of ammonia (figs. 9 and 10), and nitrite concentrations were small relative to the sum of nitrate plus nitrite (tables 3 and 4). Concentrations of nitrate observed in the winter months were significantly higher than those observed in the summer and autumn $(P<0.050)$, whereas median concentrations of samples from autumn and winter did not differ significantly from spring samples (fig. 10). The range of nitrate plus nitrite concentrations observed in Hook Pond was greater than those of the other nitrogen species $(<0.040-2.64 \mathrm{mg} / \mathrm{L}$ as nitrogen), with concentrations of nitrite not greater than $0.06 \mathrm{mg} / \mathrm{L}$ as nitrogen. Similar ranges of nitrate were observed along Hook Pond Dreen despite the seasonal differences, which is indicative of a sustained nitrate source, such as groundwater. Concentrations of nitrate plus nitrite were relatively high $(1.44 \mathrm{mg} / \mathrm{L}$ as nitrogen) at Fithian Lane under nonstorm conditions, representing a groundwater source, which becomes diluted during storm conditions and downstream at other sites during the same sampling event (fig. 11; tables 3 and 4).

Similar to calculated values of organic nitrogen, total nitrogen values can be calculated by adding the nitrate plus nitrite and the ammonia plus organic nitrogen (tables 3 and 4). In the summer months, total nitrogen concentrations, both filtered and unfiltered, were predominately organic nitrogen, ammonia, or both, in Hook Pond (fig. 10). In early autumn through early spring, the relative proportion of nitrate increased and accounted for more than half of the total nitrogen of the sample. Concentrations of total nitrogen in the summer ranged from 0.48 to $1.04 \mathrm{mg} / \mathrm{L}$ as nitrogen (filtered) and from 1.01 to $1.77 \mathrm{mg} / \mathrm{L}$ as nitrogen (unfiltered), whereas, during the rest of the year, concentrations ranged from 0.94 to $2.90 \mathrm{mg} / \mathrm{L}$ as nitrogen (filtered) and from 1.31 to $3.62 \mathrm{mg} / \mathrm{L}$ as nitrogen (unfiltered; tables 3 and 4). Total nitrogen concentrations in Hook Pond Dreen were similar to those of organic nitrogen at seasonal and event scales (fig. 11).

Isotopes of nitrogen and oxygen in nitrate can be used to differentiate sources and transformation of nitrate and ammonium and groundwater. Natural denitrification and microbial processes result in different isotope signatures than those of nitrogen-based fertilizers and septic influence. Nitrogen and oxygen isotope data from Hook Pond and tributaries as well as groundwater suggest similar, mostly septic influence (fig. 12; tables 3 and 4; Abbene, 2010). Shifts in $\delta^{15 N}$ and $\delta^{18} \mathrm{O}$ ratios in stormwater reflect mixing (dilution) of stormwater runoff with groundwater seepage. The shift in $\delta^{15} \mathrm{~N}$ and $\delta^{18} \mathrm{O}$ downstream likely reflects a combination of dentification and mixing, with the source originating from a combination natural and septic influence (Burns and others, 2009).

Total phosphorus concentrations in Hook Pond ranged from 0.004 to $0.010 \mathrm{mg} / \mathrm{L}$ as phosphorus in filtered samples and from 0.060 to $0.095 \mathrm{mg} / \mathrm{L}$ as phosphorus in unfiltered samples (fig. 10; tables 3 and 4). Unlike nitrogen, concentrations of total phosphorus did not vary significantly by season ( $P=0.919$; fig. 10). Most (75-92 percent) of the total phosphorus detected in samples was in the particulate fraction (that is, larger than $0.45 \mu \mathrm{m}$ ). In contrast, the percentage of the total phosphorus in Hook Pond Dreen samples in the filtered fraction was larger (15-71 percent), and a majority entered or passed at Fithian Lane. A large fraction of the total phosphorus in Hook Pond Dreen was composed of orthophosphate (58-107 percent), suggesting that the phosphorus was in a readily available state for biological use by algae. In contrast, concentrations of orthophosphate in all Hook Pond samples were less than the detection limit of $0.004 \mathrm{mg} / \mathrm{L}$ as phosphorus (tables 3 and 4). Although concentrations of unfiltered total phosphorus in Hook Pond Dreen snowmelt and storm events were similar to those under nonstorm conditions and what was quantified for Hook Pond $(P=0.119)$, concentrations of filtered phosphorus were significantly different along Hook Pond Dreen from those in Hook Pond $(P<0.050)$. 


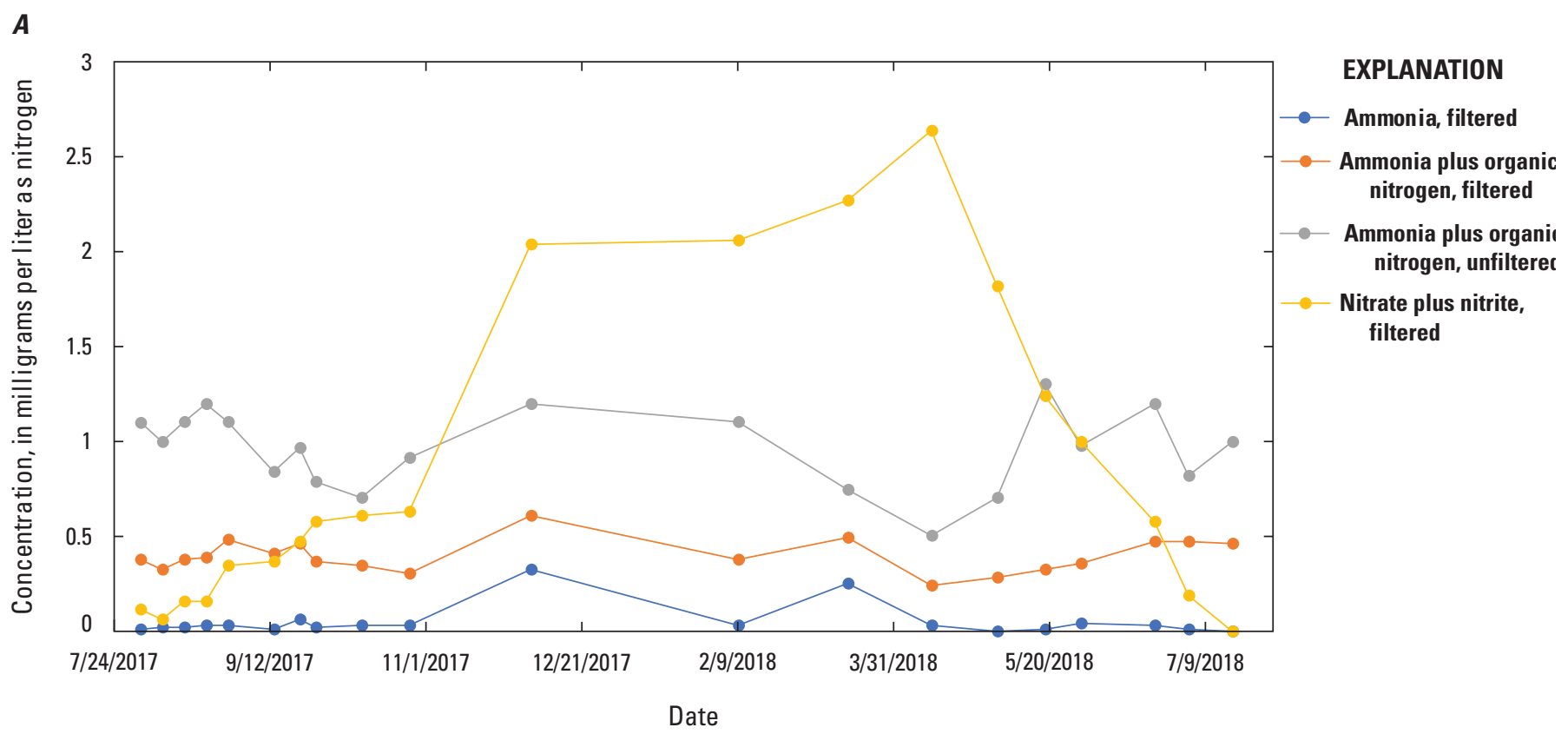

B

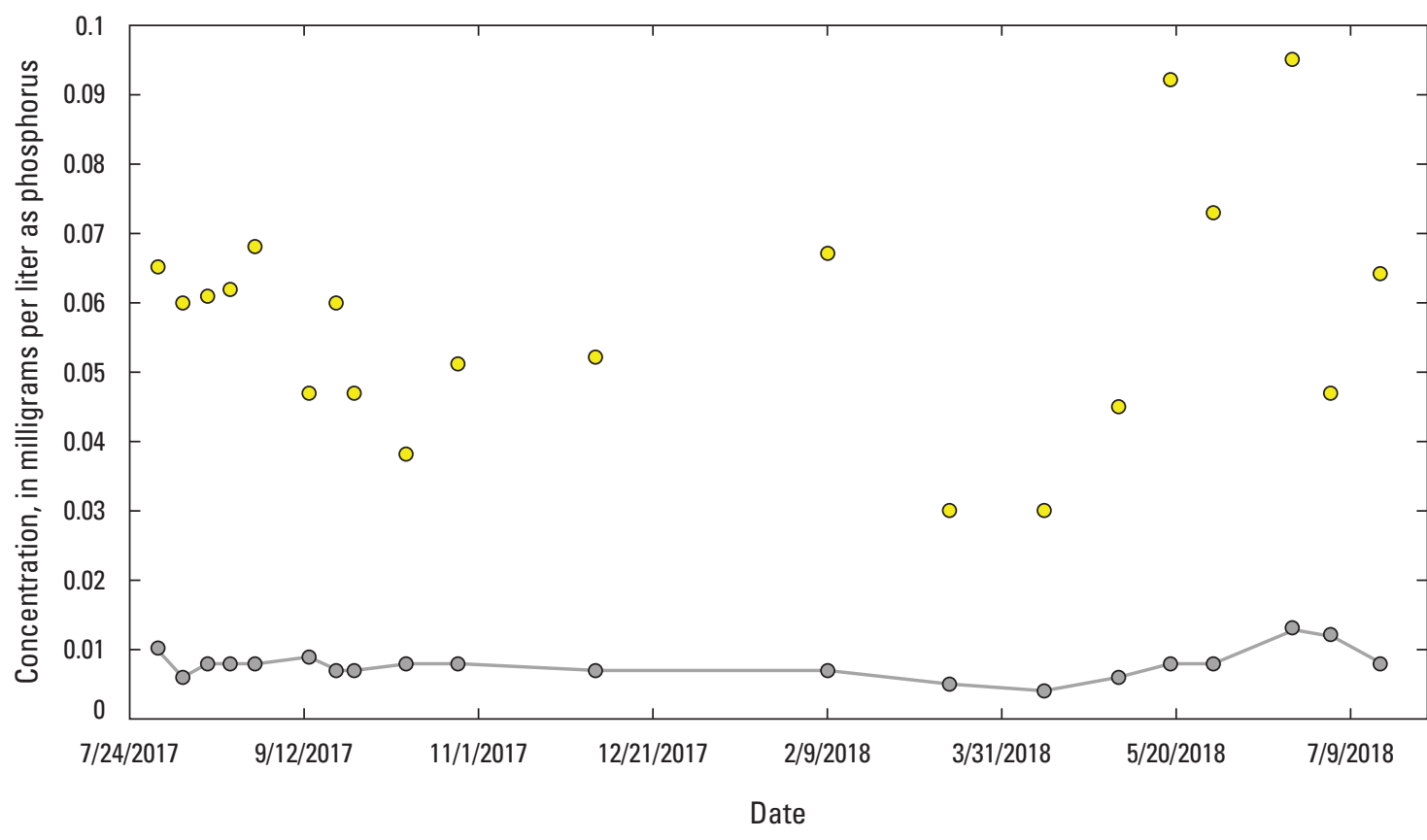

EXPLANATION

- - Total phosphorus, filtered

○ Total phosphorus, unfiltered

Figure 9. Concentrations of $A$, various forms of nitrogen and $B$, total phosphorus collected at Hook Pond site 3 in East Hampton, New York, between August 1, 2017, and July 16, 2018. Lines are for illustrative purposes only and do not imply that values fall along the lines between points. 
$\boldsymbol{A}$

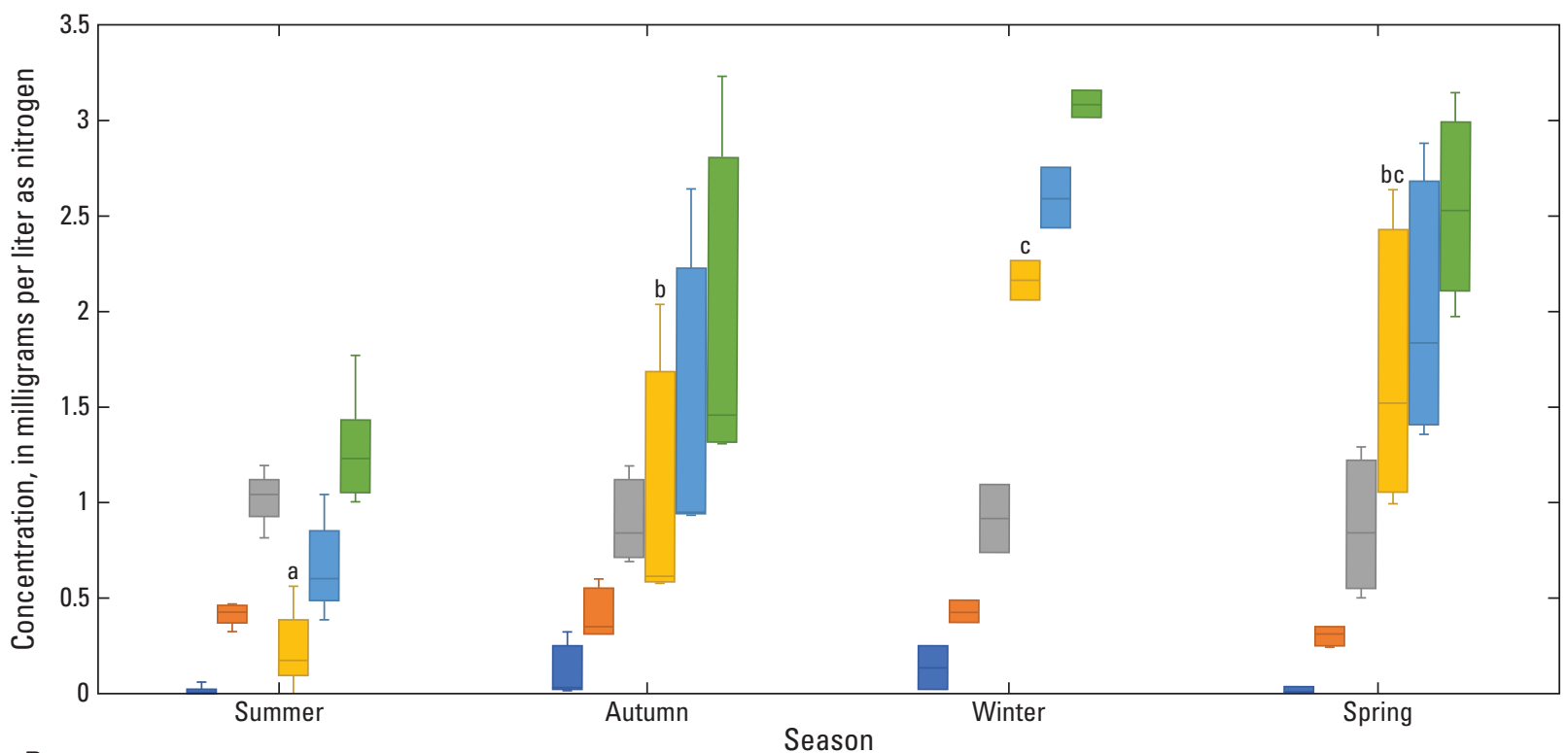

$B$

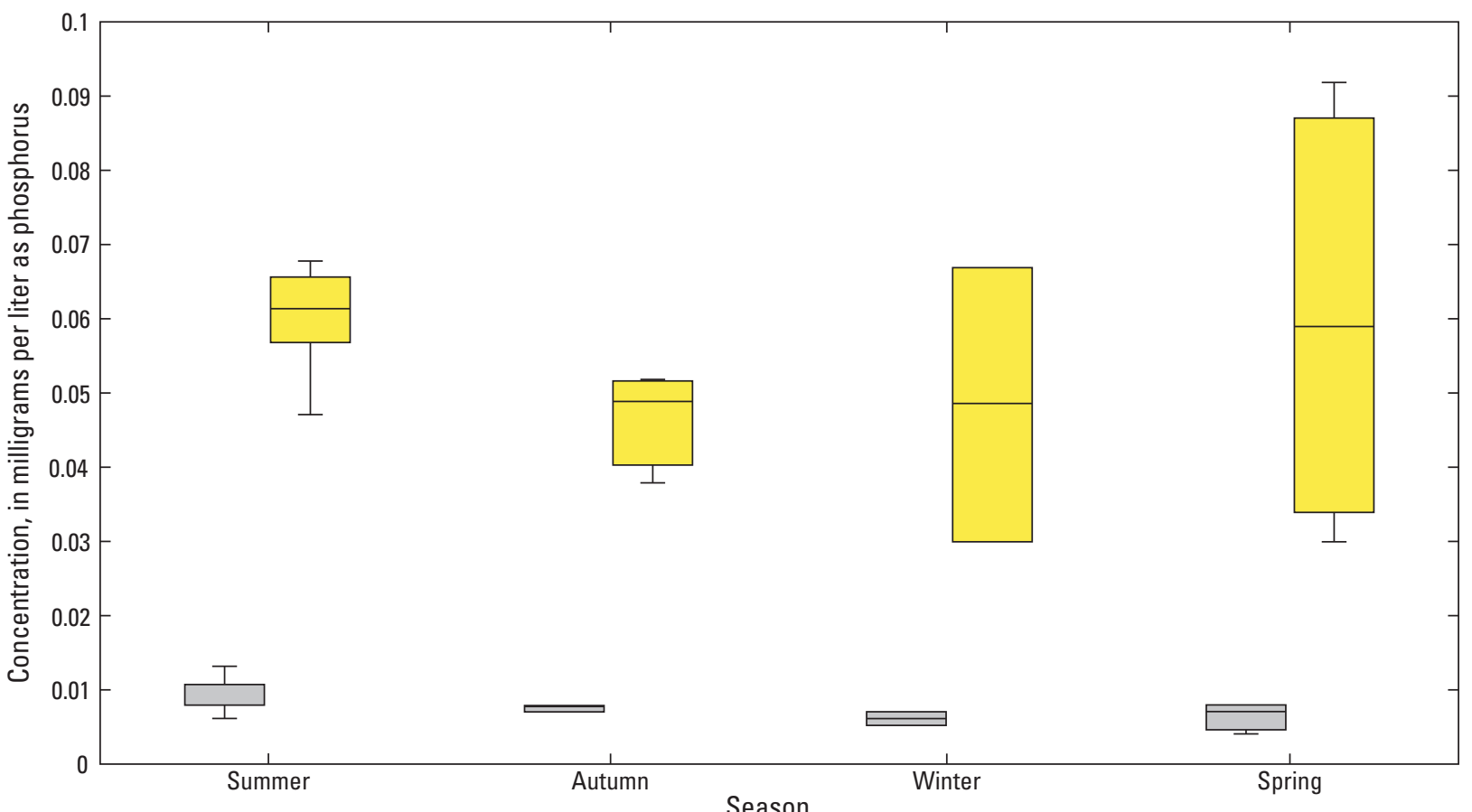

\section{EXPLANATION}

Ammonia-Filtered

Ammonia plus organic nitrogen-Filtered

Ammonia plus organic nitrogen-Unfiltered

Nitrate plus nitrite-Filtered
Total nitrogen-Filtered (calculated)

Total nitrogen-Unfiltered (calculated)

Total phosphorus-Filtered

Total phosphorus-Unfiltered

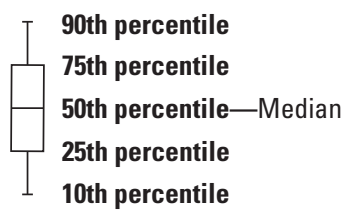

Figure 10. Seasonal representation of $A$, nitrogen and $B$, phosphorus concentrations in Hook Pond (combined data from Hook Pond sites 3, 7, and 10), East Hampton, New York. Sample size for summer is 10 , for autumn is 5 , for winter is 3 , and for spring is 4 . Total nitrogen is equal to the sum of nitrate plus nitrite and ammonia plus organic nitrogen and is calculated for both filtered and unfiltered nitrogen. Significant differences $(P<0.05)$ between average values of nitrate plus nitrite, which in turn create significant differences in total nitrogen, are indicated by letters a, b, and c. Seasons: June 21-September 22, summer; September 23-December 20, autumn; December 21-March 19, winter; and March 20-June 20, spring. 
[Concentrations of nutrients in surface water and groundwater determined by U.S. Geological Survey National Water Quality Laboratory schedules 2702 and 2755 , respectively. Sample event denotes conditions under which a sample was collected and whether it is considered a storm or nonstorm (normal) sample. Analytical methods that determine concentrations of ammonia represent both ammonia ( $\mathrm{NH}_{3}$ ) and ammonium $\left(\mathrm{NH}_{4}^{+}\right) ; \mathrm{mg} / \mathrm{L}-\mathrm{N}$, milligram per liter as nitrogen; per mil, parts per thousand; —, not analyzed; <, less than; NA, not applicable.]

\begin{tabular}{|c|c|c|c|c|c|c|c|c|c|c|c|c|c|c|}
\hline Site name & Sample date & $\begin{array}{c}\text { Sample } \\
\text { time }\end{array}$ & $\begin{array}{c}\text { Sample } \\
\text { event }\end{array}$ & $\begin{array}{c}\text { Ammonia } \\
\left(\mathrm{NH}_{3}+\right. \\
\left.\mathrm{NH}_{4}\right)^{+}, \\
\text {filtered } \\
\text { (mg/L-N) }\end{array}$ & $\begin{array}{c}\text { Ammonia } \\
\text { plus } \\
\text { organic } \\
\text { nitrogen, } \\
\text { filtered } \\
\text { (mg/L-N) }\end{array}$ & $\begin{array}{c}\text { Ammonia } \\
\text { plus } \\
\text { organic } \\
\text { nitrogen, } \\
\text { unfiltered } \\
\text { (mg/L-N) }\end{array}$ & $\begin{array}{c}\text { Nitrate } \\
\text { plus } \\
\text { nitrite, } \\
\text { filtered } \\
\text { (mg/L-N) }\end{array}$ & $\begin{array}{l}\text { Nitrite, } \\
\text { filtered } \\
\text { (mg/L-N) }\end{array}$ & $\begin{array}{c}\text { Total nitro- } \\
\text { gen [nitrate } \\
+ \text { nitrite + } \\
\text { ammonia + } \\
\text { organic-N], } \\
\text { filtered, } \\
\text { analytically } \\
\text { determined } \\
\text { (mg/L-N) }\end{array}$ & $\begin{array}{c}\text { Total } \\
\text { nitrogen } \\
\text { [nitrate + } \\
\text { nitrite + } \\
\text { ammonia } \\
\text { + organic- } \\
\text { N], } \\
\text { filtered, } \\
\text { calcu- } \\
\text { lated } \\
\text { (mg/L-N) }\end{array}$ & $\begin{array}{c}\text { Total } \\
\text { nitrogen } \\
\text { [nitrate + } \\
\text { nitrite + } \\
\text { ammonia } \\
\text { + organic- } \\
\text { N], } \\
\text { unfiltered, } \\
\text { calculated } \\
\text { (mg/L-N) }\end{array}$ & $\begin{array}{c}\text { Delta } \\
\text { nitrogen-15/ } \\
\text { nitrogen-14 } \\
\text { of ammonia, } \\
\text { filtered (per } \\
\text { mil) }\end{array}$ & $\begin{array}{c}\text { Delta } \\
\text { nitrogen-15/ } \\
\text { nitrogen-14 } \\
\text { of nitrate, } \\
\text { filtered (per } \\
\text { mil) }\end{array}$ & $\begin{array}{c}\text { Delta } \\
\text { oxygen-18/ } \\
\text { oxygen-16 } \\
\text { of nitrate, } \\
\text { water, } \\
\text { filtered } \\
\text { (per mil) }\end{array}$ \\
\hline \multicolumn{15}{|c|}{ Surface water } \\
\hline \multirow[t]{3}{*}{$\begin{array}{l}\text { Hook Pond } \\
\text { (site 10) }\end{array}$} & $11 / 21 / 2017$ & 1130 & Normal & 0.55 & 0.88 & 1.6 & 2.02 & 0.058 & - & 2.90 & 3.62 & - & - & - \\
\hline & $3 / 15 / 2018$ & 1020 & Normal & 0.30 & 0.56 & 1.2 & 2.33 & 0.021 & - & 2.89 & 3.53 & - & - & - \\
\hline & $7 / 23 / 2018$ & 1015 & Normal & $<0.01$ & 0.41 & 0.84 & 0.218 & 0.017 & - & 0.63 & 1.06 & - & - & - \\
\hline \multirow[t]{19}{*}{$\begin{array}{l}\text { Hook Pond } \\
\quad \text { (site } 3 \text { ) }\end{array}$} & $8 / 1 / 2017$ & 1150 & Normal & 0.01 & 0.38 & 1.1 & 0.12 & 0.009 & - & 0.50 & 1.22 & - & - & - \\
\hline & 8/8/2017 & 1030 & Normal & 0.02 & 0.33 & 1.0 & 0.065 & 0.005 & - & 0.40 & 1.07 & - & - & - \\
\hline & $8 / 15 / 2017$ & 1040 & Normal & 0.02 & 0.38 & 1.1 & 0.16 & 0.007 & - & 0.54 & 1.26 & - & - & - \\
\hline & $8 / 22 / 2017$ & 1058 & Normal & 0.03 & 0.39 & 1.2 & 0.164 & 0.010 & - & 0.55 & 1.36 & - & - & - \\
\hline & $8 / 29 / 2017$ & 1028 & Normal & 0.03 & 0.48 & 1.1 & 0.345 & 0.013 & - & 0.83 & 1.45 & - & - & - \\
\hline & $9 / 13 / 2017$ & 1215 & Normal & 0.01 & 0.41 & 0.84 & 0.365 & 0.018 & - & 0.78 & 1.21 & - & - & - \\
\hline & $9 / 21 / 2017$ & 1024 & Normal & 0.06 & 0.46 & 0.97 & 0.47 & 0.018 & - & 0.93 & 1.44 & - & - & - \\
\hline & $9 / 26 / 2017$ & 1040 & Normal & 0.02 & 0.37 & 0.79 & 0.584 & 0.022 & - & 0.95 & 1.37 & - & - & - \\
\hline & $10 / 11 / 2017$ & 1110 & Normal & 0.03 & 0.35 & 0.7 & 0.609 & 0.021 & - & 0.96 & 1.31 & - & - & - \\
\hline & $10 / 26 / 2017$ & 1055 & Normal & 0.03 & 0.31 & 0.91 & 0.629 & 0.019 & - & 0.94 & 1.54 & - & - & - \\
\hline & $12 / 4 / 2017$ & 1305 & Normal & 0.33 & 0.61 & 1.2 & 2.04 & 0.041 & - & 2.65 & 3.24 & - & - & - \\
\hline & $2 / 8 / 2018$ & 1215 & Normal & 0.03 & 0.38 & 1.1 & 2.06 & 0.019 & - & 2.44 & 3.16 & - & - & - \\
\hline & $4 / 11 / 2018$ & 1130 & Normal & 0.03 & 0.24 & 0.51 & 2.64 & 0.028 & - & 2.88 & 3.15 & - & - & - \\
\hline & $5 / 2 / 2018$ & 1230 & Normal & $<0.01$ & 0.29 & 0.7 & 1.82 & 0.031 & - & 2.11 & 2.52 & - & - & - \\
\hline & $15 / 2 / 2018$ & 1231 & Normal & $<0.01$ & 0.25 & 0.63 & 1.87 & 0.031 & - & 2.12 & 2.50 & - & - & - \\
\hline & $5 / 17 / 2018$ & 1245 & Storm & 0.01 & 0.33 & 1.3 & 1.24 & 0.034 & - & 1.57 & 2.54 & - & - & - \\
\hline & $5 / 29 / 2018$ & 1200 & Normal & 0.04 & 0.36 & 0.98 & 1.00 & 0.039 & - & 1.36 & 1.98 & - & - & - \\
\hline & $6 / 21 / 2018$ & 1130 & Storm & 0.03 & 0.47 & 1.2 & 0.574 & 0.027 & - & 1.04 & 1.77 & - & 9.70 & 5.31 \\
\hline & $7 / 2 / 2018$ & 1056 & Normal & 0.01 & 0.47 & 0.82 & 0.186 & 0.015 & - & 0.66 & 1.01 & - & - & - \\
\hline
\end{tabular}


Table 3. Concentrations and isotope fractions of nitrogen species collected in the Hook Pond watershed, East Hampton, New York.-Continued

[Concentrations of nutrients in surface water and groundwater determined by U.S. Geological Survey National Water Quality Laboratory schedules 2702 and 2755 , respectively. Sample event denotes conditions under which a sample was collected and whether it is considered a storm or nonstorm (normal) sample. Analytical methods that determine concentrations of ammonia represent both ammonia ( $\mathrm{NH}_{3}$ ) and ammonium $\left(\mathrm{NH}_{4}^{+}\right) ; \mathrm{mg} / \mathrm{L}-\mathrm{N}$, milligram per liter as nitrogen; per mil, parts per thousand; -, not analyzed; <, less than; NA, not applicable.]

\begin{tabular}{|c|c|c|c|c|c|c|c|c|c|c|c|c|c|c|}
\hline Site name & Sample date & $\begin{array}{c}\text { Sample } \\
\text { time }\end{array}$ & $\begin{array}{c}\text { Sample } \\
\text { event }\end{array}$ & $\begin{array}{c}\text { Ammonia } \\
\left(\mathrm{NH}_{3}+\right. \\
\left.\mathrm{NH}_{4}+\right) \\
\text { filtered } \\
\text { (mg/L-N) }\end{array}$ & $\begin{array}{l}\text { Ammonia } \\
\text { plus } \\
\text { organic } \\
\text { nitrogen, } \\
\text { filtered } \\
\text { (mg/L-N) }\end{array}$ & $\begin{array}{l}\text { Ammonia } \\
\text { plus } \\
\text { organic } \\
\text { nitrogen, } \\
\text { unfiltered } \\
\text { (mg/L-N) }\end{array}$ & $\begin{array}{c}\text { Nitrate } \\
\text { plus } \\
\text { nitrite, } \\
\text { filtered } \\
\text { (mg/L-N) }\end{array}$ & $\begin{array}{l}\text { Nitrite, } \\
\text { filtered } \\
\text { (mg/L-N) }\end{array}$ & $\begin{array}{c}\text { Total nitro- } \\
\text { gen [nitrate } \\
+ \text { nitrite + } \\
\text { ammonia + } \\
\text { organic-N], } \\
\text { filtered, } \\
\text { analytically } \\
\text { determined } \\
\text { (mg/L-N) }\end{array}$ & $\begin{array}{c}\text { Total } \\
\text { nitrogen } \\
\text { [nitrate + } \\
\text { nitrite + } \\
\text { ammonia } \\
\text { + organic- } \\
\text { N], } \\
\text { filtered, } \\
\text { calcu- } \\
\text { lated } \\
\text { (mg/L-N) }\end{array}$ & $\begin{array}{c}\text { Total } \\
\text { nitrogen } \\
\text { [nitrate + } \\
\text { nitrite + } \\
\text { ammonia } \\
\text { + organic- } \\
\text { N], } \\
\text { unfiltered, } \\
\text { calculated } \\
\text { (mg/L-N) }\end{array}$ & $\begin{array}{c}\text { Delta } \\
\text { nitrogen-15/ } \\
\text { nitrogen-14 } \\
\text { of ammonia, } \\
\text { filtered (per } \\
\quad \text { mil) }\end{array}$ & $\begin{array}{c}\text { Delta } \\
\text { nitrogen-15/ } \\
\text { nitrogen-14 } \\
\text { of nitrate, } \\
\text { filtered (per } \\
\text { mil) }\end{array}$ & $\begin{array}{c}\text { Delta } \\
\text { oxygen-18/ } \\
\text { oxygen-16 } \\
\text { of nitrate, } \\
\text { water, } \\
\text { filtered } \\
\text { (per mil) }\end{array}$ \\
\hline \multicolumn{15}{|c|}{ Surface water-Continued } \\
\hline & $7 / 16 / 2018$ & 1155 & Normal & $<0.01$ & 0.46 & 1.0 & 0.02 & 0.001 & - & 0.48 & 1.02 & - & - & - \\
\hline & $7 / 23 / 2018$ & 1120 & Normal & $<0.01$ & 0.47 & 0.97 & 0.02 & 0.004 & - & 0.49 & 0.99 & - & - & - \\
\hline & $7 / 30 / 2018$ & 1230 & Normal & 0.01 & 0.44 & 1.2 & 0.02 & 0.002 & - & 0.46 & 1.22 & - & - & - \\
\hline $\begin{array}{l}\text { Hook Pond } \\
\text { (site 4) }\end{array}$ & $6 / 21 / 2018$ & 1200 & Storm & 0.01 & 0.51 & 1.3 & 0.551 & 0.024 & - & 1.06 & 1.85 & - & 9.66 & 5.46 \\
\hline $\begin{array}{l}\text { Hook Pond } \\
\text { (site 7) }\end{array}$ & $3 / 15 / 2018$ & 1145 & Normal & 0.25 & 0.49 & 0.75 & 2.27 & 0.028 & - & 2.76 & 3.02 & - & - & - \\
\hline \multirow[t]{4}{*}{ Fithian Lane } & $1 / 10 / 2018$ & 1015 & $\begin{array}{l}\text { Snow- } \\
\text { melt }\end{array}$ & 0.88 & 1.2 & 1.5 & 0.654 & 0.053 & - & 1.85 & 2.15 & - & 12.89 & 5.71 \\
\hline & $6 / 21 / 2018$ & 1100 & Storm & 0.34 & 0.84 & 1.1 & 0.879 & 0.028 & - & 1.72 & 1.98 & - & 8.89 & 9.53 \\
\hline & $7 / 6 / 2018$ & 1150 & Storm & 1.25 & 2.7 & 3.2 & 0.764 & 0.038 & - & 3.46 & 3.96 & - & 6.54 & 10.14 \\
\hline & $8 / 7 / 2018$ & 1045 & Normal & 0.76 & 1.1 & 1.2 & 1.44 & 0.075 & - & 2.54 & 2.64 & - & 12.57 & 3.90 \\
\hline \multirow[t]{2}{*}{ Huntting Lane } & $1 / 10 / 2018$ & 1050 & $\begin{array}{l}\text { Snow- } \\
\text { melt }\end{array}$ & 0.65 & 0.77 & 0.9 & 3.41 & 0.015 & - & 4.18 & 4.31 & - & 8.75 & 2.27 \\
\hline & $6 / 21 / 2018$ & 1030 & Storm & 0.36 & 0.72 & 0.81 & 2.53 & 0.022 & - & 3.25 & 3.34 & - & 9.31 & 2.92 \\
\hline $\begin{array}{l}\text { Davids Lane } \\
\text { (north) }\end{array}$ & $6 / 21 / 2018$ & 1000 & Storm & 0.33 & 0.73 & 0.95 & 2.18 & 0.023 & & 2.91 & 3.13 & - & 9.40 & 3.39 \\
\hline \multirow[t]{3}{*}{$\begin{array}{l}\text { Davids Lane } \\
\text { (south) }\end{array}$} & $1 / 10 / 2018$ & 1120 & $\begin{array}{l}\text { Snow- } \\
\text { melt }\end{array}$ & 0.62 & 0.89 & 1.3 & 3.17 & 0.023 & - & 4.06 & 4.47 & - & 9.27 & 2.80 \\
\hline & $6 / 21 / 2018$ & 0930 & Storm & 0.33 & 0.85 & 1.1 & 1.76 & 0.03 & - & 2.61 & 2.86 & - & 9.59 & 4.50 \\
\hline & $8 / 7 / 2018$ & 1050 & Normal & 0.42 & 0.65 & 1.2 & 2.96 & 0.046 & - & 3.61 & 4.16 & - & 10.34 & 2.96 \\
\hline \multirow[t]{4}{*}{$\begin{array}{l}\text { Dunemere } \\
\text { Lane }\end{array}$} & $1 / 10 / 2018$ & 1210 & $\begin{array}{l}\text { Snow- } \\
\text { melt }\end{array}$ & 0.47 & 0.81 & 1.1 & 2.75 & 0.027 & - & 3.56 & 3.85 & - & 9.29 & 2.90 \\
\hline & $6 / 21 / 2018$ & 0830 & Storm & 0.39 & 0.61 & 0.81 & 2.52 & 0.043 & - & 3.13 & 3.33 & - & 9.72 & 3.40 \\
\hline & $7 / 6 / 2018$ & 1300 & Storm & 0.12 & 0.34 & 0.76 & 2.40 & 0.048 & - & 2.74 & 3.16 & - & 10.16 & 3.27 \\
\hline & $8 / 7 / 2018$ & 0910 & Normal & 0.33 & 0.52 & 1.1 & 2.02 & 0.058 & - & 2.54 & 3.12 & - & 10.66 & 3.76 \\
\hline
\end{tabular}


[Concentrations of nutrients in surface water and groundwater determined by U.S. Geological Survey National Water Quality Laboratory schedules 2702 and 2755 , respectively. Sample event denotes conditions under which a sample was collected and whether it is considered a storm or nonstorm (normal) sample. Analytical methods that determine concentrations of ammonia represent both ammonia $\left(\mathrm{NH}_{3}\right)$ and ammonium $\left(\mathrm{NH}_{4}^{+}\right) ; \mathrm{mg} / \mathrm{L}-\mathrm{N}$, milligram per liter as nitrogen; per mil, parts per thousand; —, not analyzed; <, less than; NA, not applicable.]

\begin{tabular}{|c|c|c|c|c|c|c|c|c|c|c|c|c|c|c|}
\hline Site name & Sample date & $\begin{array}{l}\text { Sample } \\
\text { time }\end{array}$ & $\begin{array}{c}\text { Sample } \\
\text { event }\end{array}$ & $\begin{array}{c}\text { Ammonia } \\
\left(\mathrm{NH}_{3}+\right. \\
\left.\mathrm{NH}_{4}+\right) \\
\text { filtered } \\
\text { (mg/L-N) }\end{array}$ & $\begin{array}{l}\text { Ammonia } \\
\text { plus } \\
\text { organic } \\
\text { nitrogen, } \\
\text { filtered } \\
\text { (mg/L-N) }\end{array}$ & $\begin{array}{l}\text { Ammonia } \\
\text { plus } \\
\text { organic } \\
\text { nitrogen, } \\
\text { unfiltered } \\
\text { (mg/L-N) }\end{array}$ & $\begin{array}{c}\text { Nitrate } \\
\text { plus } \\
\text { nitrite, } \\
\text { filtered } \\
\text { (mg/L-N) }\end{array}$ & $\begin{array}{l}\text { Nitrite, } \\
\text { filtered } \\
\text { (mg/L-N) }\end{array}$ & $\begin{array}{c}\text { Total nitro- } \\
\text { gen [nitrate } \\
+ \text { nitrite + } \\
\text { ammonia + } \\
\text { organic-N], } \\
\text { filtered, } \\
\text { analytically } \\
\text { determined } \\
\text { (mg/L-N) }\end{array}$ & $\begin{array}{c}\text { Total } \\
\text { nitrogen } \\
\text { [nitrate + } \\
\text { nitrite + } \\
\text { ammonia } \\
\text { + organic- } \\
\text { N], } \\
\text { filtered, } \\
\text { calcu- } \\
\text { lated } \\
\text { (mg/L-N) }\end{array}$ & $\begin{array}{c}\text { Total } \\
\text { nitrogen } \\
\text { [nitrate + } \\
\text { nitrite + } \\
\text { ammonia } \\
+ \text { organic- } \\
\text { N], } \\
\text { unfiltered, } \\
\text { calculated } \\
\text { (mg/L-N) }\end{array}$ & $\begin{array}{c}\text { Delta } \\
\text { nitrogen-15/ } \\
\text { nitrogen-14 } \\
\text { of ammonia, } \\
\text { filtered (per } \\
\text { mil) }\end{array}$ & $\begin{array}{c}\text { Delta } \\
\text { nitrogen-15/ } \\
\text { nitrogen-14 } \\
\text { of nitrate, } \\
\text { filtered (per } \\
\text { mil) }\end{array}$ & $\begin{array}{c}\text { Delta } \\
\text { oxygen-18/ } \\
\text { oxygen-16 } \\
\text { of nitrate, } \\
\text { water, } \\
\text { filtered } \\
\text { (per mil) }\end{array}$ \\
\hline \multicolumn{15}{|c|}{ Groundwater } \\
\hline $\begin{array}{l}\text { Temporary } \\
\text { well at } \\
\text { Fithian Ln }\end{array}$ & $6 / 20 / 2018$ & 0925 & Normal & 5.11 & 5.7 & 5.6 & $<0.040$ & 0.001 & - & - & - & 4.85 & - & - \\
\hline S115135.1 & $7 / 27 / 2018$ & 1100 & Normal & $<0.01$ & - & - & 4.29 & $<0.001$ & 4.45 & - & - & & & \\
\hline $\begin{array}{l}\text { Temporary } \\
\text { well at end } \\
\text { of Terbell } \\
\text { Lane }\end{array}$ & $7 / 27 / 2018$ & 1300 & Normal & 0.03 & - & - & $<0.040$ & 0.003 & 0.25 & - & - & & & \\
\hline $\begin{array}{l}\text { Temporary } \\
\text { well } 01- \\
\text { Maidstone } \\
\text { Club }\end{array}$ & $7 / 30 / 2018$ & 1030 & Normal & 0.91 & - & - & $<0.040$ & $<0.001$ & 1.18 & - & - & 8.46 & - & - \\
\hline $\begin{array}{l}\text { Temporary } \\
\text { well at } \\
\text { Davids Lane } \\
\text { (south) }\end{array}$ & $28 / 6 / 2018$ & 1120 & NA & $<0.01$ & - & - & $<0.040$ & $<0.001$ & $<0.05$ & - & - & & & \\
\hline $\begin{array}{l}\text { Temporary } \\
\text { well at } \\
\text { Davids Lane } \\
\text { (south) }\end{array}$ & $8 / 6 / 2018$ & 1130 & Normal & $<0.01$ & - & - & 2.41 & 0.047 & 2.66 & - & - & - & 10.1 & 6.80 \\
\hline $\begin{array}{l}\text { Temporary } \\
\text { well near } \\
\text { Davids Lane } \\
\text { (north) }\end{array}$ & $8 / 7 / 2018$ & 0945 & Normal & $<0.01$ & - & - & 7.66 & $<0.001$ & 8.29 & - & - & - & 6.95 & -0.09 \\
\hline
\end{tabular}

'Sequential replicate sample collected.

2Field equipment blank. 
Table 4. Concentrations of phosphorus collected in the Hook Pond watershed, East Hampton, New York.

[Concentrations of nutrients in surface water and groundwater determined by U.S. Geological Survey National Water Quality Laboratory schedules 2702 and 2755 , respectively. Sample event denotes conditions under which a sample was collected and whether it is considered a storm or nonstorm (normal) sample. mg/L-P, milligram per liter as phosphorus; —, not analyzed; <, less than; NA, not applicable.]

\begin{tabular}{|c|c|c|c|c|c|c|}
\hline Site name & Sample date & $\begin{array}{c}\text { Sample } \\
\text { time }\end{array}$ & $\begin{array}{c}\text { Sample } \\
\text { event }\end{array}$ & $\begin{array}{c}\text { Orthophosphate, } \\
\text { filtered } \\
\text { (mg/L-P) }\end{array}$ & $\begin{array}{c}\text { Phosphorus, } \\
\text { filtered } \\
\text { (mg/L-P) }\end{array}$ & $\begin{array}{c}\text { Phosphorus, } \\
\text { unfiltered } \\
\text { (mg/L-P) }\end{array}$ \\
\hline \multicolumn{7}{|c|}{ Surface water } \\
\hline \multirow[t]{3}{*}{ Hook Pond (site 10) } & $11 / 21 / 2017$ & 1130 & Normal & $<0.004$ & 0.007 & 0.09 \\
\hline & $3 / 15 / 2018$ & 1020 & Normal & $<0.004$ & 0.007 & 0.079 \\
\hline & $7 / 23 / 2018$ & 1015 & Normal & $<0.004$ & 0.009 & 0.057 \\
\hline \multirow{13}{*}{ Hook Pond (site 3 ) } & $8 / 8 / 2017$ & 1030 & Normal & $<0.004$ & 0.006 & 0.06 \\
\hline & $8 / 15 / 2017$ & 1040 & Normal & $<0.004$ & 0.008 & 0.061 \\
\hline & $8 / 22 / 2017$ & 1058 & Normal & $<0.004$ & 0.008 & 0.062 \\
\hline & $8 / 29 / 2017$ & 1028 & Normal & $<0.004$ & 0.008 & 0.068 \\
\hline & $10 / 11 / 2017$ & 1110 & Normal & $<0.004$ & 0.008 & 0.038 \\
\hline & $10 / 26 / 2017$ & 1055 & Normal & $<0.004$ & 0.008 & 0.051 \\
\hline & $12 / 4 / 2017$ & 1305 & Normal & $<0.004$ & 0.007 & 0.052 \\
\hline & $2 / 8 / 2018$ & 1215 & Normal & $<0.004$ & 0.007 & 0.067 \\
\hline & $4 / 11 / 2018$ & 1130 & Normal & $<0.004$ & 0.004 & 0.03 \\
\hline & $5 / 2 / 2018$ & 1230 & Normal & $<0.004$ & 0.006 & 0.045 \\
\hline & $15 / 2 / 2018$ & 1231 & Normal & $<0.004$ & 0.005 & 0.041 \\
\hline & $5 / 17 / 2018$ & 1245 & Storm & $<0.004$ & 0.008 & 0.092 \\
\hline & $5 / 29 / 2018$ & 1200 & Normal & $<0.004$ & 0.008 & 0.073 \\
\hline Hook Pond (site 7) & $3 / 15 / 2018$ & 1145 & Normal & $<0.004$ & 0.005 & 0.03 \\
\hline \multirow[t]{4}{*}{ Fithian Lane } & $1 / 10 / 2018$ & 1015 & Snowmelt & 0.034 & 0.044 & 0.116 \\
\hline & $6 / 21 / 2018$ & 1100 & Storm & 0.03 & 0.05 & 0.104 \\
\hline & $7 / 6 / 2018$ & 1150 & Storm & 0.303 & 0.38 & 0.53 \\
\hline & $8 / 7 / 2018$ & 1045 & Normal & 0.018 & 0.021 & 0.067 \\
\hline \multirow[t]{2}{*}{ Huntting Lane } & $1 / 10 / 2018$ & 1050 & Snowmelt & $<0.004$ & $<0.003$ & 0.01 \\
\hline & $6 / 21 / 2018$ & 1030 & Storm & 0.012 & 0.016 & 0.028 \\
\hline Davids Lane (north) & $6 / 21 / 2018$ & 1000 & Storm & 0.02 & 0.027 & 0.057 \\
\hline \multirow[t]{3}{*}{ Davids Lane (south) } & $1 / 10 / 2018$ & 1120 & Snowmelt & 0.03 & 0.028 & 0.091 \\
\hline & $6 / 21 / 2018$ & 0930 & Storm & 0.022 & 0.036 & 0.088 \\
\hline & $8 / 7 / 2018$ & 1050 & Normal & 0.012 & 0.019 & 0.099 \\
\hline
\end{tabular}


Table 4. Concentrations of phosphorus collected in the Hook Pond watershed, East Hampton, New York.-Continued

[Concentrations of nutrients in surface water and groundwater determined by U.S. Geological Survey National Water Quality Laboratory schedules 2702 and 2755 , respectively. Sample event denotes conditions under which a sample was collected and whether it is considered a storm or nonstorm (normal) sample. $\mathrm{mg} / \mathrm{L}-\mathrm{P}$, milligram per liter as phosphorus; —, not analyzed; <, less than; NA, not applicable.]

\begin{tabular}{|c|c|c|c|c|c|c|}
\hline Site name & Sample date & $\begin{array}{c}\text { Sample } \\
\text { time }\end{array}$ & $\begin{array}{c}\text { Sample } \\
\text { event }\end{array}$ & $\begin{array}{c}\text { Orthophosphate, } \\
\text { filtered } \\
\text { (mg/L-P) }\end{array}$ & $\begin{array}{c}\text { Phosphorus, } \\
\text { filtered } \\
\text { (mg/L-P) }\end{array}$ & $\begin{array}{c}\text { Phosphorus, } \\
\text { unfiltered } \\
\text { (mg/L-P) }\end{array}$ \\
\hline \multicolumn{7}{|c|}{ Surface water-Continued } \\
\hline \multirow[t]{2}{*}{ Dunemere Lane } & $1 / 10 / 2018$ & 1210 & Snowmelt & 0.017 & 0.017 & 0.072 \\
\hline & $6 / 21 / 2018$ & 0830 & Storm & 0.012 & 0.013 & 0.036 \\
\hline \multicolumn{7}{|c|}{ Groundwater } \\
\hline Temporary well at Fithian Ln & $6 / 20 / 2018$ & 0925 & Normal & $<0.004$ & $<0.003$ & 0.005 \\
\hline S115135.1 & $7 / 27 / 2018$ & 1100 & Normal & $<0.004$ & - & - \\
\hline Temporary well at end of Terbell Lane & $7 / 27 / 2018$ & 1300 & Normal & $<0.004$ & - & - \\
\hline Temporary well near Davids Lane (north) & $8 / 7 / 2018$ & 0945 & Normal & $<0.004$ & - & - \\
\hline
\end{tabular}

${ }^{1}$ Sequential replicate sample collected.

2Field equipment blank.

In addition to elevated nutrient concentrations (tables 3 and 4), 27 of the 58 wastewater-indicator compounds were detected in at least one of the surface-water samples collected during two storm events (table 5). Stormwater samples collected at Fithian Lane, Dunemere Lane, and Hook Pond site 4 (which is the mouth of the tributary that drains Town Pond) indicate influences from stormwater runoff and human influences, including septic. The most commonly detected compounds were 3-methyl- $1 H$-indole (skatole, a chemical found in feces), camphor (a fragrance), and caffeine. $N, N$-diethyl- $m$-toluamide (DEET; insect repellant) was detected in every sample; however, there is evidence from previous field and laboratory blanks that these values may not be true environmental detections and therefore not considered a positive detection for this assessment. The number of wastewater-indicator compounds detected in the summer sample collected at Fithian Lane and the spring sample collected at Dunemere Lane were 21 and 14, respectively (table 5). The highest concentrations of these compounds were detected in the sample collected at Fithian Lane as the initial runoff was entering the stream from the storm sewer-the concentrations of caffeine $(8.72 \mu \mathrm{g} / \mathrm{L})$ and skatole $(4.74 \mu \mathrm{g} / \mathrm{L})$ were the two highest of the study (table 5). It is possible that concentrations for these compounds were higher but that other compounds and dissolved organics suppressed the signal (that is, matrix interferences are suggested because of a lower surrogate recovery for that sample; table 5). Concentrations of wastewater-indicator compounds introduced at Fithian
Lane are likely diluted from groundwater contributions as contaminants move downstream. The Dunemere Lane storm sample collected on June 21, 2018, was following rain that began several hours prior, whereas the sample on July 6 , 2018, was collected an hour after the first flush and may only represent stormwater runoff from the adjacent roadways.

\section{Groundwater Quality Adjacent to Hook Pond}

Nutrients and wastewater-indicator compounds were assessed in six and three wells, respectively (tables 3-5); with five of the six wells being temporary shallow piezometers. Orthophosphate concentrations in the groundwater samples were below the detection limit of $0.004 \mathrm{mg} / \mathrm{L}$ as phosphorus in all groundwater samples. Concentrations of wastewaterindicator compounds were below detection limits in samples from the three wells, suggesting that these organic compounds associated with septic leaching and road runoff are not discharging to Hook Pond through the shallow groundwater. Factors including low to medium population density ( $>0.5$-acre parcels), microbial degradation, and adsorption likely play a role in the limited mobility of these compounds (Fairbairn and others, 2016). Further, alternate means of collecting groundwater, such as passive sampling at depth over a course of weeks, may indicate that some of these contaminants are present, just at concentrations less than the detection limits of the current method. 


\section{$\boldsymbol{A}$}
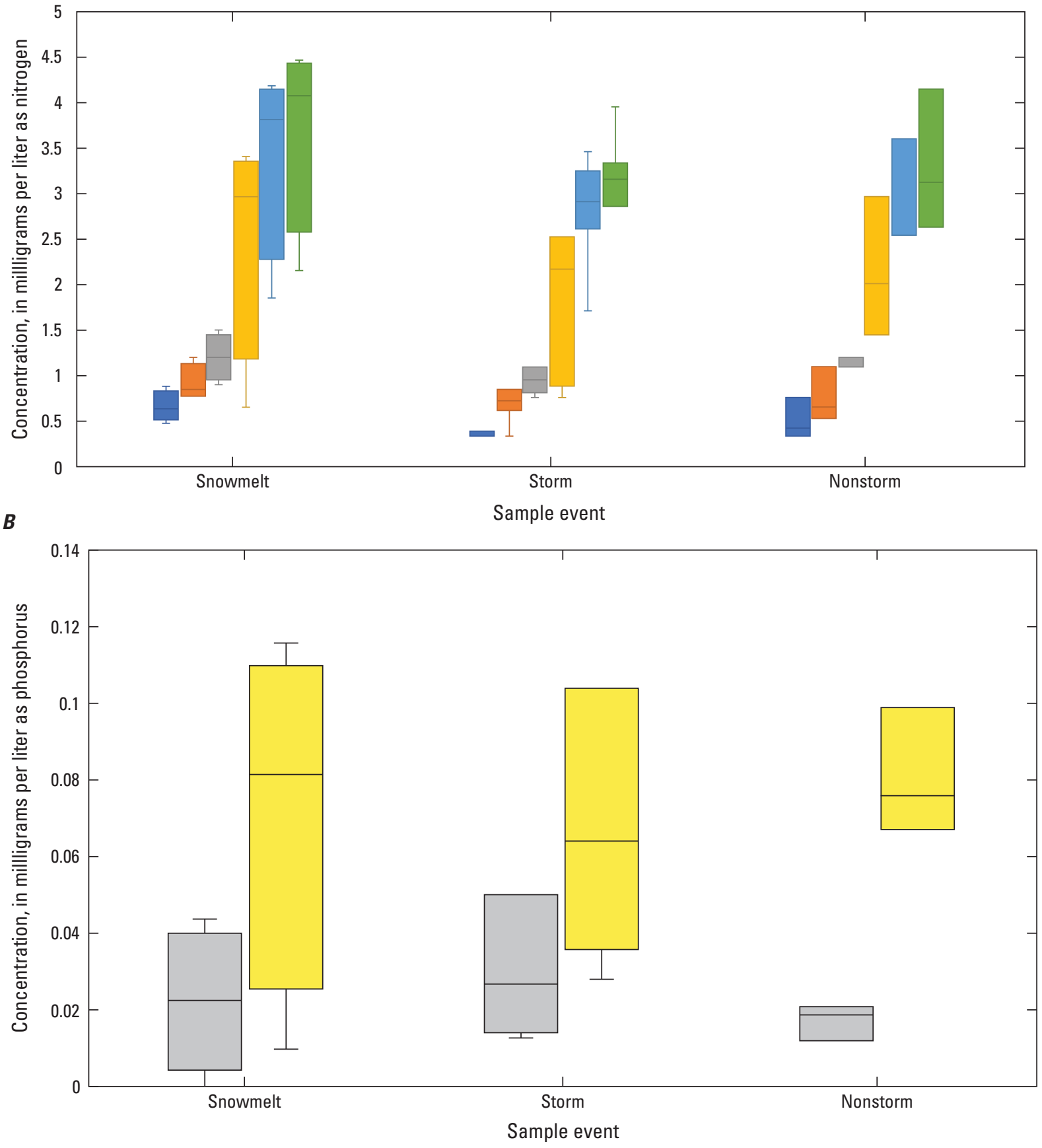

EXPLANATION

Ammonia-Filtered

Ammonia plus organic nitrogen-Filtered

Ammonia plus organic nitrogen-Unfiltered

Nitrate plus nitrite-Filtered

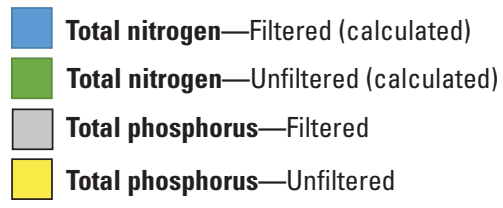

Figure 11. Comparisons of snowmelt, storm, and nonstorm sample events from samples collected from all sites along Hook Pond Dreen (see table 6 for the list of sites that represent each event), East Hampton, New York. $A$, Nitrogen species. $B$, Phosphorus species. Sample size for snowmelt is 4 , for storm is 7 , and for nonstorm is 3 . 


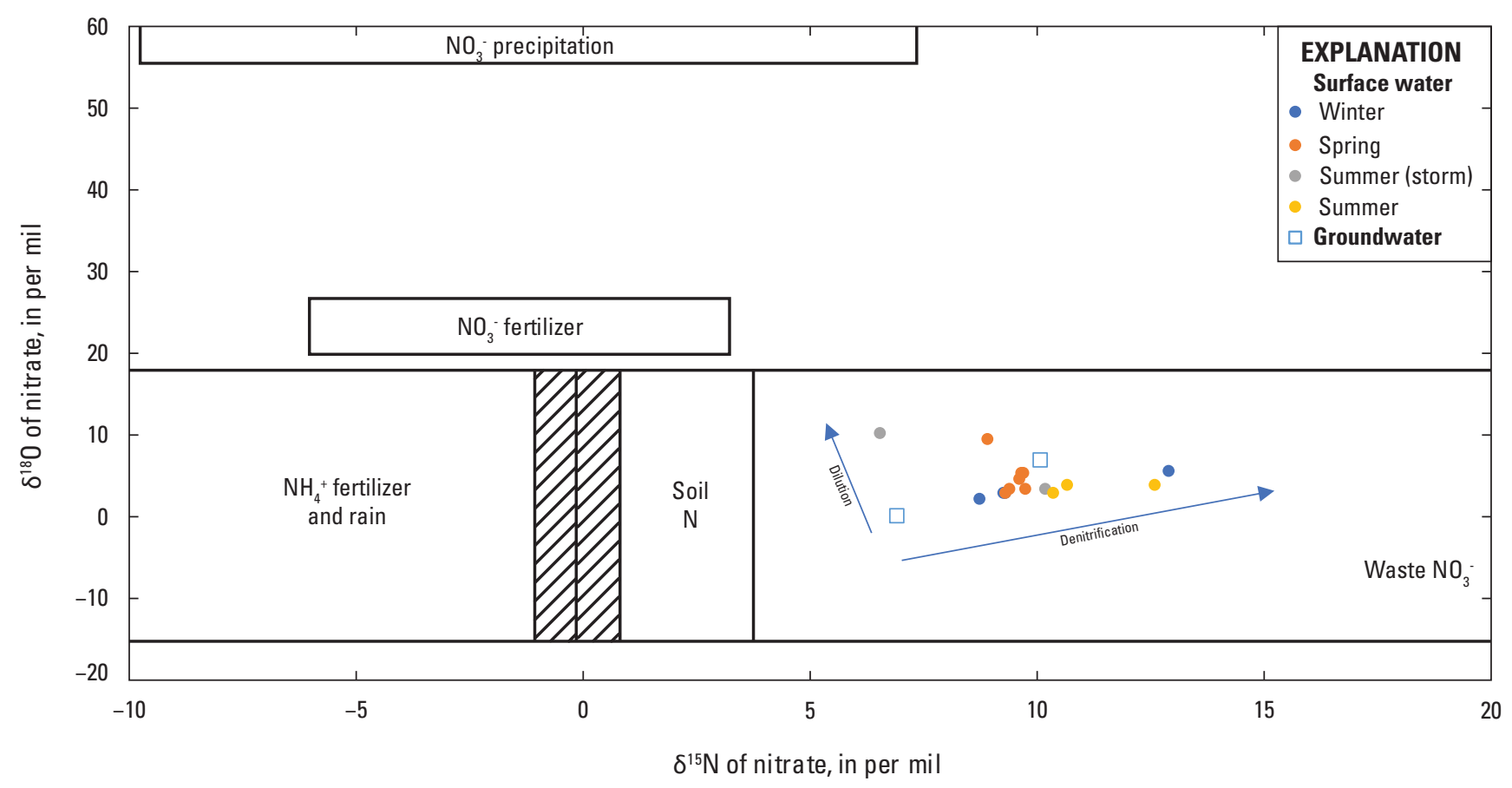

Figure 12. Stable isotope of oxygen-18 $(180)$ and nitrogen-15 $(15 \mathrm{~N})$ of nitrate in surface-water and groundwater samples collected throughout the Hook Pond watershed, East Hampton, New York. Groups of isotope ranges are modified from Burns and others (2009) and represent likely sources of nitrate to the groundwater (and subsequently to Hook Pond Dreen through groundwater seepage). Differences in isotope ratios at sites throughout the year can be described as contributions from denitrification and dilution of rainwater. Areas filled with diagonal lines represent overlap between the region of fertilizer and rain and the region of soil. $\mathrm{N}$, nitrogen; $\mathrm{NO}_{3}{ }^{-}$, nitrate; $\mathrm{NH}_{4}{ }^{+}$, ammonium.

Nitrogen concentrations in groundwater around the pond vary, and speciation depends on oxygen concentrations. Shallow groundwater collected adjacent to the stream banks at Fithian Lane, areas both north and south of Davids Lane, at a point on the western shoreline of Hook Pond, and the end of Terbell Lane (fig. 4B) differed in dissolved oxygen and nutrient concentrations (appendix table 2.4). The depth of the temporary wells ranged from 4 to $7 \mathrm{ft}$ below surface, a depth at which sampled groundwater is likely influencing the adjacent surface waters. Low concentrations of dissolved oxygen and elevated concentrations of ammonium were observed at Fithian Lane and on the north shore of Hook Pond at Maidstone Club (fig. $2 B$ and appendix table 2.4). The highest concentration of ammonium $(5.11 \mathrm{mg} / \mathrm{L}$ as nitrogen) observed in this study was detected in shallow groundwater with low dissolved oxygen at Fithian Lane and may be the result of upland land use (for example, OWDS and fertilizer application) and part of a stratified nitrogen plume (Stoliker and others, 2016). Isotope values for $\delta^{15} \mathrm{~N}$ of ammonium at the temporary wells at Fithian Lane and Maidstone Club were 4.85 and 8.46 per mil, respectively, suggesting an enriched nitrogen signature likely the result of septic influence (Abbene, 2010).
Conversely, groundwater samples collected adjacent to Hook Pond Dreen north of Davids Lane represented the highest nitrate concentration in this study $(7.66 \mathrm{mg} / \mathrm{L}$ as nitrogen), which are higher than those observed in the shallow groundwater adjacent to Davids Lane $(2.41 \mathrm{mg} / \mathrm{L}$ as nitrogen $)$ and the deeper well S115135.1 (4.29 mg/L; well location in fig. 4B; similar to those in samples collected in 2000-2004). Total nitrogen (unfiltered) concentrations in the six groundwater samples ranged from 0.25 to $8.29 \mathrm{mg} / \mathrm{L}$ as nitrogen (tables 3 and 4). This wide range in nitrogen concentration and difference in speciation along the groundwater flowpath and within the immediate discharge zone for Hook Pond could be used when considering spatial variability to improve future load calculations. Isotope values of groundwater from the two temporary wells adjacent to Davids Lane indicated different degrees of denitrification and different sources, with a $\delta^{15} \mathrm{~N}$ and $\delta^{18} \mathrm{O}$ of $\mathrm{NO}_{3}{ }^{-}$of 6.95 and -0.09 per mil north of Davids Lane and 10.1 and 6.80 per mil just south of the pavement at Davids Lane, respectively (fig. 12). 
Table 5. Concentrations of wastewater-indicator compounds, U.S. Geological Survey National Water Quality Laboratory schedule 1433, collected in the Hook Pond watershed, East Hampton, New York.

[Samples collected at Dunemere Lane, Hook Pond (site 4), and Fithian Lane were during storm events. Samples were filtered in the field and results represent recoverable concentrations. Only compounds with at least one detection and the surrogate recoveries are shown; see table 1.1 (appendix 1) for a complete list of analytes for this method. Sample events: Storm, sample collected under storm conditions; Normal, sample collected under nonstorm conditions. <, less than;

E, estimated; M, detected but not quantified]

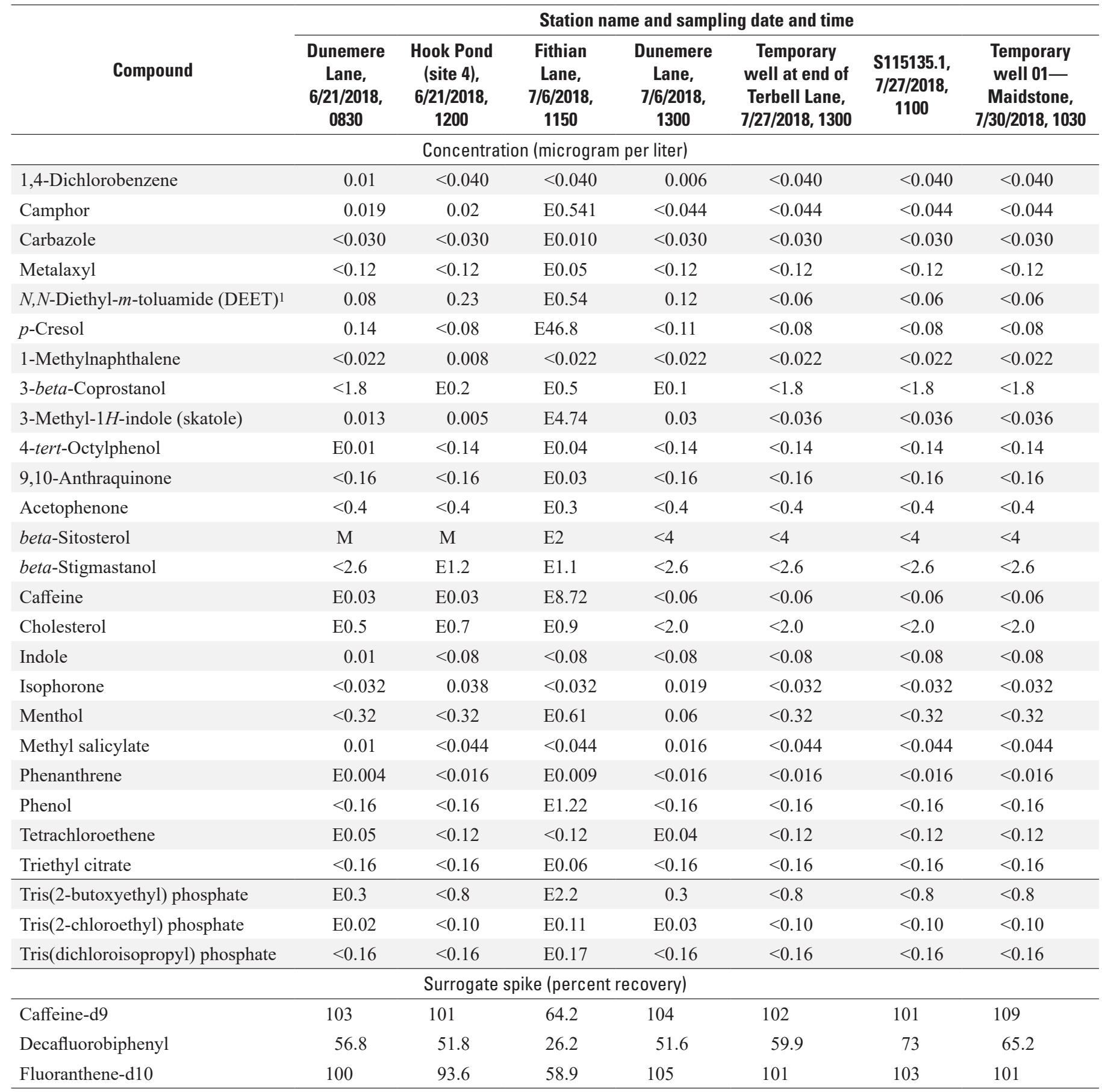

1There is evidence from previous field and laboratory blanks that results for DEET may not be true environmental detections. 


\section{Sources of Fecal Contamination to Hook Pond}

Seventeen sample sets were collected from Hook Pond and Hook Pond Dreen and from shallow groundwater adjacent to these surface waters (fig. 2). Samples were collected in the winter during a period of snowmelt, before and after a spring storm, and during the summer. Coliphage and Bacteroides results were compared within and across sampling events. Fecal indicator bacteria data were analyzed to assess potential correlations between the types of indicator bacteria and specific MST markers. Results from the individual analyses and comparison of coliphage and Bacteroides data provided insight into sources and distribution of pathogens to Hook Pond. Results for shallow groundwater adjacent to Hook Pond Dreen and Hook Pond indicated that concentrations of fecal indicator bacteria and Bacteroides were below detection limits and that coliphage results were negative for all groups (table 6), suggesting limited mobility of bacterial pathogens in the subsurface soils surrounding Hook Pond. However, fecal indicator bacteria detections in surface-water grab samples were positive for all but one site, and coliphage and MST marker results were positive for multiple markers (table 6).

In general, MST results along Hook Pond Dreen during both storm and nonstorm events illustrate the presence of waterfowl and dogs with the co-occurrence of bird (GFD) and dog (BacCan) markers. Most samples along Hook Pond Dreen had concentrations of enterococci, E. coli, and fecal coliform at or near the detection limits for the respective methods. Many of the fecal indicator bacteria concentrations were above the EPA beach action value for enterococci of 60 colony forming units per $100 \mathrm{~mL}$ (roughly equivalent to MPN/100 mL; EPA, 2012) and consistently above $49 \mathrm{MPN} / 100 \mathrm{~mL}$ for fecal coliform, which is the concentration that no more than 10 percent of samples collected under the U.S. Food and Drug Administration National Shellfish Sanitation Program can exceed (FDA, 2017). Results from the coliphage analyses indicate positive detections of the virus in all 12 winter and spring wet-weather samples, whereas the nonstorm summer samples showed only one positive detection and no marker present (table 6). However, coliphages were not observed in any groundwater samples. Following enrichment of these samples, 11 had markers in group I (other animals), and the sample from Fithian Lane during the winter snowmelt had a group III (human) marker detected. In samples collected immediately before and just after a spring rainstorm, positive detections for coliphages were identified as animal (nonhuman) markers and correlate with high fecal indicator bacteria concentrations (table 6).

Of the 17 sample sets collected for MST analyses, 10 were submitted for Bacteroides analysis to supplement coliphage data. Of the four Bacteroides markers assessed in this study, the BacCan (domestic dog) marker was detected most frequently ( 90 percent of samples), with maximum concentration of roughly $1,400,000$ copies/100 $\mathrm{mL}$ at Davids Lane (south) (table 6). The highest concentrations and frequency of detection (100 percent) were at the Davids Lane south site and were independent of season or flow condition. The GFD (birds) marker was detected in 60 percent of the samples collected, with a maximum concentration almost 9,000 copies $/ 100 \mathrm{~mL}$, and 40 percent of the detections of GFD occurred at the Davids Lane south site. The HF183 (human) marker was detected in 40 percent of the samples, with three of the four in the spring storm samples around Davids Lane and in Hook Pond (table 6). Only one sample was positive for Rum2Bac (ruminants), during the spring storm event at Davids Lane north site, and it had a concentration of 4,300 copies $/ 100 \mathrm{~mL}$. The relative proportions of the four MST markers detected along Hook Pond Dreen are comparable to those detected along the shore of nearby Georgica Pond in 2016 by Gobler and others (2018); however, comparing the number of marker copies across types is not as useful as comparing the relative abundance among the same marker type because the methods for each marker differ.

\section{Synthesis of Results}

Data collected and interpreted for this study, in part, fill gaps outlined in the Hook Pond Water Quality Improvement Project (Lombardo Associates, Inc., 2015). The "Recommended Monitoring Program and Water Quality Restoration Goals" section of the Water Quality Improvement Project was referenced while developing a sampling strategy, in consultation with the Village of East Hampton, based on resources available. In addition to filling gaps, the strategy was developed to assess current and seasonal conditions related to nutrients, physicochemical constituents, and pathogens to further inform management decisions and provide a baseline for future research and monitoring of the Hook Pond and its watershed. The following synthesis of results contextualizes the data in relation to current (2020) conditions and provides guidance for application of the data.

\section{Contributions of Hook Pond Watershed}

The extent to which contaminants in groundwater and stormwater conveyances within the Hook Pond watershed affect water quality was measured during this study by using key constituents such as nutrients (including isotope analysis of nitrogen), wastewater-indicator compounds, and specific conductance. Along Hook Pond Dreen, concentrations of nitrogen and phosphorus at Fithian Lane become diluted downstream prior to reaching Hook Pond. Elevated ammonia concentrations at Fithian Lane can be attributed to anoxic (that is, low dissolved oxygen) groundwater contributing to base flow, whereas at Davids Lane, ammonia is lower and nitrate concentrations are higher because of influence from the groundwater surrounding Hook Pond Dreen (which is oxic and high in nitrate; tables 3 and 4, appendix table 2.4) and 


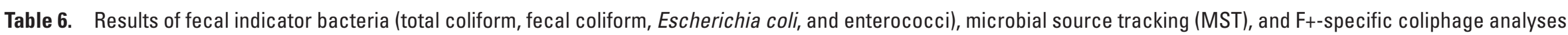
from samples collected for microbial source tracking within the Hook Pond watershed, East Hampton, New York.

[For coliphages, amplification profile must cross an Rn of 0.1 by cycle 30 in both reactions to be called group positive. Some quality-control samples are from concurrent U.S. Geological Survey studies in other

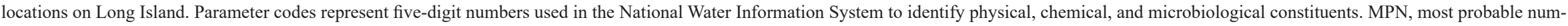
ber; mL, milliliter; E. Coli, Escherichia coli; col, colonies; >, greater than; <, less than; - , not analyzed; NA, not assayed; none, no group detected; DEC, Department of Environmental Conservation (New York State)]

\begin{tabular}{|c|c|c|c|c|c|c|c|c|c|c|c|}
\hline \multirow[b]{2}{*}{ Site } & \multirow[b]{2}{*}{ Date } & \multicolumn{4}{|c|}{ Fecal indicator bacteria } & \multicolumn{2}{|c|}{ F+-specific coliphages } & \multicolumn{4}{|c|}{ Microbial source tracking markers } \\
\hline & & $\begin{array}{c}\text { Total } \\
\text { coliform } \\
\text { (MPN/ } \\
100 \mathrm{~mL} \text { ) }\end{array}$ & $\begin{array}{c}\text { Fecal } \\
\text { coliform } \\
\text { (MPN/ } \\
100 \mathrm{~mL} \text { ) }\end{array}$ & $\begin{array}{c}\text { E. coli } \\
\text { (MPN/ } \\
100 \mathrm{~mL})\end{array}$ & $\begin{array}{l}\text { Enterococci } \\
\text { (col/100 mL) }\end{array}$ & $\begin{array}{l}\text { Coliphage } \\
\text { presence }\end{array}$ & Group & $\begin{array}{c}\text { HF183 } \\
\text { (copies per } \\
100 \mathrm{~mL} \text { ) }\end{array}$ & $\begin{array}{l}\text { Rum2Bac } \\
\text { (copies per } \\
100 \mathrm{~mL} \text { ) }\end{array}$ & $\begin{array}{c}\text { GFD } \\
\text { (copies per } \\
100 \mathrm{~mL} \text { ) }\end{array}$ & $\begin{array}{c}\text { BacCan } \\
\text { (copies per } \\
100 \mathrm{~mL} \text { ) }\end{array}$ \\
\hline \multicolumn{12}{|c|}{ Snowmelt } \\
\hline Fithian Lane & $1 / 10 / 2018$ & $>16,000$ & 40 & 98 & 238 & Positive & III (human) & $<2,400$ & $<4,200$ & $<1,200$ & 35,000 \\
\hline Huntting Lane & $1 / 10 / 2018$ & 80 & 40 & 411 & 11 & Positive & I (other animal) & - & - & - & - \\
\hline Davids Lane (south) & $1 / 10 / 2018$ & 800 & 500 & 1120 & 50 & Positive & I (other animal) & $<1,100$ & $<1,900$ & 2,000 & $1,400,000$ \\
\hline Dunemere Lane & $1 / 10 / 2018$ & 1,700 & 1,700 & $>2,420$ & 613 & Positive & I (other animal) & - & - & - & - \\
\hline \multicolumn{12}{|c|}{ Spring prestorm } \\
\hline Davids Lane (north) & $6 / 20 / 2018$ & 500 & 170 & 727 & $>800$ & Positive & I (other animal) & - & - & - & - \\
\hline Davids Lane (south) & $6 / 20 / 2018$ & 2,400 & 2,400 & 1,733 & 540 & Positive & I (other animal) & $<1,500$ & $<2,500$ & 4,500 & 190,000 \\
\hline \multicolumn{12}{|c|}{ Spring storm } \\
\hline Fithian Lane & $6 / 21 / 2018$ & 9,000 & 9,000 & 1,120 & $>800$ & Positive & I (other animal) & $<2,200$ & $<3,800$ & $<1,100$ & 47,000 \\
\hline Huntting Lane & $6 / 21 / 2018$ & 3,000 & 2,400 & 1,046 & $>800$ & Positive & I (other animal) & - & - & - & - \\
\hline Davids Lane (north) & $6 / 21 / 2018$ & 2,400 & 2,400 & 1,046 & $>800$ & Positive & I (other animal) & $\mathrm{a}, \mathrm{b} 4,400$ & $\mathrm{c}, \mathrm{d} 4,300$ & 3,500 & $\mathrm{c}, \mathrm{e} 93,000$ \\
\hline Davids Lane (south) & $6 / 21 / 2018$ & 9,000 & 2,400 & 1,120 & $>800$ & Positive & I (other animal) & a,b,e 1,500 & $<3,800$ & 7,300 & 500,000 \\
\hline Dunemere Lane & $6 / 21 / 2018$ & 2,400 & 2,400 & $>2,420$ & $>800$ & Positive & I (other animal) & - & - & - & - \\
\hline Hook Pond (site 3) & $6 / 21 / 2018$ & 70 & 70 & 10 & 60 & Positive & I (other animal) & a,b 1,100 & $<3,800$ & $<1,100$ & $\mathrm{c}, \mathrm{e} 3,700$ \\
\hline \multicolumn{12}{|c|}{ Summer nonstorm } \\
\hline Fithian Lane & $8 / 7 / 2018$ & 5,000 & 3,000 & 1,120 & $>800$ & Negative & NA & 2,800 & $<1,900$ & $<540$ & $<780$ \\
\hline Huntting Lane & $8 / 7 / 2018$ & 5,000 & 1,100 & 1,413 & $>800$ & Negative & NA & - & - & - & - \\
\hline Davids Lane (south) & $8 / 7 / 2018$ & $>16,000$ & $>16,000$ & $>2,419$ & $>800$ & Negative & NA & $<360$ & $<1,900$ & 9,000 & 840,000 \\
\hline Dunemere Lane & $8 / 7 / 2018$ & 3,000 & 3,000 & 1,986 & $>800$ & Positive & None & $<360$ & $<1,900$ & 1,500 & 47,000 \\
\hline Terbell Lane & $8 / 7 / 2018$ & 40 & $<20$ & 32.7 & $>800$ & Negative & NA & - & - & - & - \\
\hline \multicolumn{12}{|c|}{ Groundwater } \\
\hline $\begin{array}{l}\text { Temporary well at } \\
\text { Fithian Lane }\end{array}$ & $6 / 20 / 2018$ & $<20$ & $<20$ & $<1$ & $<4$ & Negative & NA & $<1,100$ & $<1,900$ & $<540$ & $<1,200$ \\
\hline $\begin{array}{l}\text { Temporary well at } \\
\text { Davids Lane (south) }\end{array}$ & $8 / 6 / 2018$ & $<20$ & $<20$ & $<1$ & $<4$ & Negative & NA & $<360$ & $<1,900$ & $<540$ & $<780$ \\
\hline $\begin{array}{l}\text { Temporary well near } \\
\text { Davids Lane (north) }\end{array}$ & $8 / 7 / 2018$ & $<20$ & $<20$ & $<1$ & $<4$ & Negative & NA & - & - & - & - \\
\hline
\end{tabular}

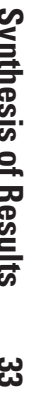




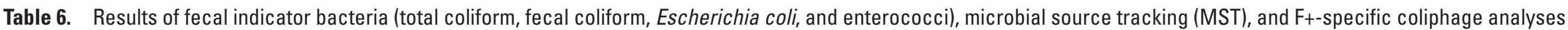
from samples collected for microbial source tracking within the Hook Pond watershed, East Hampton, New York.-Continued

[For coliphages, amplification profile must cross an Rn of 0.1 by cycle 30 in both reactions to be called group positive. Some quality-control samples are from concurrent U.S. Geological Survey studies in other

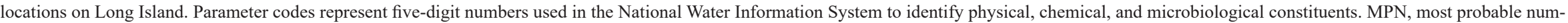

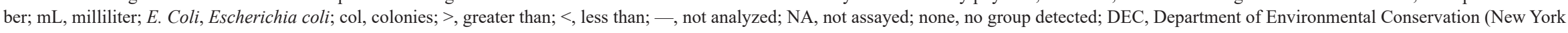
State); MST, microbial source tracking]

\begin{tabular}{|c|c|c|c|c|c|c|c|c|c|c|c|}
\hline \multirow[b]{2}{*}{ Site } & \multirow[b]{2}{*}{ Date } & \multicolumn{4}{|c|}{ Fecal indicator bacteria } & \multicolumn{2}{|c|}{ F+-specific coliphages } & \multicolumn{4}{|c|}{ Microbial source tracking markers } \\
\hline & & $\begin{array}{c}\text { Total } \\
\text { coliform } \\
\text { (MPN/ } \\
100 \mathrm{~mL} \text { ) }\end{array}$ & 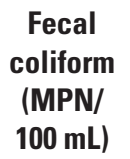 & $\begin{array}{c}\text { E. coli } \\
\text { (MPN/ } \\
100 \mathrm{~mL})\end{array}$ & $\begin{array}{l}\text { Enterococci } \\
\text { (col/100 mL) }\end{array}$ & $\begin{array}{l}\text { Coliphage } \\
\text { presence }\end{array}$ & Group & $\begin{array}{c}\text { HF183 } \\
\text { (copies per } \\
100 \mathrm{~mL} \text { ) }\end{array}$ & $\begin{array}{l}\text { Rum2Bac } \\
\text { (copies per } \\
100 \mathrm{~mL} \text { ) }\end{array}$ & $\begin{array}{c}\text { GFD } \\
\text { (copies per } \\
100 \mathrm{~mL} \text { ) }\end{array}$ & $\begin{array}{l}\text { BacCan } \\
\text { (copies per } \\
100 \mathrm{~mL} \text { ) }\end{array}$ \\
\hline \multicolumn{12}{|c|}{ Known source } \\
\hline $\begin{array}{l}\text { Human at Sag Harbor } \\
\text { STP }\end{array}$ & $6 / 25 / 2018$ & - & - & - & - & Positive & $\begin{array}{l}\text { II (human/ } \\
\text { swine), III } \\
\text { (human) }\end{array}$ & $1,300,000,000$ & $<300,000$ & $<86,000$ & $24,000,000$ \\
\hline $\begin{array}{l}\text { Duck/goose at Davids } \\
\text { Lane }\end{array}$ & $8 / 7 / 2018$ & - & - & - & - & Negative & NA & $<100,000$ & $<820,000$ & $45,000,000$ & $<360,000$ \\
\hline Deer at Orient & $8 / 30 / 2018$ & - & - & - & - & Negative & NA & $<13,000$ & 900,000 & $<31,000$ & $<45,000$ \\
\hline \multicolumn{12}{|c|}{ Quality control } \\
\hline $\begin{array}{l}\text { Davids Lane (south) } \\
\text { equipment blank }\end{array}$ & $8 / 6 / 2018$ & $<20$ & $<20$ & $<1$ & $<4$ & Negative & NA & - & - & - & - \\
\hline DEC MST replicate 1 & $6 / 12 / 2018$ & 1,300 & 1,300 & 48.8 & 100 & Positive & I (other animal) & $\mathrm{a}, \mathrm{b}, \mathrm{e} 1,500$ & $<2,500$ & $<720$ & 4,300 \\
\hline DEC MST replicate 2 & $6 / 12 / 2018$ & 1,300 & 1,300 & 38.3 & 100 & Positive & I (other animal) & $\mathrm{a}, \mathrm{b}, \mathrm{d} 1,500$ & $<2,500$ & $<720$ & $\mathrm{c}, \mathrm{e} 2,400$ \\
\hline DEC MST blank water & $6 / 18 / 2018$ & $<20$ & $<20$ & $<1$ & $<4$ & Negative & NA & $<1,300$ & $<1,900$ & $<540$ & $<1,200$ \\
\hline DEC MST replicate 2 & $7 / 18 / 2018$ & 16,000 & 3,000 & - & - & Positive & $\begin{array}{l}\text { II (human/ } \\
\text { swine) }\end{array}$ & 840 & $<1,900$ & $<540$ & 3,700 \\
\hline DEC MST replicate 2 & $7 / 18 / 2018$ & 9,000 & 3,000 & - & - & Positive & $\begin{array}{l}\text { II (human/ } \\
\text { swine) }\end{array}$ & 2,400 & $<3,100$ & $<900$ & $\mathrm{c}, \mathrm{e} 12,000$ \\
\hline Parameter code & & 31,686 & 31,687 & 31,689 & 31,649 & 99,335 & $31,910-31,913$ & 68,203 & 31,808 & 31,810 & 68,206 \\
\hline
\end{tabular}

aValue-qualifer code V: result may be affected by contamination.

bValue-qualifer code c: contamination was found in a blank sample and was used to appropriately qualify associated samples.

cValue-qualifer code E: estimated.

dValue-qualifer code b: concentration is below the limit of quantification but above the limit of detection.

eValue-qualifer code $\sim$ : duplicate quantitative polymerase chain reaction results do not agree. 
from nitrification in the water column. Isotope ratios (fig. 12) represent sources of water to the stream, such as groundwater affected by OWDSs or manure application and influenced by denitrification (Duncan and others, 2017; Kendall and others, 2014). During precipitation events, enriched $\delta^{18} \mathrm{O}$ and depleted $\delta^{15} \mathrm{~N}$ together represent mixing from the atmosphere and contrast with groundwater ammonia nitrogen (Feinson and others, 2016; Kendall and Caldwell, 1998).

Storm samples collected along Hook Pond Dreen provided insight into the effect of runoff to water quality (tables 3-5). Of the two sets of storm samples, the first flush sample (grab sample collected at Fithian Lane roughly $20 \mathrm{ft}$ downstream from where the initial pulse of discolored water emerged from the outfall) collected on July 6, 2018, following a pulse of 0.1 inch of rain (and preceded by a dry period of 11 days at East Hampton Airport [KHTO]) was most revealing. Relatively high concentrations of personal care products (for example, caffeine and camphor), human biomolecules (3-beta-coprostanol), and solvents were detected (table 5). Of interest is the relatively high ratio of 3-beta-coprostanol to cholesterol of 0.7 (concentrations of $0.5 \mu \mathrm{g} / \mathrm{L}$ and $0.7 \mu \mathrm{g} / \mathrm{L}$, respectively), which can be indicative of human fecal waste (Marvin and others, 2001). Phosphorus concentrations were also 100 times higher under storm conditions than in groundwater at Fithian Lane $(0.53 \mathrm{mg} / \mathrm{L}$ as phosphorus at Fithian Lane versus $0.005 \mathrm{mg} / \mathrm{L}$ as phosphorus in adjacent groundwater) and roughly 10 times greater than under nonstorm conditions $(0.067 \mathrm{mg} / \mathrm{L}$ as phosphorus versus $0.005 \mathrm{mg} / \mathrm{L}$ as phosphorus; tables 3 and 4), indicating that along with the pulse of wastewater-indicator contaminants (table 5), the storm sewer is a major source of phosphorus to Hook Pond Dreen. Unlike ammonium, which undergoes oxidation (to nitrite and ultimately nitrate) and can become diluted downstream, phosphorus concentrations were greater at Davids Lane under nonstorm conditions, likely from the large waterfowl population immediately upstream.

Interestingly, specific conductance values at the two Davids Lane surface-water sites (north and south) suggest that a section of Hook Pond Dreen is less affected by landuse practices than Fithian Lane (appendix tables 2.2 and 2.3; high specific conductance in groundwater typically reflects land-use practices such as OWDSs, road salt, and fertilizers). High concentrations of bacteria (with sources determined to be waterfowl under nonstorm conditions and canine, waterfowl, ruminant [likely deer], and possibly human during storm conditions) indicate a shift in major contributors to poor water quality along Hook Pond Dreen. The two storm samples collected at Dunemere Lane on June 21 and July 6, 2018, 3-4 hours after the rain, resulted in 14 detections of wastewater indicators, compared to 10 detections in a sample collected about 1 hour after the rain. In the absence of storm discharge measurements, and assuming that most of the contaminants detected at Dunemere Lane originated from Fithian Lane, it appears (based on surface velocity observations and higher water-surface elevations) that Hook Pond Dreen streamflow during storms (high-flow conditions) is greater than $1 \mathrm{ft}^{3} / \mathrm{s}$, during which the contaminant pulse travels downstream and results in increased specific conductance as it carries salts and metals along with organic contaminants to Hook Pond.

The spike in specific conductance observed at the continuous water-quality monitoring site (Hook Pond site 10) in the winter of 2018 (fig. 6) is an example of changes in dissolved solids (that is, elements that increase specific conductance in water) that can be used as a proxy (a representative) for contamination pulses from known sources. Sodium and chloride (two components of road salt) are considered conservative elements (meaning they are typically not reactive in the water column or downstream) and can be used as tracers. In March 2018, the New York State Department of Transportation applied road salt to State Route 27 ahead of a series of winter storms, which subsequently was washed off following a rain event and snowmelt (no road salt was applied to village roads ahead of or during these storms). The resulting pulse likely began at the Fithian Lane storm sewer outfall. Values returned to the baseline about 35 days after the spike in specific conductance and following about 4.5 inches of rain (between March 4 and April 8, 2018; East Hampton Airport [KHTO]), which likely aided in the dilution of specific conductance.

Groundwater concentrations of nitrogen (nitrate, ammonium, and organic nitrogen [filtered]; tables 3 and 4) in shallow temporary wells contribute to Hook Pond and Hook Pond Dreen through base flow, whereas Town Pond has been described as being underlain by silt or clay, which limits groundwater discharge (Bill Hajek, Village of East Hampton, N.Y., oral commun., August, 2017), and therefore results in the need to pump groundwater into the pond to keep it from running dry in the summer months. Assuming the concentrations of nitrogen and phosphorus in the groundwater being pumped to Town Pond are similar to the concentrations measured in shallow groundwater around the shore of Hook Pond and adjacent to Hook Pond Dreen (tables 3 and 4), the relative contribution to the overall nutrient budget should not be affected.

Seasonal fluctuations in population of the Village of East Hampton - both residential and tourist - have been shown to be reflected in shallow groundwater quality (Fisher and others, 2016) and in wastewater treatment facilities (Vatovec and others, 2016). Previous estimates shown in the Water Quality Improvement Project using historical (2002-8) USGS data for Hook Pond were calculated on the basis of mean surface-water concentrations of total nitrogen (unfiltered) of $2.43 \mathrm{mg} / \mathrm{L}$ as nitrogen and total phosphorus (unfiltered) of $0.076 \mathrm{mg} / \mathrm{L}$ as phosphorus. Although these concentrations are noted as being estimates based on the limited data available at the time, the seasonal variability of nitrogen observed in this study (in which mean concentrations of total nitrogen [unfiltered] from samples collected from Hook Pond ranged from $1.28 \mathrm{mg} / \mathrm{L}$ as nitrogen in the summer to $3.24 \mathrm{mg} / \mathrm{L}$ as nitrogen in the winter [tables 3 and 4]) highlighted the need for the current set of data collected for this study. Furthermore, the speciation of the inorganic nitrogen constituents is important to consider because seasonal variability in nitrate most heavily 
influences the total nitrogen concentrations; mean concentrations of ammonia plus organic nitrogen (unfiltered) were roughly $1.0 \mathrm{mg} / \mathrm{L}$ as nitrogen regardless of season. Similarly, no significant difference in total phosphorus concentrations across seasons (the mean in each season was $0.06 \mathrm{mg} / \mathrm{L}$ as phosphorus) exists in samples collected from Hook Pond, though rain events did increase total phosphorus concentrations slightly within the pond and substantially at Fithian Lane (mean concentration of $0.10 \mathrm{mg} / \mathrm{L}$ as phosphorus during dryweather samples and $0.53 \mathrm{mg} / \mathrm{L}$ as phosphorus during storm samples [tables 3 and 4]). The year-round, high-frequency data collected for this study allow for a more accurate accounting of seasonal conditions, such as increased uptake by algae and fertilizer application in the late spring, summer, and early autumn (Suffolk County prohibits application of fertilizer on residential lawns between November 1 and April 1).

Furthermore, mean values can be used for each season at locations along Hook Pond Dreen to infer relative contributions of inputs, though more streamgage measurements are required to develop a rating necessary for accurate discharge measurements and load calculations.

\section{Current Hydrologic Conditions of Hook Pond}

The nitrogen and phosphorus data collected at Hook Pond site 3 were not significantly different from comparable (seasonal, nonstorm conditions) data collected by the USGS in 2001-8 ( $P=0.514)$. In the Water Quality Improvement Project (Lombardo Associates, Inc., 2015), the denitrification variable is used to align the predicted total nitrogen concentration of Hook Pond with that of the adjacent groundwater. The extent of seasonal changes in the rate of denitrification is evident by the 130-fold difference in nitrate concentrations between summer $(0.02 \mathrm{mg} / \mathrm{L}$ as nitrogen $)$ and winter $(2.6 \mathrm{mg} / \mathrm{L}$ as nitrogen $)$ in Hook Pond over 2017-18 (tables 3 and 4). Furthermore, variations in concentrations and dominant species of nitrogen in groundwater adjacent to Hook Pond Dreen and around the shoreline were observed during this study and can be used to more accurately define future accounting of the nitrogen budget. Although it is noted in the Water Quality Improvement Project that a nitrogen total maximum daily load is not necessarily needed for regulatory purposes, there is interest in studying the concentrations of nitrogen in freshwater systems as they relate to the formation of harmful cyanobacteria (Gobler and others, 2016; Graham and others, 2004).

It is suggested in the Water Quality Improvement Project that inputs of phosphorus to Hook Pond would be lower in the summer months, presumably because of the typically drier weather and use of phosphorus by phytoplankton. Although concentrations of total phosphorus in Hook Pond throughout the year are relatively stable, with a median of $0.06 \mathrm{mg} / \mathrm{L}$ as phosphorus, several of the highest concentrations of total phosphorus were measured in spring storm $(0.10 \mathrm{mg} / \mathrm{L}$ as phosphorus) and summer storm $(0.53 \mathrm{mg} / \mathrm{L}$ as phosphorus $)$ samples at Fithian Lane. The June 21, 2018, storm event also corresponded to elevated concentrations of total phosphorus $(0.095 \mathrm{mg} / \mathrm{L}$ as phosphorus) in Hook Pond (tables 3 and 4). Complicating this assessment is resuspension from storms and bioturbation that, in combination with lower dissolved oxygen at night and lower $\mathrm{pH}$ in the nonsummer months, could act as an internal loading source of phosphorus because of phosphate dissolution (Søndergaard and others, 2003). In addition, grass clippings and leaves from areas adjacent to and within the stormwater conveyance system have been shown to result in higher phosphorus concentrations in freshwater systems (Selbig, 2016). Seasonal differences in nitrogen and phosphorus uptake (by phytoplankton, for example) and loading (for example, from fertilizers and other land-use practices) would need to be better defined for the watershed to improve load calculations and establish a representative baseline for future remediation and implementation of green infrastructure and best management practices.

Results from the 12-month depth-profile survey and continuous water-quality monitoring site indicate that, with the exception of the shallow southwestern part of the pond (site 1), the established water-quality monitoring gage on the Maidstone Club golf cart bridge (Hook Pond site 10) would serve as a representative site for the continuous monitoring of physicochemical constituents at Hook Pond. Depending on the objectives of continuous monitoring (for example, monitoring eutrophication as opposed to monitoring for algal or cyanobacterial blooms, or focusing on localized data as opposed to overall pond variability), however, the significant percentage differences between the centers of the upper and lower portions of Hook Pond (sites 3 and 10) on a given day for most constituents ranged from less than 1.0 percent (water temperature) to about 120 percent (chlorophyll $a$ ), with a median percent difference of 13 percent. In the case of monitoring for algal or cyanobacterial blooms, differences in the chlorophyll $a$ measurements between the upper and lower parts of the pond may warrant monitoring at both Hook Pond site 10 and site 3 using a water-quality buoy or platform. Hook Pond site 10 provides easier access for maintenance, is less susceptible to storms, and may better capture storm-related contributions from Hook Pond Dreen, such as the road salt pulse observed in March 2018.

The $\mathrm{pH}$ values in $2017-18$ were similar to those recorded in depth profiles in 2001-8, with higher median values throughout Hook Pond in summer months and a maximum $\mathrm{pH}$ of 9.98 at site 1 (appendix tables 2.2 and 2.3). Although a pH greater than 8 in freshwater systems in summer months can be the result of high phytoplankton activity (Dubinsky and Rotem, 1974) and typically corresponds with elevated chlorophyll $a$ concentrations during the summer months (for example, Mill Pond typically experiences green algae blooms and exhibits $\mathrm{pH}$ greater than 9 during summer months [Water Mill, N.Y.; USGS station 01304738]), there was little correlation between pH and chlorophyll $a$ in Hook Pond over 2017-18 (appendix fig. 2.2). This finding suggests that the increases in $\mathrm{pH}$ may be the result of additional factors, such as land use. 
Consistent with historical USGS data and data presented in the Water Quality Improvement Project (Lombardo Associates, Inc., 2015), seasonally elevated chlorophyll $a$ concentrations (fluorescence) were greater than $20 \mu \mathrm{g} / \mathrm{L}$ (appendix tables 2.2 and 2.3), year-round concentrations of total phosphorus were greater than $0.024 \mathrm{mg} / \mathrm{L}$ as phosphorus (tables 3 and 4), and light penetration (per Secchi depths) throughout Hook Pond continued to be limited; all of which contribute to the eutrophic state of Hook Pond (Carlson, 1977) and the resulting low predawn dissolved oxygen concentrations. Water clarity is affected by suspended sediment and organic matter concentrations, algal biomass, bioturbation, and wind-driven upwelling, all of which can vary greatly throughout the day depending on weather, season, and nutrient availability. Because of the shallow depths (at most profile locations, depths to bottom were $<5 \mathrm{ft}$ ), diurnal changes in water temperature likely reach the bottom of the pond and can influence microbial processes in the surficial bed sediment layer, particularly with respect to the nitrogen cycle and releasing inorganic nitrogen and phosphorus into the water column (Burns and others, 2009; Hupfer and Lewandowski, 2008).

Depths to bottom values throughout Hook Pond (averaged per site for the nine sites without accounting for elevation recorded at site 10) were similar to those collected in 1981 and 1997 (Lombardo Associates, Inc., 2015). However, to evaluate the extent to which Hook Pond may be accumulating sediment and organic matter through time, depth data need to be relative to a known datum. For this study, depths were collected during each trip (with corresponding latitude and longitude, NAD 83, 1-second accuracy) and can be correlated to elevations recorded by the continuous monitor at site 10 on the respective dates and times (median depths and elevations are shown in table 1). These lakebed elevations can be used to derive a bathymetric map of the bottom through time for comparison to future surveys using the same datum (provided the pond level is also determined at the time in relation to a known elevation point, such as the spillway structure). Although direct comparisons of pond depth cannot be made for the three sets of measurements collected over the past 35 years, routine (for example, decadal) lakebed elevation surveys would help inform conditions as the climate changes, which is predicted to result in elevated sea level and storm surge as outlined in the (New York State) Community Risk and Resiliency Act (NYSDEC, 2014). Further assessment of shoreline loss resulting from sediment fill could be achieved with the use of unmanned aerial systems (drones) to collect aerial imagery on a routine basis and correlate the imagery with real-time watersurface elevation data referenced to a known datum.

Discrete samples of inorganic and organic forms of carbon from Hook Pond and Hook Pond Dreen, along with additional data on discharge under different streamflow conditions, would further complement an enhanced study of the Hook Pond watershed. These data could be coupled with continuous monitoring of $\mathrm{pH}$, dissolved oxygen, dissolved organic matter fluorescence, and total algae (fluorometric chlorophyll $a$ and phycocyanin), along with continuous monitoring of nitrate (by optical sensor) and phosphate (by reaction analyzer), at Hook Pond sites 3 (by buoy) or 10 (by retrofit of existing sensor pipe) to inform loading and cycling (both biologic and anthropogenic) of nutrients and to alert managers of potential algal and cyanobacterial blooms in Hook Pond.

\section{Microbial Source Tracking}

Samples were collected and analyzed for enterococci for comparison with bathing beach regulatory standards, E. coli for correlation with $\mathrm{F}^{+}$-specific coliphage presence/absence results, and fecal coliform for comparison with shellfishing standards. Although swimming in Hook Pond or Hook Pond Dreen does not appear to be common, fishing at the south end of Hook Pond and from the Dunemere Lane bridge was observed during sampling trips. The elevated concentrations of enterococci and E. coli measured along Hook Pond Dreen and in Hook Pond following a spring storm event, with sources in Hook Pond identified through MST analyses to be human and dog, present a potential public safety concern should primary contact or fishing occur shortly after a rain event.

Bacterial concentration, coliphage, and MST data from spring and summer samples indicate wildlife influence, while snowmelt concentrations of bacteria correlate with human and canine sources at Fithian Lane. The highest relative contributions of dog waste along Hook Pond Dreen consistently occur at Davids Lane south (Bacteroides; BacCan), and for a given event the relative contribution is 50 to 100 times greater than at Fithian Lane (table 6). This, along with the detections of human (HF183) markers in the spring storm samples, may be related to the walking path along Hook Pond Dreen that provides access to the water between Huntting Lane and Davids Lane. The single detection of HF183 at Fithian Lane in the summer nonstorm sample may point to a failing OWDS upstream or discharge within the storm sewers. Ruminant (Rum2Bac; for example, deer) and waterfowl (GFD) MST markers were also only detected in Davids Lane samples, with concentrations higher in the summer nonstorm sample. These data agree with the high number of resident birds observed at this location, which is immediately downstream from a local viewing and feeding area that likely also attracts deer and other wildlife. The relative distribution of MST markers is mostly consistent with the findings of shoreline and tributary samples at Georgica Pond in 2017 (Gobler and others, 2018), where dog and waterfowl waste were detected most frequently.

Seasonality and wet weather appear to be the greatest factors affecting the presence of $\mathrm{F}^{+}$-specific coliphages, with colder water temperatures, wet-weather (melting snow and rain) runoff, or both contributing to positive detections and marker grouping (table 6). Viruses such as coliphages have been observed to be more resilient to freezing than bacteria (Pinon and Vialette, 2018), and, accordingly, samples collected along Hook Pond during snowmelt may have remained virulent until hosts were available. While most detections were positive for the presence of coliphages with markers in group 
I (other animals, nonhuman), a sample from Fithian Lane was positive for a human marker (group III), suggesting that water entering Hook Pond Dreen from the storm sewer may have septic influences from either groundwater or direct runoff from failing OWDSs. Markers of $\mathrm{F}^{+}$-specific coliphages are thought to indicate sources from wastewater contamination rather than direct fecal sources (Havelaar and others, 1990); therefore, the human markers identified at Fithian Lane in the winter of 2018 (table 6) may be the result of septic influence on either the storm sewers discharging to Hook Pond Dreen at Fithian Lane or compromised OWDSs upstream of Fithian Lane.

There were no detections of fecal indicator bacteria or MST markers in the groundwater samples, which indicates limited mobility of pathogens introduced to the water table through OWDSs, despite clear influences of septic contamination in the shallow groundwater, as evidenced by the isotope ratio results in surface-water samples collected concurrently with the MST samples (tables 3-6). Results for the weekly samples collected by the Concerned Citizens of Montauk from Davids Lane (north side of road at the duck pond) off Hook Pond Dreen indicate high enterococci concentrations throughout the year (regularly >24,000 MPN/100 mL; Concerned Citizens of Montauk, 2020). Additionally, a single synoptic sample collected at the south side of Davids Lane by Suffolk County Department of Health Services on July 31, 2018, revealed elevated concentrations of total and fecal coliforms (9,000 MPN/100 mL each; Jonathan Wanlass, Suffolk County Department of Health Services, written commun., 2018). Both examples of elevated enterococci concentrations are consistent with results from this study.

\section{A Baseline for Future Research}

Constituents typically associated with stormwater runoff-polycyclic aromatic hydrocarbons, nutrients, pathogens - were all detected in 2017-18 and previous (2001-8) storm samples collected at Hook Pond. Rates of settling, decay, and reactivity vary by constituent following introduction to the stream, which can make it difficult to determine how many of, and at what concentration, the 27 wastewaterindicator compounds detected at Fithian Lane during the summer storm were transported to Hook Pond (table 5). That said, stormwater models, such as the USGS Stochastic Empirical Loading and Dilution Model (Granato, 2013) and the U.S. Department of Agriculture Soil and Water Assessment Tool (Arnold and others, 2012), are available that include factors, such as dilution and water-quality components, that can help answer these questions when coupled with discharge measurements and water-quality data. Tools that can help determine potential toxicity of chemical mixtures on the basis of the presence and concentrations of contaminants are also available from the USGS (De Cicco and others, 2019) and the EPA (2019b). If more information about stormwater transport times is desired, future studies could use automated composite samplers to capture samples of water throughout the storm and changes in stormflow and compare the sample results to established discharge data. Additionally, once a correlation has been developed on a seasonal or event basis, continuous specific conductance, groundwater elevation, and weather data could be used to estimate loading and groundwater contributions.

Currently (2020), the USGS is working in cooperation with the New York State Department of Environmental Conservation under the Long Island Nitrogen Action Plan to better delineate groundwater recharge areas throughout Long Island and compute travel times to better define outflows to surface waters (USGS, 2017a). The maps expected to result from this effort would provide better resolution of boundaries and the movement of groundwater within the Hook Pond watershed and, when used in conjunction with nutrient data from this study, could be used to estimate loading to the pond as is being completed for the Peconic Estuary (USGS, 2017b). A decision support tool for predicting changes in groundwater nutrient concentrations, such as the Cape Cod Commission WatershedMVP tool (Cape Cod Commission [n.d.]), which uses USGS groundwater flow and particle tracking models (Walter and Whealan, 2005) as the backbone, could also be developed to support environmental planning efforts. Perceived reductions in nutrients based on improvements to wastewater infrastructure, stormwater conveyance, fertilizer practices, and other management practices implemented by the Village of East Hampton to control nutrient inputs to groundwater could be calculated.

Recent case studies have shown effective use of green infrastructure (such as bioswales; Xiao and others, 2017) and other best management practices to reduce nutrient loading and stormwater runoff, though overall improvements to the ecological health of eutrophic lakes have proven slower to achieve (Steinman and others, 2018). In addition to addressing stormwater runoff (with examples provided in the Water Quality Improvement Project [Lombardo Associates, Inc., 2015]), reducing loading of both dissolved nutrients and organic matter, such as leaves (Selbig, 2016), has been shown to reduce phosphorus loading and improve surface-water and groundwater quality in similar geologic settings, such as Wisconsin and Cape Cod, and a similar response may be expected if grass clippings were reduced that may inadvertently make their way into Hook Pond following mowing of adjacent lawns and the golf course. Therefore, as changes to stormwater and septic management practices and wildlife control are implemented throughout the Village of East Hampton and Town of East Hampton, focused studies to track short-term and long-term water-quality monitoring plans could be initiated to monitor the relative changes in nutrient and bacteria concentrations to Hook Pond Dreen and groundwater conditions. However, given that groundwater moves on average $1 \mathrm{ft}$ per day in the shallow aquifer of Long Island's south shore (Franke and Cohen, 1972), reductions in current loads of nutrients from groundwater seepage would likely take years or decades before significant changes to Hook Pond water quality were observed. 
Data from continuous monitoring of water-surface elevations collected during this study are one component required to estimate loading of nutrients to Hook Pond, along with local weather data from the East Hampton Airport (KHTO) or from the Maidstone Club weather station (deployed seasonally; these data may be used, assuming measurements are frequent and quality assurance measures are in place) and USGS groundwater elevation data from the USGS National Water Information System database (https://waterdata.usgs.gov/nwis/ $\mathrm{gw}$ ). The narrow water-surface elevation range (relative to Georgica Pond) controlled by the ocean spillway makes Hook Pond analogous to other ponds along the south shore of Long Island that discharge over dams or weirs into the tidal estuary. As such, it would be expected that trends in nitrogen loading to groundwater serving as base flow would be affected by wastewater treatment practices (such as conversion of portions of the watershed with OWDSs to sewered) as is shown by Monti and Scorca (2003).

Continuous water-surface elevation data can also be used to better estimate the total volume of water flowing out of the pond according to the stage-discharge relationship developed for the Hook Pond Water Quality Improvement Project (Lombardo Associates, Inc., 2015), allowing managers to better regulate current pond level and future stormwater controls or best management practices. Baseline discharge measurements at four locations along Hook Pond Dreen provide insight into the relative ratio of groundwater discharge along the tributary. Although estimating a daily load from a single, dry-weather measurement can be informative, regular discharge measurements during dry and wet conditions throughout the year would be needed to develop a rating curve and could be supplemented with continuous groundwater elevation data from nearby tidally influenced shallow well S115135.1 These data could also inform a model for nutrient loading to Hook Pond via Hook Pond Dreen and track changes in overall groundwater elevation, as well as the implications of these changes for surrounding properties, as climate change is projected to raise sea level (NYSDEC, 2014). Furthermore, during periods of heavy rain, the total volume of water (from runoff [direct and at the stormwater outfall at Fithian Lane] and direct deposition) added to the Hook Pond Dreen watershed is unlikely to reach Hook Pond because Hook Pond Dreen will lose water to the adjacent aquifer when the elevation of the dreen is above the adjacent water table elevation.

\section{Summary}

The U.S. Geological Survey, in cooperation with the Village of East Hampton, New York, conducted a 1-year study from August 2017 to August 2018 to provide data necessary to improve understanding of the sources of nutrients and pathogens to Hook Pond watershed to allow for possible mitigation or reduction of loads. Chronic eutrophication and recent concern over harmful cyanobacteria in Hook Pond are the result of past and present land uses and a changing climate that have prompted the Village of East Hampton and local businesses to study and remediate factors contributing to the persistent loading of nutrients, organic contaminants, and pathogens. This assessment of Hook Pond, Hook Pond Dreen, and shallow groundwater provides the most comprehensive set of waterquality data to date. Interpretations presented in this study and the data on which they are based can be used to support management decisions, inform and contribute to modeling, and serve as a baseline for future assessments.

Results from continuous monitoring of water temperature, specific conductance, and elevation at Hook Pond site 10 (Maidstone Club golf cart bridge), as well as ancillary weather and tidal data from nearby stations, were used to help explain seasonal and storm-related concentration variation of nitrogen, phosphorus, wastewater-indicator compounds, and pathogens. Data collected were also compared to existing historical data. Physicochemical constituents measured on a routine basis throughout the pond and along the tributary showed the spatial variability in water temperature, specific conductance, dissolved oxygen, $\mathrm{pH}$, turbidity, and chlorophyll $a$ and phycocyanin fluorescence. A lakebed survey was compiled based on the year-round sampling throughout the pond for future comparisons. Water-quality data from shallow groundwater at points around Hook Pond and adjacent to Hook Pond Dreen were interpreted and quantified to estimate relative contributions and species of nutrients, wastewater-indicator compounds, and MST markers to base flow. To supplement the continuous water-surface elevation data, a single set of discharge measurements was collected under normal (nonstorm) conditions to better understand the relative contributions and dilution of surface waters by contaminated groundwater.

The nutrient and physicochemical data from this study can be used in conjunction with current and future models and decision support tools to guide planned and ongoing restoration efforts, such as dredging to reduce sediment accumulation, opening a pathway to the ocean (which would change the salinity and flow dynamics of the pond and adjacent groundwater), and addressing growing concerns over cyanobacterial blooms, while serving as a baseline for measuring changes resulting from sea-level rise, climate change, and changes in nutrient loading. The microbial source tracking and indicator bacteria results can help direct efforts to reduce runoff and direct contributions of fecal contamination from dogs and waterfowl along Hook Pond Dreen. The results can also be used to assess the current state of wastewater infrastructure surrounding and contributing to Hook Pond Dreen, based on detection of human markers throughout the year and with both Bacteroides and coliphage methods. 


\section{References Cited}

Abbene, I.J., 2010, Shallow groundwater quality in the Village of Patchogue, Suffolk County, New York: U.S. Geological Survey Scientific Investigations Report 2010-5132, 19 p. [Also available at https://doi.org/10.3133/sir20105132.]

Arnold, J.G., Kiniry, J.R., Srinivasan, R., Williams, J.R., Haney, E.B., and Neitsch, S.L., 2012, Soil and Water Assessment Tool—Input/output documentation: Texas Water Resources Institute, TR-439, 654 p. [Also available at https://swat.tamu.edu/docs/.]

Burns, D.A., Boyer, E.W., Elliot, E.M., and Kendall, C., 2009 , Sources of transformations of nitrate from streams draining varying land uses-Evidence from dual isotope analysis: Journal of Environmental Quality, v. 38, no. 3, p. 1149-1159.

Bushon, R.N., Brady, A.M.G., Christensen, E.D., and Stelzer, E.A., 2017, Multi-year microbial source tracking study characterizing fecal contamination in an urban watershed: Water Environment Research, v. 89, no. 2, p. 127-143., April 16, 2020, at https://doi.org/10.2175/ 106143016 X14798353399412.

Cape Cod Commission, [n.d.], WatershedMVP: Cape Cod Commission web application, accessed March 4, 2020, at http://2014.watershedmvp.org/.

Carlson, R.E., 1977, A trophic state index for lakes: Limnology and Oceanography, v. 22, no. 2, p. 361-369.

Colman, J.A., LeBlanc, D.R., Böhlke, J.K., McCobb, T.D., Kroeger, K.D., Belaval, M., Cambareri, T.C., Pirolli, G.F., Brooks, T.W., Garren, M.E., Stover, T.B., and Keeley, A., 2018, Geochemical conditions and nitrogen transport in nearshore groundwater and the subterranean estuary at a Cape Cod embayment, East Falmouth, Massachusetts, 2013-14: U.S. Geological Survey Scientific Investigations Report 2018-5095, 69 p., March 4, 2020, at https://doi.org/ $10.3133 /$ sir20185095.

Concerned Citizens of Montauk, 2020, Concerned Citizens of Montauk - Water quality - Water testing results: Concerned Citizens of Montauk website, accessed March 4, 2020, at http://www.preservemontauk.org/.

Coplen, T.B., Qi, H., Révész, K., Casciotti, K., and Hannon, J.E., 2012, Determination of the $\delta^{15} \mathrm{~N}$ and $\delta^{18} \mathrm{O}$ of nitrate in water; RSIL lab code 2900 (version 1.1, September 2012): U.S. Geological Survey Techniques and Methods, book 10, chap. C17, 35 p., March 4, 2020, at https://doi.org/10.3133/ tm10C17.
De Cicco, L.A., Corsi, S.R., Villeneuve, D.L., Blackwell, B.R., and Ankley, G.T., 2019, Toxeval-Evaluation of measured concentration data using the toxcast high-throughput screening database or a user-defined set of concentration benchmarks [ver. 1.0.0]: U.S. Geological Survey software release, accessed March 4, 2020, at https://doi.org/10.5066/ p906uq5i.

Dubinsky, Z., and Rotem, J., 1974, Relations between algal populations and the $\mathrm{pH}$ of their media: Oecologia, v. 16, p. 53-60, accessed March 4, 2020, at https://doi.org/ 10.1007/BF00345087.

Duncan, J.M., Welty, C., Kemper, J.T., Groffman, P.M., and Band, L.E., 2017, Dynamics of nitrate concentrationdischarge patterns in an urban watershed: Water Resources Research, v. 53, no. 8, p. 7349-7365, March 4, 2020, at https://doi.org/10.1002/2017WR020500.

Fairbairn, D.J., Karpuzcu, M.E., Arnold, W.A., Barber, B.L., Kaufenberg, E.F., Koskinen, W.C., Novak, P.J., Rice, P.J., and Swackhamer, D.L., 2016, Sources and transport of contaminants of emerging concern-A two-year study of occurrence and spatiotemporal variation in a mixed land use watershed: Science of the Total Environment, v. 551-552, p. 605-613, March 4, 2020, at https://doi.org/10.1016/ j.scitotenv.2016.02.056.

Feinson, L.S., Gibs, J., Imbrigiotta, T.E., and Garrett, J.D., 2016, Effects of land use and sample location on nitratestream flow hysteresis descriptors during storm events: Journal of the American Water Resources Association, v. 52, no. 6, 16 p., accessed March 4, 2020, at https://doi.org/ 10.1111/1752-1688.12477.

Fisher, I.J., Phillips, P.J., Colella, K.M., Fisher, S.C., Tagliaferri, T.N., Foreman, W.T., and Furlong, E.T., 2016, The impact of onsite wastewater disposal systems on groundwater in areas inundated by Hurricane Sandy in New York and New Jersey: Marine Pollution Bulletin, v. 107 , no. 2, p. 509-517.

Fisher, S.C., Reilly, T.J., Jones, D.K., Benzel, W.M., Griffin, D.W., Loftin, K.A., Iwanowicz, L.R., and Cohl, J.A., 2015, Standard operating procedure for collection of soil and sediment samples for the Sediment-bound Contaminant Resiliency and Response (SCoRR) strategy pilot study: U.S. Geological Survey Open-File Report 2015-1188B, 37 p. [Also available at https://doi.org/10.3133/ofr20151188B.]

Fishman, M.J., ed., 1993, Methods of analysis by the U.S. Geological Survey National Water Quality LaboratoryDetermination of inorganic and organic constituents in water and fluvial sediments, U.S. Geological Survey Open-File Report v. 93-125, 217 p., March 4, 2020, at https://doi.org/10.3133/ofr93125. 
Franke, O.L., and Cohen, P., 1972, Regional rates of groundwater movement on Long Island, New York-Geological Survey Research: U.S. Geological Survey Professional Paper 800-C, p. C271-C277. [Also available at https://doi.org/10.3133/pp800C.]

Gobler, C.J., Burkholder, J.M., Davis, T.W., Harke, M.J., Johengen, T., Stow, C.A., and Van de Waal, D.B., 2016, The dual role of nitrogen supply in controlling the growth and toxicity of cyanobacterial blooms: Harmful Algae, v. 54, p. 87-97, March 4, 2020, at https://doi.org/10.1016/ j.hal.2016.01.010.

Gobler, C.J., Jankowiak, J., and Hattenrath-Lehmann, T., 2018, Source tracking of fecal bacteria in Georgica Pond: Stony Brook University School of Marine and Atmospheric Sciences, Report to Friends of Georgica Pond, 14 p.

Graham, J.L., Jones, J.R., Jones, S.B., Downing, J.A., and Clevenger, T.E., 2004, Environmental factors influencing microcystin distribution and concentration in the Midwestern United States: Water Research, v. 38, no. 20, p. 4395-4404, accessed March 4, 2020, at https://doi.org/ 10.1016/j.watres.2004.08.004.

Granato, G.E., 2013, Stochastic empirical loading and dilution model (SELDM) version 1.0.0: U.S. Geological Survey Techniques and Methods, book 4, chap. C3, 112 p. [Also available on CD-ROM and at https://doi.org/10.3133/ tm4C3.]

Green, H.C., Dick, L.K., Gilpin, B., Samadpour, M., and Field, K.G., 2012, Genetic markers for rapid PCR-based identification of gull, Canada goose, duck, and chicken fecal contamination in water: Applied and Environmental Microbiology, v. 78, no. 2, p. 503-510. https://doi.org/ 10.1128/AEM.05734-11.

Griffin, D.W., Stokes, R., Rose, J.B., and Paul, J.H., III, 2000, Bacterial indicator occurrence and the use of an F+-specific RNA coliphage assay to identify fecal sources in Homosassa Springs, Florida: Microbial Ecology, v. 39, p. 56-64, accessed March 4, 2020, at https://doi.org/ $10.1007 / \mathrm{s} 002489900193$.

Hannon, J.E., and Böhlke, J.K., 2008, Determination of the $\delta(15 \mathrm{~N} / 14 \mathrm{~N})$ of ammonium $\left(\mathrm{NH}_{4}^{+}\right)$in water: RSIL lab code 2898: U.S. Geological Survey Techniques and Methods book 10, chap. C15, $30 \mathrm{p}$.

Hasler, A.D., 1947, Eutrophication of lakes by domestic drainage: Ecology, v. 28, no. 4, p. 383-395, accessed March 4, 2020, at https://doi.org/10.2307/1931228.
Havelaar, A.H., Pot-Hogeboom, W.M., Furuse, K., Pot, R., and Hormann, M.P., 1990, F-specific RNA bacteriophages and sensitive host strains in faeces and wastewater of human and animal origin: Journal of Applied Bacteriology, v. 69, no. 1, p. 30-37, accessed March 4, 2020, at https://doi.org/ 10.1111/j.1365-2672.1990.tb02908.x.

Helsel, D.R., and Hirsch, R.M., 2002, Statistical Methods in Water Resources: U.S. Geological Survey Techniques of Water-Resource Investigations, book 4, chap. A3, 522 p., March 4, 2020, at https://doi.org/10.3133/twri04A3.

Hupfer, M., and Lewandowski, J., 2008, Oxygen controls the phosphorus release from lake sediments - A longlasting paradigm in limnology: International Review of Hydrobiology, v. 93, no. 4-5, p. 415-432, accessed March 4, 2020, at https://doi.org/10.1002/iroh.200711054.

Iowa State University, 2019, New York ASOS, [HTO] East Hampton station weather data, August 2017 to August 2018: Iowa State University Iowa Environmental Mesonet network, accessed February 6, 2019, at http://mesonet.agron.iastate.edu/request/download.phtml.

Jang, J., Hur, H.G., Sadowsky, M.J., Byappanahalli, M.N., Yan, T., and Ishii, S., 2017, Environmental Escherichia coli-Ecology and public health implications-a review: Journal of Applied Microbiology, v. 123, no. 3, p. 570-581. https://doi.org/10.1111/jam.13468.

Johnson, R.C., Mercier, T.J., and Brownfield, M.E., 2014, Spatial and stratigraphic distribution of water in oil shale of the Green River Formation using Fischer Assay, Piceance Basin, northwestern Colorado: U.S. Geological Survey Open-File Report 2014-1059, 57 p., accessed April 14, 2019, at https://doi.org/10.3133/ofr20141059.

Kaiserli, A., Voutsa, D., and Samara, C., 2002, Phosphorus fractionation in lake sediments - Lakes Volvi and Koronia, N. Greece: Chemosphere, v. 46, no. 8, p. 1147-1155, accessed March 4, 2020, at https://doi.org/10.1016/S00456535(01)00242-9.

Kendall, C., and Caldwell, E.A., eds., 1998, Isotope tracers in catchment hydrology: Amsterdam, Elsevier Science, 839 p.

Kendall, C., Doctor, D.H., and Young, M.B., 2014, Environmental isotope applications in hydrologic studies in Holland, H.D., and Turekian, K.K., eds., 2014, Treatise on geochemistry ( $2 \mathrm{~d}$ ed.): Amsterdam, Elsevier Ltd., v. 7, p. 273-327, accessed March 4, 2020, at https://doi.org/ 10.1016/B978-0-08-095975-7.00510-6. 
Kildare, B.J., Leutenegger, C.M., McSwain, B.S., Bambic, D.G., Rajal, V.B., and Wuertz, S., 2007, 16S rRNA-based assays for quantitative detection of universal, human-, cow-, and dog-specific fecal Bacteroidales-A Bayesian approach: Water Research, v. 41, no. 16, p. 3701-3715, accessed March 4, 2020, at https://doi.org/10.1016/ j.watres.2007.06.037.

Lombardo Associates, Inc., 2015, Hook Pond Water Quality Improvement Project: Newton, Mass., Lombardo Associates, Inc., 291 p.

Marvin, C., Coakley, J., Mayer, T., Brown, M., and Thiessen, L., 2001, Application of faecal sterol ratios in sediments and effluents as source tracers: Water Quality Research Journal, v. 36, no. 4, p. 781-792, accessed March 4, 2020, at https://doi.org/10.2166/wqri.2001.041.

Mieszkin, S., Yala, J.F., Joubrel, R., and Gourmelon, M., 2010, Phylogenetic analysis of Bacteroidales 16S rRNA gene sequences from human and animal effluents and assessment of ruminant faecal pollution by real-time PCR: Journal of Applied Microbiology, v. 108, no. 3, p. 974-984, accessed March 4, 2020, at https://doi.org/10.1111/j.13652672.2009.04499.x.

Monti, J., Jr., and Scorca, M.P., 2003, Trends in nitrogen concentration and nitrogen loads entering the South Shore Estuary Reserve from streams and ground-water discharge in Nassau and Suffolk counties, Long Island, New York, 1952-97: U.S. Geological Survey Water-Resources Investigations Report 2002-4255, 36 p., accessed March 4, 2020, at https://pubs.er.usgs.gov/publication/wri024255.

National Oceanic and Atmospheric Administration [NOAA] [2019], Vertcon - North American Vertical Datum Conversion: National Oceanic and Atmospheric Administration website, accessed March 4, 2020, at https://www.ngs.noaa.gov/TOOLS/Vertcon/vertcon.html.

New York State Department of Environmental Conservation [NYSDEC] [2014], Community risk and resiliency act (CRRA) - Mainstreaming consideration of climate change: New York State Department of Environmental Conservation web page, accessed March 4, 2020, at https://www.dec.ny.gov/energy/102559.html.

New York State Department of Environmental Conservation [NYSDEC], 2016a, List of impaired waters 303(d): New York State website, accessed January 28, 2019, at https://www.dec.ny.gov/outdoor/24168.html.

New York State Department of Environmental Conservation [NYSDEC], 2016b, Priority waterbodies list: New York State website, accessed January 28, 2019, at https://www.dec.ny.gov/docs/water_pdf/wiatllissbao.pdf.
New York State Department of Environmental Conservation [NYSDEC], 2019, Hook Pond: New York State website, accessed January 28, 2019, at https://www.dec.ny.gov/ outdoor/24168.html.

Newell, S.E., Davis, T.W., Johengen, T.H., Gossiaux, D., Burtner, A., Palladino, D., and McCarthy, J., 2019, Reduced forms of nitrogen are a driver for non-nitrogen-fixing harmful cyanobacterial blooms and toxicity in Lake Erie: Harmful Algae, v. 81, p. 86-93, accessed March 4, 2020, year, at https://doi.org/10.1016/j.hal.2018.11.003.

O’Neil, J.M., Davis, T.W., Burford, M.A., and Gobler, C.J., 2012, The rise of harmful cyanobacteria blooms-The potential roles of eutrophication and climate change: Harmful Algae, v. 14, p. 313-334, accessed March 4, 2020, at https://doi.org/10.1016/j.hal.2011.10.027.

Patton, C.J., and Kryskalla, J.R., 2011, Colorimetric determination of nitrate plus nitrite in water by enzymatic reduction, automated discrete analyzer methods: U.S. Geological Survey Techniques and Methods, book 5, chap. B8, 34 p.

Patton, C.J., and Truitt, E.P., 2000, Methods of analysis by the U.S. Geological Survey National Water Quality Laboratory; determination of ammonium plus organic nitrogen by a Kjeldahl digestion method and an automated photometric finish that includes digest cleanup by gas diffusion: U.S. Geological Survey Open-File Report 2000-170, 31 p., accessed March 4, 2020, at https://doi.org/10.3133/ ofr00170.

Pinon, A., and Vialette, M., 2018, Survival of viruses in water: Intervirology, v. 61, p. 214-222, accessed March 4, 2020, at https://doi.org/10.1159/000484899.

Selbig, W.R., 2016, Evaluation of leaf removal as a means to reduce nutrient concentrations and loads in urban stormwater: Science of the Total Environment, v. 571, p. 124-133, accessed March 4, 2020, at https://doi.org/10.1016/ j.scitotenv.2016.07.003.

Seurinck, S., Defoirdt, T., Verstraete, W., and Siciliano, S.D., 2005, Detection and quantification of the human-specific HF183 Bacteroides 16S rRNA genetic marker with realtime PCR for assessment of human faecal pollution in freshwater: Environmental Microbiology, v. 7, no. 2, p. 249-259, accessed March 4, 2020, at https://doi.org/10.1111/j.14622920.2004.00702.x.

Steinman, A.D., Hassett, M., and Oudsema, M., 2018, Effectiveness of best management practices to reduce phosphorus loading to a highly eutrophic lake: International Journal of Environmental Research and Public Health, v. 15, no. 10, article 2111, 23 p., accessed March 4, 2020, at https://doi.org/10.3390/ijerph15102111. 
Stoliker, D.L., Repert, D.A., Smith, R.L., Song, B., LeBlanc, D.R., McCobb, T.D., Conaway, C.H., Hyun, S.P., Koh, D.-C., Moon, H.S., and Kent, D.B., 2016, Hydrologic controls on nitrogen cycling processes and functional gene abundance in sediments of a groundwater flow-through lake: Environmental Science \& Technology, v. 50, no. 7, p. 3649-3657, accessed March 4, 2020, at https://doi.org/ 10.1021/acs.est.5b06155.

Søndergaard, M., Jensen, J.P., and Jeppesen, E., 2003, Role of sediment and internal loading of phosphorus in shallow lakes: Hydrobiologia, v. 506-509, p. 135-145, accessed March 4, 2020, at https://doi.org/10.1023/ B:HYDR.0000008611.12704.dd.

The Southampton Press, 2009, Mill Pond problems may have been caused by effort to prevent algae: The Southampton [New York] Press, March 4, 2009, accessed March 4, 2020, at https://www.27east.com/southampton-press/mill-pondproblems-may-have-been-caused-by-effort-to-preventalgae-1500162/.

Turnipseed, D.P., and Sauer, V.B., 2010, Discharge measurements at gaging stations: U.S. Geological Survey Techniques and Methods, book 3, chap. A8, 87 p. [Also available at $\mathrm{https}: / /$ pubs.usgs.gov/tm/tm3-a8/.]

U.S. Environmental Protection Agency [EPA], 2012, Recreational water quality criteria: U.S. Environmental Protection Agency unbound publication 820F12058, 69 p., accessed March 4, 2020, at https://www.epa.gov/wqc/2012recreational-water-quality-criteria-documents.

U.S. Environmental Protection Agency [EPA] [2019a], Recreational water quality criteria and methods: U.S. Environmental Protection Agency web page, accessed March 4, 2020, at https://www.epa.gov/wqc/recreationalwater-quality-criteria-and-methods\#coliphage.

U.S. Environmental Protection Agency [EPA] [2019b], Toxicity forecasting: U.S. Environmental Protection Agency website, accessed March 4, 2020, at https://www.epa.gov/ chemical-research/toxicity-forecasting.

U.S. Food and Drug Administration [FDA] [2017], Guide for the control of molluscan shellfish-2017 revision: U.S. Food and Drug Administration, 478 p., accessed June 2019, at https://www.fda.gov/media/117080/download.

U.S. Geological Survey [USGS], [variously dated], National field manual for the collection of water-quality data: U.S. Geological Survey Techniques and Methods, book 9, chaps A1-A10, accessed December 17, 2018, at https://water.usgs.gov/owq/FieldManual/.
U.S. Geological Survey [USGS], 2008, Field measurements [Wilde, F.D., ed.]: U.S. Geological Survey Techniques of Water-Resources Investigations, book 9; chap A6, [variously paged], accessed December 17, 2018, at https://doi.org/10.3133/twri09A6.

U.S. Geological Survey [USGS], 2017a, Comprehensive delineation of groundwater source areas and timesof-travel to long island streams and estuaries: U.S. Geological Survey project web page, accessed March 4, 2020, at https://www.sciencebase.gov/catalog/item/ 565 c5bbde $4 b 071 \mathrm{e} 7 \mathrm{ea} 542 \mathrm{e} 33$.

U.S. Geological Survey [USGS], 2017b, The use of solutetransport methods to estimate time-varying nitrogen loading rates to the Peconic Estuary resulting from wastewater and fertilizer inputs to groundwater in Suffolk County, New York (Peconic Solute Transport): U.S. Geological Survey project web page, accessed March 4, 2020, at https://www.sciencebase.gov/catalog/item/ 59ef66dae4b0220bbd98d386.

U.S. Geological Survey [USGS], 2020a, USGS water data for the Nation: U.S. Geological Survey National Water Information System database, accessed June 9, 2020, at https://doi.org/10.5066/F7P55KJN.

U.S. Geological Survey [USGS], 2020b, Water quality samples for the Nation, in USGS water data for the Nation: U.S. Geological Survey National Water Information System database, accessed September 30, 2018, at https://doi.org/ $10.5066 /$ F7P55KJN. [Site information directly accessible at https://nwis.waterdata.usgs.gov/usa/nwis/qwdata.]

Vatovec, C., Phillips, P., Van Wagoner, E., Scott, T.-M., and Furlong, E., 2016, Investigating dynamic sources of pharmaceuticals-Demographic and seasonal use are more important than down-the-drain disposal in wastewater effluent in a University City setting: Science of the Total Environment, v. 572, p. 906-914, accessed March 4, 2020, at https://doi.org/10.1016/j.scitotenv.2016.07.199.

Wagner, R.J., Boulger, R.W., Jr., Oblinger, C.J., and Smith, B.A., 2006, Guidelines and standard procedures for continuous water-quality monitors-Station operation, record computation, and data reporting: U.S. Geological Survey Techniques and Methods, book 1, chap. D3, 51 p., accessed April 10, 2006, at https://pubs.water.usgs.gov/tm1d3.

Walter, D.A., Rea, B.A., Stollenwerk, K.G., and Savoie, J.G., 1996, Geochemical and hydrologic controls on phosphorus transport in a sewage-contaminated sand and gravel aquifer near Ashumet Pond, Cape Cod, Massachusetts: U.S. Geological Survey Water Supply Paper 2463, 89 p. [Also available at https://pubs.er.usgs.gov/publication/wsp2463.] 
Walter, D.A., and Whealan, A.T., 2005, Simulated water sources and effects of pumping on surface and ground water, Sagamore and Monomoy flow lenses, Cape Cod, Massachusetts: U.S. Geological Survey Scientific Investigations Report 2004-5181, 85 p., accessed March 4, 2020, at https://doi.org/10.3133/sir20045181.

Wolf, S., Hewitt, J., Rivera-Aban, M., and Greening, G.E., 2008 , Detection and characterization of $\mathrm{F}^{+}$RNA bacteriophages in water and shellfish-Application of a multiplex real-time reverse transcription PCR: Journal of Virological Methods, v. 149, no. 1, p. 123-128, accessed March 4, 2020, at https://doi.org/10.1016/j.jviromet.2007.12.012.

Xiao, Q., McPherson, E.G., Zhang, Q., Ge, X., and Dahlgren, R., 2017, Performance of two bioswales on urban runoff management: Infrastructures, v. 2, no. 12, 14 p., accessed March 4, 2020, at https://doi.org/10.3390/ infrastructures 2040012 .

Zaugg, S.D., Smith, S.G., Schroeder, M.P., Barber, L.B., and Burkhardt, M.R., 2002, Methods of analysis by the U.S. Geological Survey National Water Quality LaboratoryDetermination of wastewater compounds by polystyrenedivinylbenzene solid-phase extraction and capillary-column gas chromatography/mass spectrometry: U.S. Geological Survey Water-Resources Investigations Report 01-4186, 37 p. [Also available at https://pubs.usgs.gov/wri/ wri014186/.] 


\section{Appendix 1. Expanded Description of Analytical Methods}

The list of analytes for each U.S. Geological Survey (USGS) National Water Quality Laboratory method used in this study and their respective reporting units, parameter codes, Chemical Abstract Service Registry Numbers, ${ }^{1}$ and reporting limits are shown in table 1.1.

The methods used for $\mathrm{F}^{+}$-specific coliphage analysis are referenced in Griffin and others (2000); however, these samples were processed at the USGS Environmental and Public Health Microbiology Laboratory in St. Petersburg, Florida, according to the following procedure.

Prior to processing samples, a volume (15 milliliters $[\mathrm{mL}]$ per sample) of trypticase soy broth was spiked with approximately $1 \mathrm{~mL}$ of Escherichia coli $\mathrm{F}_{\text {amp }}$ (American Type Culture Collection number 700891) previously cultured in the soy broth and stored by refrigeration. This newly spiked culture was then incubated at 36.5 degrees Celsius $\left({ }^{\circ} \mathrm{C}\right)$ for approximately 3 hours until the culture appeared cloudy.

For direct, single-layer overlays, trypticase soy agar tubes (soy broth with 1.2 percent agar, $7 \mathrm{~mL}$ in a $15 \mathrm{~mL}$ tube) were melted in a boiling water bath and then cooled in a water bath at $50{ }^{\circ} \mathrm{C}$. For inoculation of the overlays, 70 microliters $(\mu \mathrm{L})$ of 10-percent 2,3,5-triphenyl tetrazolium chloride, $10 \mu \mathrm{L}$ of an ampicillin and streptomycin suspension $(0.15$ gram [g] of ampicillin sodium salt and $0.15 \mathrm{~g}$ of streptomycin sulfate in $100 \mathrm{~mL}$ of deionized water), $1 \mathrm{~mL}$ of $E$. coli $\mathrm{F}_{\text {amp }}$ culture, and $2 \mathrm{~mL}$ of sample were added to the trypticase soy agar overlay tube, mixed by hand rotation, and poured into a petri dish (this was done in triplicate for each sample). Once solidified in a laminar flow hood, these overlays were incubated at $36.5^{\circ} \mathrm{C}$ overnight and counted the following day. Negative $(5 \mu \mathrm{L}$ of deionized water) and positive controls ( $5 \mu \mathrm{L}$ of bacteriophage MS2 culture spot check from a frozen stock) were prepared with each sample set. These spot checks were inoculated onto a solidified overlay plate that was inoculated with $2.5 \mathrm{~mL}$ of deionized water instead of sample.

For the enrichment assays, the remaining volume of the 1 liter of each sample was spiked with $30 \mathrm{~g}$ of trypticase soy broth and $10 \mathrm{~mL}$ of $E$. coli $\mathrm{F}_{\text {amp }}$ and incubated overnight at $36.5^{\circ} \mathrm{C}$. The following day a $5-\mu \mathrm{L}$ aliquot of these samples was spot checked onto a dried overlay plate that was inoculated with $2.5 \mathrm{~mL}$ of deionized water instead of sample. For any sample that resulted in a plaqued spot check, $50 \mathrm{~mL}$ of sample was transferred to a sterile 50-mL tube and frozen at $-20{ }^{\circ} \mathrm{C}$ until ribonucleic acid (RNA) was extracted.

For the spot-checked positive samples, the frozen $50-\mathrm{mL}$ tube was thawed, and $12 \mathrm{~mL}$ was transferred to a $15 \mathrm{~mL}$ tube and centrifuged at 5,900 times Earth's gravitational force for 30 minutes. The supernatant was then transferred to an Amicon Ultra-15 centrifugal filtration unit (with pore size to limit 50,000-dalton molecules) and centrifuged at 5,900

1This report contains CAS Registry Numbers, which is a registered trademark of the American Chemical Society. CAS recommends the verification of the CASRNs through CAS Client Services. times Earth's gravitational force for 20 minutes in a Beckman Coulter Avanti J-E by using a fixed-angle rotor. The resulting retentate (about $200 \mu \mathrm{L}$ ) was then utilized for RNA extraction by using Qiagen's QIAamp Viral RNA Mini Kit. RNA was extracted by using $50 \mu \mathrm{L}$ of Qiagen's AVE buffer into $5 \mu \mathrm{L}$ of Qiagen's RNAse Inhibitor (4 units of product). Extracted RNA was stored at $-20^{\circ} \mathrm{C}$ until evaluated with the reverse transcriptase-polymerase chain reaction.

Presence or absence verification with the reverse trascriptase polymerase chain reaction was conducted in duplicate for each $\mathrm{F}^{+}$-specific coliphage group (I, II, III, and IV) using $2 \mu \mathrm{L}$ of sample extract per reaction. Primer and probe sequences were prepared per previously published methodology (Wolf and others, 2008). Master mix reaction volumes were $20 \mu \mathrm{L}$. PCR reactions were run in an Applied Biosystems StepOnePlus thermocycler using Applied Biosystems Taqman Fast Virus 1-Step Master Mix and Exogenous Internal Positive Control (IPC) reagents. The IPC reagent reactions were conducted with sample spike without target primers and probes to account for any observable assay inhibition. Target reactions were conducted in multiple-gene-targeted (multiplex) reactions with one viral group probe labeled with FAM and the other with VIC. Target, negative, and IPC controls were used. The $20 \mu \mathrm{L}$ of master mix per reaction for the IPC samples was made from $5 \mu \mathrm{L}$ of the Fast Virus mix, $2 \mu \mathrm{L}$ of $10 \times$ IPC reagent, $0.4 \mu \mathrm{L}$ of $50 \times$ IPC template, $10.6 \mu \mathrm{L}$ of PCR-grade water, and $2 \mu \mathrm{L}$ of sample template. The per-reaction master mix for the multiplex reactions was $5 \mu \mathrm{L}$ of Fast Virus mix, $9 \mu \mathrm{L}$ of water, $2 \mu \mathrm{L}$ of each 10 micrometers $(\mu \mathrm{m})$ primer and probe mix, and $2 \mu \mathrm{L}$ of template. Positive control reactions used this same master mix recipe with $2 \mu \mathrm{L}$ of dilute control template for each multiplex target. IPC master mix per reaction was $5 \mu \mathrm{L}$ of the Fast Virus mix, $2 \mu \mathrm{L}$ of $10 \times$ IPC, $0.4 \mu \mathrm{L}$ of $50 \times$ IPC template, $10.6 \mu \mathrm{L}$ of polymerase chain reactiongrade water, and $2 \mu \mathrm{L}$ of IPC block reagent or $2 \mu \mathrm{L}$ of polymerase chain reaction-grade water. Reactions were deemed positive if exponential amplification was noted in both of the duplicate reactions.

The microbial source tracking (MST) method was used for sample handling, and analyses were provided by the Ohio Water Microbiological Laboratory (OWML). Data qualityassurance procedures and qualifier codes are summarized as follows:

Water samples were filtered through a $0.4-\mu \mathrm{m}$ pore-size polycarbonate filter at the OWML the day after collection. The volume of filtered sample varied depending on the clarity of the water and ranged from 35 to $100 \mathrm{~mL}$. Filters were placed in vials containing $0.3 \mathrm{~g}$ of acid-washed glass beads, and the vials were preserved at $-70{ }^{\circ} \mathrm{C}$ until deoxyribonucleic acid (DNA) extraction and analysis by the quantitative polymerase chain reaction (qPCR). 
Table 1.1. Analytes for U.S. Geological Survey National Water Quality Laboratory schedules 2702, 2755, and 1433.

[Reporting limits for the wastewater-indicator method (LS1433) are in micrograms per liter. Parameter codes are used by the National Water Quality Laboratory to identify analytes. CASRN, Chemical Abstract Service Registry Number; LS, laboratory schedule; NA, not applicable.]

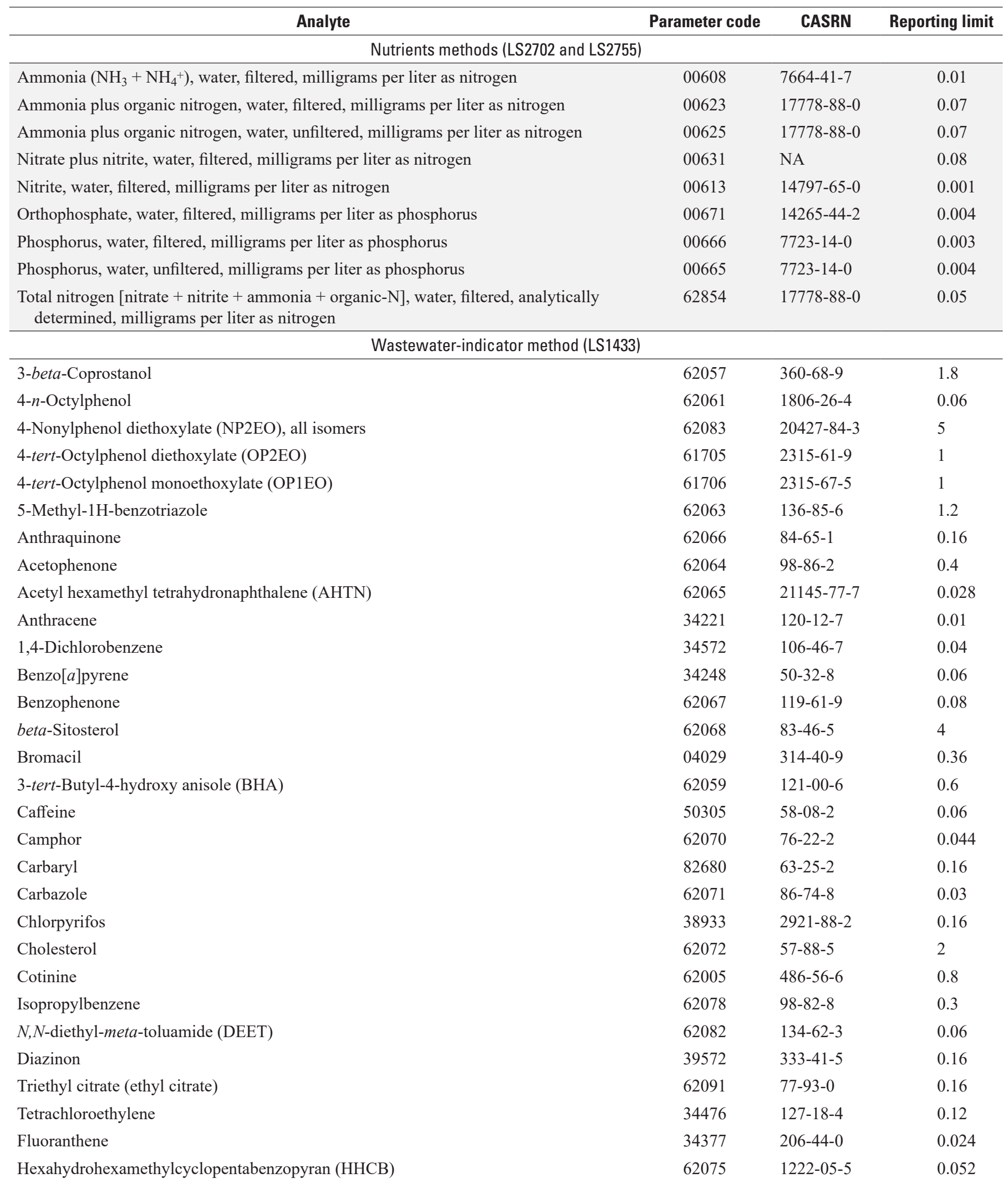


Table 1.1. Analytes for U.S. Geological Survey National Water Quality Laboratory schedules 2702, 2755, and 1433.—Continued

[Reporting limits for the wastewater-indicator method (LS1433) are in micrograms per liter. Parameter codes are used by the National Water Quality Laboratory to identify analytes. CASRN, Chemical Abstract Service Registry Number; LS, laboratory schedule; NA, not applicable.]

\begin{tabular}{|c|c|c|c|}
\hline & Parameter code & CASRN & Reporting limit \\
\hline \multicolumn{4}{|c|}{ Wastewater-indicator method (LS1433)—Continued } \\
\hline Indole & 62076 & $120-72-9$ & 0.08 \\
\hline Isoborneol & 62077 & $124-76-5$ & 0.08 \\
\hline Isophorone & 34409 & $78-59-1$ & 0.032 \\
\hline Isoquinoline & 62079 & $119-65-3$ & 0.8 \\
\hline$d$-Limonene & 62073 & $5989-27-5$ & 0.08 \\
\hline Menthol & 62080 & $89-78-1$ & 0.32 \\
\hline Metalaxyl & 50359 & $57837-19-1$ & 0.12 \\
\hline Metolachlor & 39415 & $51218-45-2$ & 0.028 \\
\hline Naphthalene & 34443 & $91-20-3$ & 0.04 \\
\hline 1-Methylnaphthalene & 62054 & $90-12-0$ & 0.022 \\
\hline 2,6-Dimethylnaphthalene & 62055 & $581-42-0$ & 0.06 \\
\hline 2-Methylnaphthalene & 62056 & $91-57-6$ & 0.036 \\
\hline$p$-Cresol & 62084 & $106-44-5$ & 0.08 \\
\hline 4-Cumylphenol & 62060 & $599-64-4$ & 0.06 \\
\hline para-Nonylphenol (total) (branched) & 62085 & $84852-15-3$ & 2 \\
\hline 4-tert-Octylphenol & 62062 & $140-66-9$ & 0.14 \\
\hline Phenanthrene & 34462 & $85-01-8$ & 0.016 \\
\hline Phenol & 34466 & $108-95-2$ & 0.16 \\
\hline Tributyl phosphate & 62089 & $126-73-8$ & 0.16 \\
\hline Triphenyl phosphate & 62092 & $115-86-6$ & 0.12 \\
\hline Tris(2-butoxyethyl)phosphate & 62093 & $78-51-3$ & 0.8 \\
\hline Tris(2-chloroethyl)phosphate & 62087 & $115-96-8$ & 0.1 \\
\hline Prometon & 04037 & $1610-18-0$ & 0.12 \\
\hline Pyrene & 34470 & $129-00-0$ & 0.042 \\
\hline Methyl salicylate & 62081 & 119-36-8 & 0.044 \\
\hline 3-Methyl-1 $(H)$-indole (skatole) & 62058 & $83-34-1$ & 0.036 \\
\hline beta-Stigmastanol & 62086 & $19466-47-8$ & 2.6 \\
\hline Tribromomethane & 34288 & $75-25-2$ & 0.1 \\
\hline Triclosan & 62090 & $3380-34-5$ & 0.2 \\
\hline Tris(dichloroisopropyl)phosphate & 62088 & $13674-87-8$ & 0.16 \\
\hline
\end{tabular}


DNA was extracted from the filters by use of the GeneRite DNA-EZ extraction kit according to manufacturer's instructions. Samples were analyzed for the following host-associated MST markers by qPCR. Assays for each marker are performed according to protocols based on the following references:

- canine-associated Bacteroides marker (BacCan, Kildare and others, 2007)

- waterfowl-associated Helicobacter marker (GFD, Green and others, 2012)

- human-associated Bacteroides marker (HF183, Seurinck and others, 2005)

- ruminant-associated Bacteroides marker (Rum2Bac, Mieszkin and others, 2009)

\section{Quality Control}

The following quality-control procedures were followed:

- In addition to field blanks collected on site by the USGS, several types of blank samples were created during the analytical process:

o filter blank - sterile, buffered water filtered at the same time as the samples at the OWML

o extraction blank - sterile vial containing only acidwashed beads was extracted along with extraction of the samples

o qPCR blanks (no template controls) —sterile, molecular-grade water used instead of sample DNA extract as qPCR template

- Duplicates - All samples were analyzed by qPCR in duplicate; final results represent an average of these.

- An evaluation of potential matrix effects on the qPCR was done by analyzing a portion of each sample that was spiked with a known quantity of target DNA. If matrix inhibition was present, sample DNA extracts were diluted accordingly and then processed by qPCR.

- Each qPCR run included a seven-point standard curve run in duplicate (serial dilutions of known quantities of target DNA). Conversion of qPCR output (cycle threshold [Ct] values) to MST marker concentrations for unknown samples was done by interpolating from these standard curves.

\section{Data Qualifications}

- Low-level cross contamination may occur during sample manipulation. Additionally, the production of autofluorescence or primer dimers for some of the qPCR assays may produce false positives (Bustin and others, 2009). If detections are found in the blank samples, the limit of blanks is calculated and used in determining the detection limit of an assay. This is defined as the 95 th percentile of all $\mathrm{Ct}$ values for the blanks for a specific assay.

- A limit of detection was established for each assay. The limit of detection is the lowest concentration that is detected with 95-percent confidence. If the limit of blanks has a higher concentration than the limit of detection, the limit of blanks is used as the detection limit. Results for samples that are below either limit are reported as less than the detection limit.

- Low-level quantification can be unreliable. To avoid misinterpretation of unreliable results, a limit of quantification was established for each assay. The limit of qualification was established by using the average $\mathrm{Ct}$ value of the limit of detection and subtracting 2 times the standard deviation of those $\mathrm{Ct}$ values. The result for a sample that detected the target DNA and is above the limit of detection but below the limit of quantification is reported with an "E" to denote that it is an estimated value.

- Along with the "E," there may also be a value qualifier. The "b" value qualifier means that the reported concentration was extrapolated below the limit of quantification but is above the limit of detection. The " $\sim$ " value qualifier means that the duplicate qPCR results do not agree.

An in-laboratory contamination event likely occurred for one of the field blanks analyzed in this sample set. The HF183 marker result for this sample exceeded the limits of detection and quantification for this assay. Thus, this value was factored into the calculation of the limit of blanks, and it was used as the detection limit for samples processed in this run. Additionally, the quantity of HF183 calculated in this sample was subtracted from any sample that was positive in this run. For all samples with detections of HF183 for this batch of data, the results were given a remark code of "V" (result may be affected by contamination), a value-qualifier code of "c" (see laboratory comment), and a laboratory comment indicating that contamination was found in a blank sample. 


\section{References Cited}

Bustin, S.A., Benes, V., Garson, J.A., Hellemans, J., Huggett, J., Kubista, M., Mueller, R., Nolan, T., Pfaffl, M.W., Shipley, G.L., Vandesompele, J., and Wittwer, C.T., 2009, The MIQE guidelines-Minimum information for publication of quantitative real-time PCR experiments: Clinical Chemistry, v. 55, no. 4, p. 611-622.

Green, H.C., Dick, L.K., Gilpin, B., Samadpour, M., and Field, K.G., 2012, Genetic markers for rapid PCR-based identification of gull, Canada goose, duck, and chicken fecal contamination in water: Applied and Environmental Microbiology, v. 78, no. 2, p. 503-510. https://doi.org/ 10.1128/AEM.05734-11.

Griffin, D.W., Stokes, R., Rose, J.B., and Paul, J.H., III, 2000, Bacterial indicator occurrence and the use of an F+-specific RNA coliphage assay to identify fecal sources in Homosassa Springs, Florida: Microbial Ecology, v. 39, p. 56-64, accessed March 4, 2020, at https://doi.org/ $10.1007 / \mathrm{s} 002489900193$.

Kildare, B.J., Leutenegger, C.M., McSwain, B.S., Bambic, D.G., Rajal, V.B., and Wuertz, S., 2007, 16S rRNA-based assays for quantitative detection of universal, human-, cow-, and dog-specific fecal Bacteroidales-A Bayesian approach: Water Research, v. 41, no. 16, p. 3701-3715, accessed March 4, 2020, at https://doi.org/10.1016/ j.watres.2007.06.037.

Mieszkin, S., Yala, J.F., Joubrel, R., and Gourmelon, M., 2010, Phylogenetic analysis of Bacteroidales 16S rRNA gene sequences from human and animal effluents and assessment of ruminant faecal pollution by real-time PCR: Journal of Applied Microbiology, v. 108, no. 3, p. 974-984, accessed March 4, 2020, at https://doi.org/10.1111/j.13652672.2009.04499.x.

Seurinck, S., Defoirdt, T., Verstraete, W., and Siciliano, S.D., 2005, Detection and quantification of the human-specific HF183 Bacteroides 16S rRNA genetic marker with realtime PCR for assessment of human faecal pollution in freshwater: Environmental Microbiology, v. 7, no. 2, p. 249-259, accessed March 4, 2020, at https://doi.org/10.1111/j.14622920.2004.00702.x.

Wolf, S., Hewitt, J., Rivera-Aban, M., and Greening, G.E., 2008 , Detection and characterization of $\mathrm{F}^{+}$RNA bacteriophages in water and shellfish-Application of a multiplex real-time reverse transcription PCR: Journal of Virological Methods, v. 149, no. 1, p. 123-128, accessed March 4, 2020, at https://doi.org/10.1016/j.jviromet.2007.12.012. 


\section{Appendix 2. Surface-Water Clarity Plot and Groundwater Constituents}

Secchi depth correlations with turbidity and chlorophyll $a$ at Hook Pond are presented in figure 2.1. Chlorophyll $a$ correlation with $\mathrm{pH}$ at Hook Pond and along Hook Pond Dreen is presented in figure 2.2. A summary of results of water temperature, specific conductance, and water-surface elevation by week measured by the continuous water-quality monitor at Hook Pond site 10 are presented in table 2.1. A summary of results of the physicochemical constituent values measured in Hook Pond and Hook Pond Dreen are presented seasonally by site in tables 2.2 and 2.3. Physicochemical constituents measured in groundwater during pumping are presented in table 2.4. Data generated or collected during this study are available in tables within this report and from the USGS National Water Information System database (USGS, 2020a)

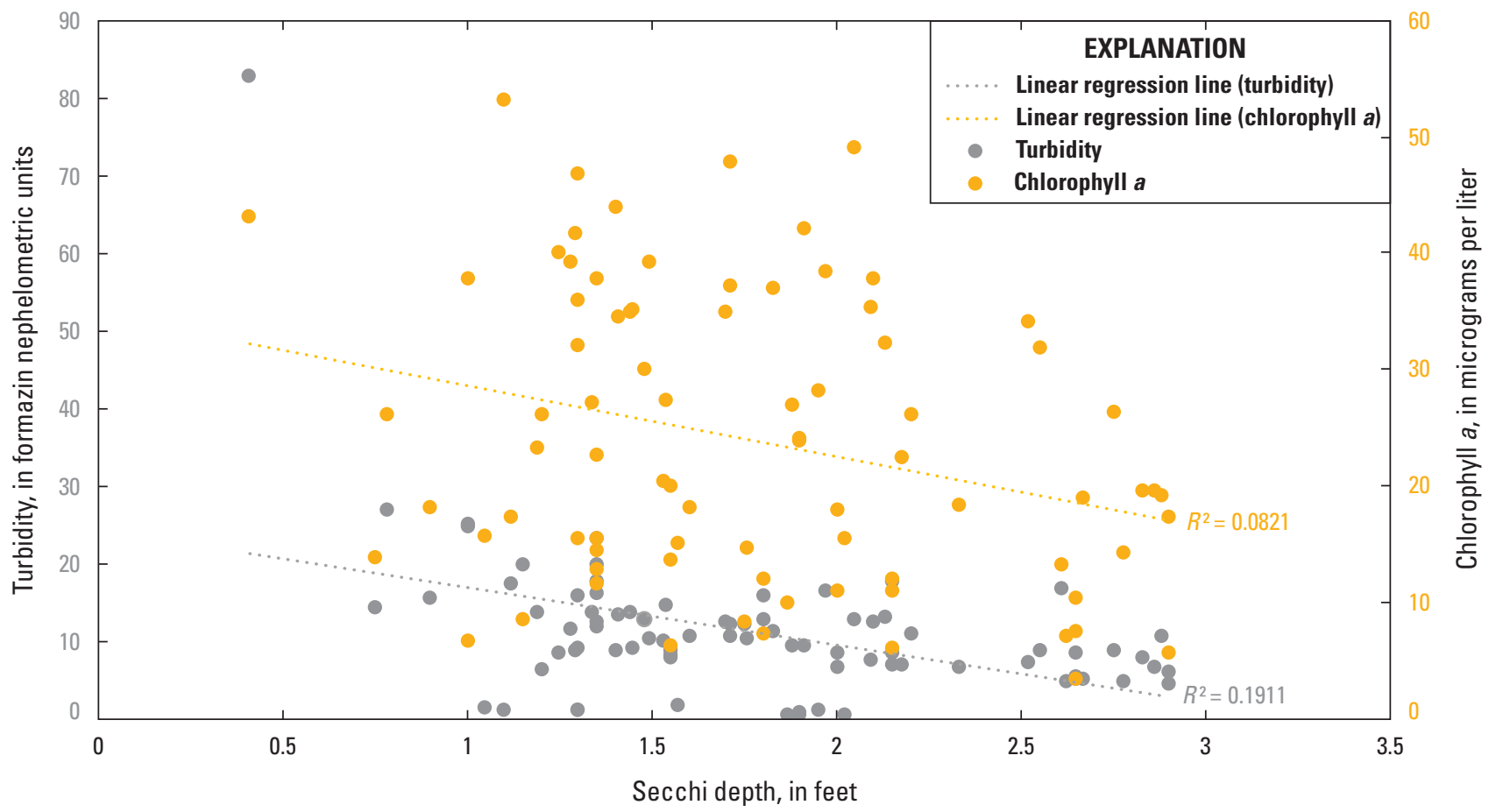

Figure 2.1. Comparison of surface measurements of turbidity and chlorophyll $a$ and Secchi depth throughout Hook Pond (sites 1-8 and 10), in East Hampton, New York, between August 2017 and August 2018. The $R^{2}$ values indicate little correlation between either physicochemical constituent and Secchi depth, which is a measure of water clarity. 


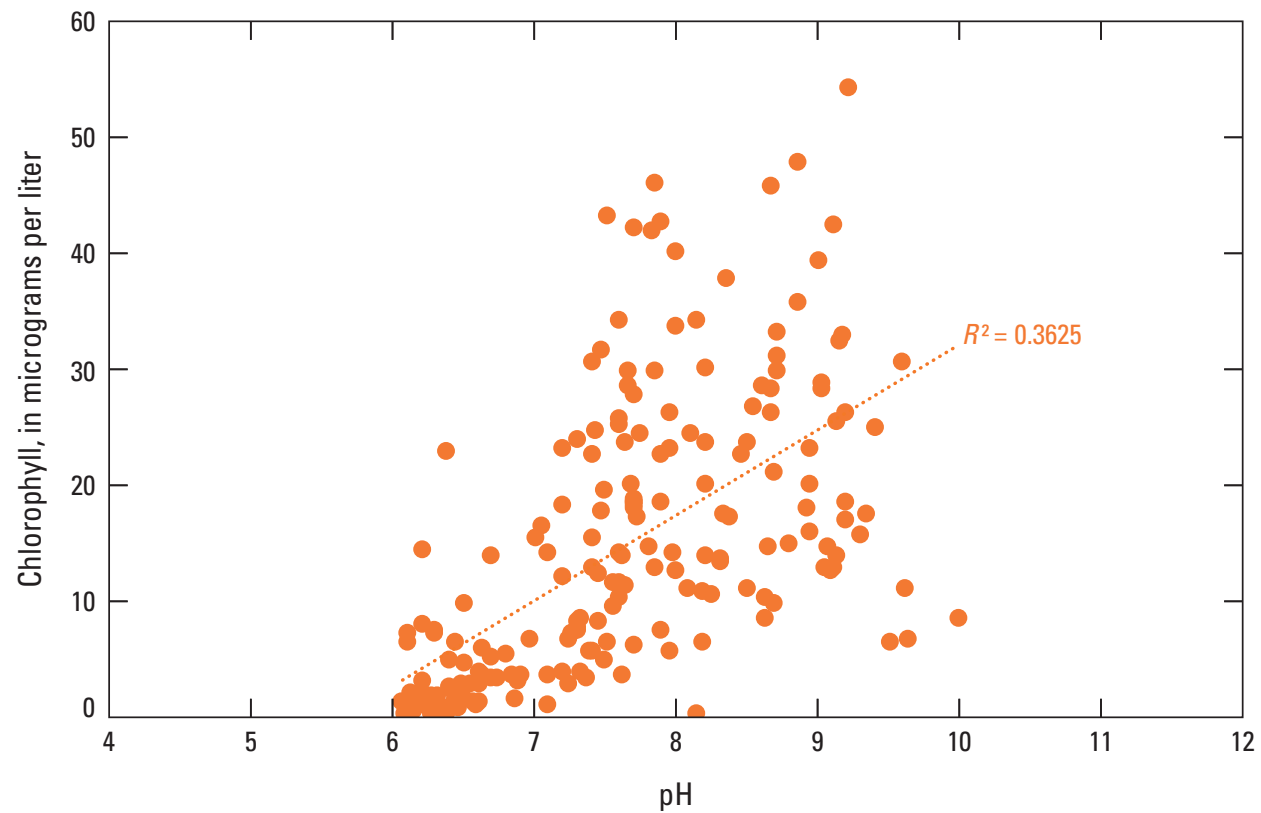

Figure 2.2. Comparison of surface measurements of chlorophyll $a$ and $\mathrm{pH}$ throughout Hook Pond (sites 1-8 and 10) and along Hook Pond Dreen, in East Hampton, New York, between August 2017 and August 2018. The $R^{2}$ value indicates a weak correlation between the two constituents, with lower $\mathrm{pH}$ and chlorophyll a concentrations measured in Hook Pond Dreen as a result of groundwater seepage, consistent flow, and more tree canopy creating shade. 
Table 2.1. Summary of continuous water-quality monitoring at Hook Pond Maidstone Club golf cart bridge site, East Hampton, New York.

[ft, foot; NAVD 88, North American Vertical Datum of $1988 ;{ }^{\circ} \mathrm{C}$, degree Celsius; $\mu \mathrm{S} / \mathrm{cm}$ at $25^{\circ} \mathrm{C}$, microsiemens per centimeter at 25 degrees Celsius; - , no data.]

\begin{tabular}{|c|c|c|c|c|c|c|c|c|c|c|}
\hline \multirow[t]{2}{*}{ Week } & \multirow{2}{*}{ Date range } & \multicolumn{3}{|c|}{$\begin{array}{c}\text { Elevation } \\
\text { (ft above NAVD 88) }\end{array}$} & \multicolumn{3}{|c|}{$\begin{array}{c}\text { Temperature } \\
\left({ }^{\circ} \mathrm{C}\right)\end{array}$} & \multicolumn{3}{|c|}{$\begin{array}{l}\text { Specific conductance } \\
\left(\mu \mathrm{S} / \mathrm{cm} \text { at } 25^{\circ} \mathrm{C}\right)\end{array}$} \\
\hline & & Minimum & Median & Maximum & Minimum & Median & Maximum & Minimum & Median & Maximum \\
\hline 1 & 08/06/2017-08/12/2017 & 3.81 & 3.91 & 3.95 & 23.6 & 25.7 & 28.7 & - & - & - \\
\hline 2 & 08/13/2017-08/19/2017 & 3.68 & 3.91 & 3.91 & 23.4 & 26.1 & 29.9 & - & - & - \\
\hline 3 & 08/20/2017-08/26/2017 & 3.60 & 3.79 & 3.84 & 22.4 & 25.4 & 29.6 & - & - & - \\
\hline 4 & 08/27/2017-09/02/2017 & 3.75 & 3.73 & 4.00 & 17.0 & 21.2 & 26.8 & - & - & - \\
\hline 5 & 09/03/2017-09/09/2017 & 3.72 & 3.84 & 4.07 & 16.4 & 21.2 & 26.0 & - & - & - \\
\hline 6 & 09/10/2017-09/16/2017 & 3.77 & 3.92 & 3.97 & 18.3 & 23.2 & 27.8 & 296 & 314 & 321 \\
\hline 7 & 09/17/2017-09/23/2017 & 3.76 & 3.91 & 4.09 & 17.0 & 21.0 & 26.9 & 315 & 322 & 342 \\
\hline 8 & 09/24/2017-09/30/2017 & 3.82 & 3.94 & 4.30 & 15.5 & 22.5 & 27.3 & 265 & 344 & 383 \\
\hline 9 & $10 / 01 / 2017-10 / 07 / 2017$ & 4.06 & 4.01 & 4.24 & 14.3 & 18.9 & 23.9 & 282 & 309 & 330 \\
\hline 10 & $10 / 08 / 2017-10 / 14 / 2017$ & 3.99 & 4.12 & 4.12 & 13.4 & 19.2 & 23.6 & 310 & 322 & 356 \\
\hline 11 & $10 / 15 / 2017-10 / 21 / 2017$ & 3.96 & 4.06 & 4.07 & 11.3 & 15.9 & 19.8 & 310 & 324 & 342 \\
\hline 12 & $10 / 22 / 2017-10 / 28 / 2017$ & 3.87 & 4.01 & 4.30 & 12.7 & 17.1 & 20.4 & 223 & 293 & 338 \\
\hline 13 & 10/29/2017-11/04/2017 & 4.07 & 4.02 & 4.62 & 10.9 & 14.3 & 18.1 & 187 & 268 & 310 \\
\hline 14 & $11 / 05 / 2017-11 / 11 / 2017$ & 3.75 & 4.35 & 4.32 & 1.70 & 10.3 & 16.1 & 289 & 303 & 342 \\
\hline 15 & $11 / 12 / 2017-11 / 18 / 2017$ & 3.70 & 4.05 & 3.97 & 2.80 & 6.42 & 9.90 & 318 & 331 & 355 \\
\hline 16 & $11 / 19 / 2017-11 / 25 / 2017$ & 3.75 & 3.84 & 4.22 & 4.00 & 7.20 & 12.2 & 239 & 286 & 334 \\
\hline 17 & $11 / 26 / 2017-12 / 02 / 2017$ & 3.63 & 3.91 & 3.93 & 3.40 & 7.25 & 10.4 & 285 & 323 & 346 \\
\hline 18 & $12 / 03 / 2017-12 / 09 / 2017$ & 3.71 & 3.79 & 4.11 & 2.70 & 6.69 & 11.6 & 305 & 322 & 343 \\
\hline 19 & $12 / 10 / 2017-12 / 16 / 2017$ & 3.44 & 3.93 & 3.71 & -0.20 & 3.02 & 6.50 & 324 & 351 & 398 \\
\hline 20 & $12 / 17 / 2017-12 / 23 / 2017$ & 3.35 & 3.60 & 3.78 & 0.80 & 3.75 & 7.60 & 341 & 363 & 390 \\
\hline 21 & $12 / 24 / 2017-12 / 30 / 2017$ & 3.76 & 3.57 & 3.90 & -0.30 & 3.80 & 7.00 & 344 & 376 & 407 \\
\hline 22 & $12 / 31 / 2017-01 / 06 / 2018$ & 3.86 & 3.91 & 4.00 & 3.00 & 4.35 & 5.00 & 385 & 410 & 451 \\
\hline 23 & 01/07/2018-01/13/2018 & 3.63 & 3.90 & 4.04 & 2.20 & 4.56 & 5.70 & 317 & 379 & 503 \\
\hline 24 & $01 / 14 / 2018-01 / 20 / 2018$ & 3.63 & 3.73 & 3.86 & 2.70 & 4.63 & 5.90 & 268 & 322 & 451 \\
\hline 25 & $01 / 21 / 2018-01 / 27 / 2018$ & 3.86 & 4.12 & 4.24 & -0.20 & 3.41 & 5.50 & 217 & 264 & 339 \\
\hline 26 & $01 / 28 / 2018-02 / 03 / 2018$ & 3.84 & 4.12 & 4.17 & -0.30 & 2.79 & 5.60 & 265 & 306 & 483 \\
\hline 27 & $02 / 04 / 2018-02 / 10 / 2018$ & 3.66 & 3.73 & 3.90 & 1.20 & 3.42 & 6.40 & 252 & 347 & 484 \\
\hline 28 & $02 / 11 / 2018-02 / 17 / 2018$ & 3.70 & 3.77 & 3.95 & 1.40 & 6.56 & 10.2 & 274 & 310 & 322 \\
\hline 29 & $02 / 18 / 2018-02 / 24 / 2018$ & 3.86 & 3.98 & 4.04 & 4.80 & 7.83 & 11.0 & 272 & 322 & 334 \\
\hline 30 & $02 / 25 / 2018-03 / 03 / 2018$ & 3.69 & 3.89 & 4.19 & 4.30 & 7.31 & 11.6 & 264 & 307 & 1,920 \\
\hline 31 & 03/04/2018-03/10/2018 & 3.96 & 4.18 & 4.38 & 2.40 & 5.37 & 8.10 & 982 & 2,070 & 11,300 \\
\hline 32 & 03/11/2018-03/17/2018 & 3.74 & 3.91 & 4.06 & -0.20 & 4.34 & 8.40 & 527 & 886 & 2,200 \\
\hline 33 & 03/18/2018-03/24/2018 & 3.61 & 3.77 & 3.89 & 0.00 & 4.75 & 10.8 & 386 & 582 & 1,020 \\
\hline 34 & 03/25/2018-03/31/2018 & 3.70 & 3.74 & 3.90 & 3.90 & 8.97 & 14.2 & 430 & 562 & 943 \\
\hline 35 & 04/01/2018-04/07/2018 & 3.62 & 3.80 & 3.96 & 3.40 & 7.27 & 11.6 & 377 & 453 & 751 \\
\hline 36 & 04/08/2018-04/14/2018 & 3.55 & 3.71 & 3.91 & 3.60 & 9.33 & 17.0 & 369 & 397 & 502 \\
\hline 37 & $04 / 15 / 2018-04 / 21 / 2018$ & 3.72 & 3.94 & 4.17 & 5.30 & 8.80 & 15.5 & 400 & 474 & 659 \\
\hline 38 & $04 / 22 / 2018-04 / 28 / 2018$ & 3.78 & 3.90 & 4.02 & 10.0 & 14.4 & 18.8 & 310 & 371 & 449 \\
\hline 39 & $04 / 29 / 2018-05 / 05 / 2018$ & 3.66 & 3.77 & 3.94 & 10.4 & 15.8 & 21.1 & 328 & 367 & 407 \\
\hline 40 & 05/06/2018-05/12/2018 & 3.94 & 4.05 & 4.07 & 13.5 & 18.1 & 22.5 & 349 & 369 & 414 \\
\hline
\end{tabular}


Table 2.1. Summary of continuous water-quality monitoring at Hook Pond Maidstone Club golf cart bridge site, East Hampton, New York.-Continued

[ft, foot; NAVD 88, North American Vertical Datum of $1988 ;{ }^{\circ} \mathrm{C}$, degree Celsius; $\mu \mathrm{S} / \mathrm{cm}$ at $25^{\circ} \mathrm{C}$, microsiemens per centimeter at 25 degrees Celsius; - , no data.]

\begin{tabular}{|c|c|c|c|c|c|c|c|c|c|c|}
\hline \multirow[t]{2}{*}{ Week } & \multirow[t]{2}{*}{ Date range } & \multicolumn{3}{|c|}{$\begin{array}{c}\text { Elevation } \\
\text { (ft above NAVD 88) }\end{array}$} & \multicolumn{3}{|c|}{$\begin{array}{c}\text { Temperature } \\
\left({ }^{\circ} \mathrm{C}\right)\end{array}$} & \multicolumn{3}{|c|}{$\begin{array}{l}\text { Specific conductance } \\
\left(\mu \mathrm{S} / \mathrm{cm} \text { at } 25^{\circ} \mathrm{C}\right)\end{array}$} \\
\hline & & Minimum & Median & Maximum & Minimum & Median & Maximum & Minimum & Median & Maximum \\
\hline 41 & 05/13/2018-05/19/2018 & 3.80 & 4.02 & 4.11 & 12.0 & 16.1 & 21.7 & 337 & 369 & 415 \\
\hline 42 & 05/20/2018-05/26/2018 & 3.64 & 3.75 & 3.91 & 12.8 & 20.2 & 25.4 & 331 & 349 & 376 \\
\hline 43 & 05/27/2018-06/02/2018 & 3.91 & 4.02 & 4.37 & 14.2 & 20.9 & 26.4 & 233 & 354 & 375 \\
\hline 44 & 06/03/2018-06/09/2018 & 3.74 & 3.94 & 4.25 & 15.0 & 20.2 & 25.2 & 245 & 282 & 326 \\
\hline 45 & $06 / 10 / 2018-06 / 16 / 2018$ & 3.82 & 4.03 & 4.09 & 18.5 & 21.2 & 25.9 & 323 & 333 & 362 \\
\hline 46 & 06/17/2018-06/23/2018 & 3.96 & 4.12 & 4.18 & 19.2 & 24.1 & 28.5 & 327 & 337 & 349 \\
\hline 47 & 06/24/2018-06/30/2018 & 3.83 & 3.96 & 4.04 & 19.5 & 24.4 & 30.9 & 323 & 331 & 349 \\
\hline 48 & 07/01/2018-07/07/2018 & 4.04 & 4.09 & 4.11 & 21.2 & 28.2 & 32.6 & 336 & 344 & 352 \\
\hline 49 & 07/08/2018-07/14/2018 & 4.03 & 4.06 & 4.10 & 22.4 & 26.6 & 30.0 & 345 & 356 & 370 \\
\hline 50 & 07/15/2018-07/21/2018 & 4.01 & 4.07 & 4.13 & 23.2 & 27.3 & 31.1 & 323 & 358 & 366 \\
\hline 51 & $07 / 22 / 2018-07 / 28 / 2018$ & 3.74 & 3.91 & 4.05 & 22.1 & 27.1 & 31.6 & 310 & 331 & 353 \\
\hline 52 & 07/29/2018-08/04/2018 & 3.97 & 4.01 & 4.11 & 23.8 & 27.7 & 31.8 & 328 & 340 & 347 \\
\hline
\end{tabular}


Table 2.2. Summary of water-quality depth-profile data—temperature, specific conductance, dissolved oxygen, and pH—at sites throughout Hook Pond, select sites along Hook Pond Dreen, and at Town Pond, East Hampton, New York.

[Summary statistics are only shown if data from at least four readings in a season are available; missing summary data does not imply no data are available for a given season at a given site; complete dataset is available on the U.S. Geological Survey (USGS) National Water Information System database (USGS, 2020b). ${ }^{\circ} \mathrm{C}$, degree Celsius; $\mu \mathrm{S} / \mathrm{cm}$ at $25^{\circ} \mathrm{C}$, microsiemens per centimeter at 25 degrees Celsius; mg/L, milligram per liter; Min, minimum; Med, median; Max, maximum; ND, too few points to evaluate]

\begin{tabular}{|c|c|c|c|c|c|c|c|c|c|c|c|c|c|}
\hline \multirow[t]{2}{*}{ Site } & \multirow[t]{2}{*}{ Season } & \multicolumn{3}{|c|}{$\begin{array}{c}\text { Temperature } \\
\left({ }^{\circ} \mathrm{C}\right)\end{array}$} & \multicolumn{3}{|c|}{$\begin{array}{c}\text { Specific conductance } \\
\left(\mu \mathrm{S} / \mathrm{cm} \text { at } 25^{\circ} \mathrm{C}\right)\end{array}$} & \multicolumn{3}{|c|}{$\begin{array}{c}\text { Dissolved oxygen } \\
\text { (mg/L) }\end{array}$} & \multicolumn{3}{|c|}{$\begin{array}{c}\text { pH } \\
\text { (standard units) }\end{array}$} \\
\hline & & Min & Med & Max & Min & Med & Max & Min & Med & Max & Min & Med & Max \\
\hline \multirow{2}{*}{1} & Autumn & 6.50 & 20.5 & 24.1 & 315 & 399 & 496 & 0.20 & 12.7 & 16.3 & 6.40 & 8.65 & 9.60 \\
\hline & Winter & ND & $\mathrm{ND}$ & ND & ND & ND & ND & ND & ND & ND & ND & ND & ND \\
\hline \multirow{3}{*}{2} & Autumn & 6.86 & 15.4 & 20.7 & 317 & 349 & 455 & 8.70 & 10.3 & 12.8 & 7.58 & 7.70 & 7.80 \\
\hline & Winter & ND & ND & ND & ND & ND & ND & ND & ND & ND & ND & ND & ND \\
\hline & Spring & 9.70 & 16.8 & 18.3 & 504 & 539 & 764 & 10.4 & 11.0 & 12.5 & 7.50 & 8.07 & 8.35 \\
\hline 3 & Summer & 20.6 & 25.6 & 29.1 & 340 & 396 & 580 & 3.70 & 10.2 & 12.8 & 7.80 & 8.70 & 9.20 \\
\hline \multirow[t]{4}{*}{4} & Summer & 19.9 & 25.6 & 31.0 & 340 & 401 & 445 & 8.90 & 10.8 & 14.5 & 6.50 & 8.00 & 9.22 \\
\hline & Autumn & 7.90 & 21.0 & 24.4 & 319 & 457 & 654 & 8.70 & 11.6 & 13.0 & 6.80 & 7.50 & 8.30 \\
\hline & Winter & ND & ND & ND & ND & ND & ND & ND & ND & ND & ND & ND & ND \\
\hline & Spring & 16.8 & 16.9 & 20.6 & 405 & 429 & 516 & 9.69 & 10.0 & 11.6 & 7.10 & 7.26 & 7.40 \\
\hline \multirow[t]{4}{*}{5} & Summer & 19.2 & 24.8 & 30.2 & 319 & 348 & 536 & 6.40 & 10.0 & 12.6 & 7.20 & 8.55 & 9.14 \\
\hline & Autumn & 7.10 & 22.8 & 24.5 & 317 & 511 & 596 & 1.30 & 11.7 & 12.8 & 7.50 & 7.95 & 8.40 \\
\hline & Winter & ND & ND & ND & ND & ND & ND & ND & ND & ND & ND & ND & ND \\
\hline & Spring & 10.0 & 17.1 & 19.9 & 460 & 591 & 670 & 8.77 & 11.8 & 12.2 & 7.20 & 7.84 & 8.58 \\
\hline 6 & Summer & 18.9 & 23.6 & 29.1 & 317 & 327 & 340 & 2.60 & 9.20 & 14.0 & 7.20 & 7.60 & 8.50 \\
\hline \multirow{2}{*}{7} & Winter & 2.90 & 4.30 & 6.90 & 470 & 2,637 & 3,178 & 12.5 & 13.3 & 14.4 & 7.37 & 7.40 & 7.60 \\
\hline & Spring & ND & ND & ND & ND & ND & ND & ND & ND & ND & ND & ND & ND \\
\hline \multirow[t]{4}{*}{8} & Summer & 19.4 & 23.6 & 26.5 & 321 & 335 & 344 & 6.60 & 8.60 & 12.9 & 6.90 & 7.40 & 8.00 \\
\hline & Autumn & 12.9 & 17.3 & 20.6 & 229 & 297 & 311 & 9.30 & 10.1 & 10.6 & 7.20 & 7.40 & 7.90 \\
\hline & Winter & $\mathrm{ND}$ & ND & ND & ND & ND & ND & ND & ND & ND & ND & ND & ND \\
\hline & Spring & 10.5 & 18.1 & 20.2 & 347 & 351 & 370 & 7.20 & 11.1 & 12.4 & 6.70 & 7.33 & 8.63 \\
\hline \multirow[t]{4}{*}{10} & Summer & 20.4 & 25.6 & 28.6 & 293 & 333 & 363 & 5.9 & 9.7 & 11.1 & 6.86 & 8.00 & 8.85 \\
\hline & Autumn & 6.40 & 15.6 & 24.3 & 325 & 335 & 343 & 8.9 & 10.2 & 12.7 & 6.90 & 7.50 & 7.70 \\
\hline & Winter & 1.60 & 3.28 & 4.60 & 345 & 940 & 945 & 13.1 & 13.2 & 15.3 & 7.18 & 7.30 & 7.50 \\
\hline & Spring & 11.0 & 14.1 & 17.4 & 348 & 364 & 387 & 7.5 & 11.3 & 12.0 & 5.60 & 6.85 & 7.69 \\
\hline
\end{tabular}


Table 2.2. Summary of water-quality depth-profile data—temperature, specific conductance, dissolved oxygen, and pH—at sites throughout Hook Pond, select sites along Hook Pond Dreen, and at Town Pond, East Hampton, New York.-Continued

[Summary statistics are only shown if data from at least four readings in a season are available; missing summary data does not imply no data are available for a given season at a given site; complete dataset is available on the U.S. Geological Survey (USGS) National Water Information System database (USGS, 2020b). ${ }^{\circ} \mathrm{C}$, degree Celsius; $\mu \mathrm{S} / \mathrm{cm}$ at $25^{\circ} \mathrm{C}$, microsiemens per centimeter at 25 degrees Celsius; mg/L, milligram per liter; Min, minimum; Med, median; Max, maximum; ND, too few points to evaluate]

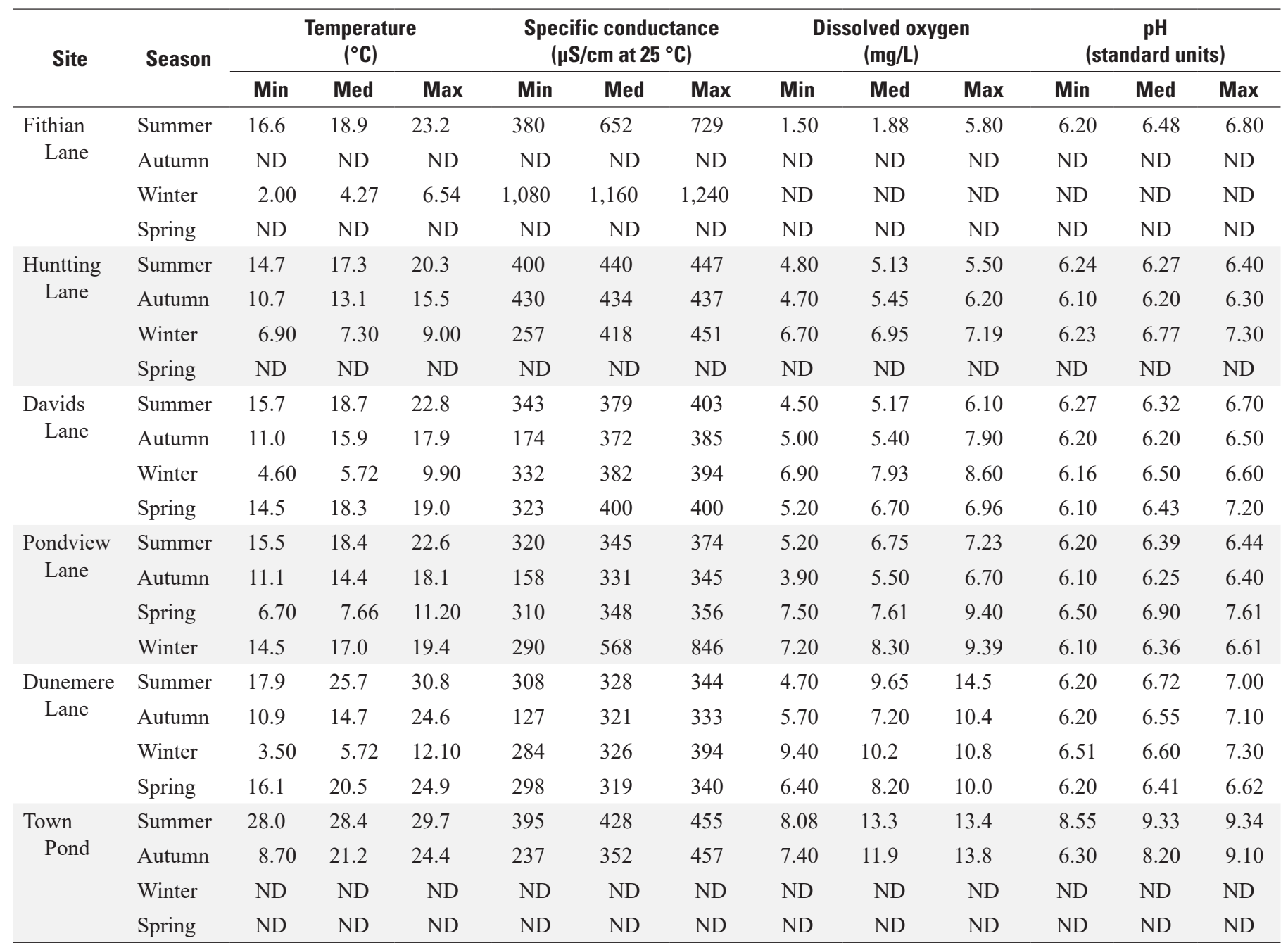


Table 2.3. Summary of water-quality depth-profile data-turbidity, chlorophyll a fluorescence, and phycocyanin fluorescence-at sites throughout Hook Pond, select sites along Hook Pond Dreen, and at Town Pond, East Hampton, New York.

[Summary statistics are only shown if data from at least four readings in a season are available; missing summary data does not imply no data are available for a given season at a given site; complete dataset is available on the U.S. Geological Survey (USGS) National Water Information System database (USGS, 2020b). FNU, formazin nephelometric unit; $\mu \mathrm{g} / \mathrm{L}$, microgram per liter; Min, minimum; Med, median; Max, maximum; ND, too few points to evaluate]

\begin{tabular}{|c|c|c|c|c|c|c|c|c|c|c|}
\hline \multirow[t]{2}{*}{ Site } & \multirow[t]{2}{*}{ Season } & \multicolumn{3}{|c|}{$\begin{array}{c}\text { Turbidity, } \\
\text { in situ (FNU) }\end{array}$} & \multicolumn{3}{|c|}{$\begin{array}{l}\text { Chlorophyll a fluorescence, } \\
\text { in situ ( } \mu \mathrm{g} / \mathrm{L})\end{array}$} & \multicolumn{3}{|c|}{$\begin{array}{l}\text { Phycocyanin fluorescence, } \\
\text { in situ ( } \mu \mathrm{g} / \mathrm{L})\end{array}$} \\
\hline & & Min & Med & Max & Min & Med & Max & Min & Med & Max \\
\hline \multirow{2}{*}{1} & Autumn & 3.30 & 4.40 & 15.0 & 4.70 & 6.30 & 11.5 & 0.18 & 0.26 & 0.56 \\
\hline & Winter & ND & ND & ND & ND & ND & ND & ND & ND & ND \\
\hline \multirow{3}{*}{2} & Autumn & 5.00 & 6.70 & 9.50 & 11.3 & 18.1 & 42.1 & 0.55 & 0.78 & 1.34 \\
\hline & Winter & ND & ND & ND & ND & ND & ND & ND & ND & ND \\
\hline & Spring & 6.00 & 7.43 & 8.63 & 4.80 & 9.40 & 23.7 & 0.17 & 0.24 & 0.53 \\
\hline 3 & Summer & 0.30 & 8.40 & 14.1 & 8.10 & 27.5 & 54.8 & 0.09 & 0.99 & 2.43 \\
\hline \multirow[t]{4}{*}{4} & Summer & 0.50 & 7.40 & 81.4 & 9.30 & 21.0 & 54.3 & 0.20 & 0.71 & 2.93 \\
\hline & Autumn & 3.60 & 5.00 & 13.0 & 11.6 & 17.2 & 49.6 & 0.50 & 0.80 & 2.60 \\
\hline & Winter & ND & ND & ND & ND & ND & ND & ND & ND & ND \\
\hline & Spring & 4.66 & 4.71 & 12.6 & 4.74 & 7.02 & 22.6 & 0.11 & 0.16 & 0.58 \\
\hline \multirow[t]{4}{*}{5} & Summer & 0.60 & 12.0 & 60.0 & 10.4 & 24.5 & 35.9 & 0.61 & 0.78 & 2.35 \\
\hline & Autumn & 6.90 & 13.0 & 31.0 & 14.6 & 22.2 & 50.1 & 0.60 & 1.07 & 2.18 \\
\hline & Winter & ND & ND & ND & ND & ND & ND & ND & ND & ND \\
\hline & Spring & 5.40 & 6.70 & 16.9 & 5.40 & 6.70 & 13.3 & 0.17 & 0.20 & 0.48 \\
\hline 6 & Summer & 0.70 & 11.5 & 25.0 & 3.40 & 15.0 & 37.9 & 0.00 & 0.58 & 2.37 \\
\hline \multirow{2}{*}{7} & Winter & 5.20 & 5.85 & 10.4 & 3.18 & 3.35 & 24.7 & 0.20 & 0.24 & 0.91 \\
\hline & Spring & ND & ND & ND & ND & ND & ND & ND & ND & ND \\
\hline \multirow[t]{4}{*}{8} & Summer & 0.90 & 10.5 & 20.0 & 1.50 & 8.60 & 18.6 & 0.00 & 0.31 & 1.11 \\
\hline & Autumn & 5.50 & 13.5 & 18.0 & 5.60 & 7.50 & 16.1 & 0.25 & 0.30 & 0.90 \\
\hline & Winter & ND & ND & ND & ND & ND & ND & ND & ND & ND \\
\hline & Spring & 10.3 & 11.8 & 20.0 & 2.50 & 3.40 & 8.50 & 0.15 & 0.17 & 0.90 \\
\hline \multirow[t]{4}{*}{10} & Summer & 0.00 & 9.50 & 24.0 & 0.00 & 14.5 & 45.8 & 0.00 & 0.38 & 0.73 \\
\hline & Autumn & 4.20 & 5.90 & 14.0 & 3.50 & 5.95 & 12.9 & 0.15 & 0.26 & 0.70 \\
\hline & Winter & 4.50 & 24.6 & 29.0 & 4.00 & 6.10 & 7.18 & 0.31 & 0.42 & 0.50 \\
\hline & Spring & 0.00 & 6.25 & 10.3 & 0.00 & 4.60 & 7.22 & 0.00 & 0.19 & 0.20 \\
\hline
\end{tabular}


Table 2.3. Summary of water-quality depth-profile data-turbidity, chlorophyll a fluorescence, and phycocyanin fluorescence-at sites throughout Hook Pond, select sites along Hook Pond Dreen, and at Town Pond, East Hampton, New York.-Continued

[Summary statistics are only shown if data from at least four readings in a season are available; missing summary data does not imply no data are available for a given season at a given site; complete dataset is available on the U.S. Geological Survey (USGS) National Water Information System database (USGS, 2020b). FNU, formazin nephelometric unit; $\mu \mathrm{g} / \mathrm{L}$, microgram per liter; Min, minimum; Med, median; Max, maximum; ND, too few points to evaluate]

\begin{tabular}{|c|c|c|c|c|c|c|c|c|c|c|}
\hline \multirow[t]{2}{*}{ Site } & \multirow[t]{2}{*}{ Season } & \multicolumn{3}{|c|}{$\begin{array}{c}\text { Turbidity, } \\
\text { in situ (FNU) }\end{array}$} & \multicolumn{3}{|c|}{$\begin{array}{c}\text { Chlorophyll a fluorescence, } \\
\text { in situ ( } \mu \mathrm{g} / \mathrm{L})\end{array}$} & \multicolumn{3}{|c|}{$\begin{array}{l}\text { Phycocyanin fluorescence, } \\
\text { in situ ( } \mu \mathrm{g} / \mathrm{L})\end{array}$} \\
\hline & & Min & Med & Max & Min & Med & Max & Min & Med & Max \\
\hline \multirow{2}{*}{ Fithian Lane } & Autumn & ND & ND & ND & ND & ND & ND & ND & ND & ND \\
\hline & Winter & 4.13 & 4.13 & 4.13 & ND & ND & ND & ND & ND & ND \\
\hline \multirow{3}{*}{ Huntting Lane } & Autumn & 0.90 & 9.45 & 18.0 & 0.25 & 0.28 & 0.30 & 0.03 & 0.04 & 0.05 \\
\hline & Winter & 2.84 & 5.07 & 7.30 & ND & ND & ND & ND & ND & ND \\
\hline & Spring & ND & ND & ND & ND & ND & ND & ND & ND & ND \\
\hline Davids Lane & Summer & 3.30 & 10.4 & 21.0 & 1.29 & 1.70 & 5.29 & 0.00 & 0.09 & 0.28 \\
\hline \multirow[t]{4}{*}{ Pondview Lane } & Summer & 1.40 & 3.04 & 9.30 & 0.71 & 5.59 & 22.9 & 0.00 & 0.09 & 0.89 \\
\hline & Autumn & 0.80 & 2.40 & 11.0 & 0.29 & 0.80 & 7.40 & 0.03 & 0.06 & 0.15 \\
\hline & Spring & 2.15 & 2.20 & 2.50 & 1.37 & 2.86 & 4.35 & 0.00 & 0.10 & 0.15 \\
\hline & Winter & 5.05 & 7.53 & 10.0 & 3.78 & 5.50 & 7.22 & 0.05 & 0.13 & 0.20 \\
\hline \multirow[t]{4}{*}{ Dunemere Lane } & Summer & 2.80 & 6.90 & 17.7 & 0.95 & 3.34 & 15.7 & 0.00 & 0.07 & 0.25 \\
\hline & Autumn & 2.30 & 3.35 & 21.0 & 0.25 & 0.98 & 7.80 & 0.01 & 0.06 & 0.20 \\
\hline & Winter & 3.50 & 7.23 & 12.0 & 2.77 & 3.64 & 4.50 & 0.24 & 0.25 & 0.25 \\
\hline & Spring & 6.42 & 9.56 & 12.7 & 3.03 & 3.26 & 3.49 & 0.05 & 0.06 & 0.06 \\
\hline Town Pond & Summer & 1.50 & 2.58 & 2.89 & 9.34 & 17.4 & 26.7 & 0.00 & 0.00 & 0.70 \\
\hline
\end{tabular}


Table 2.4. Physicochemical constituents of groundwater samples collected within Hook Pond watershed, East Hampton, New York.

[Dataset is also available on the U.S. Geological Survey (USGS) National Water Information System database (USGS, 2020b). ${ }^{\circ} \mathrm{C}$, degree Celsius; $\mu \mathrm{S} / \mathrm{cm}$ at $25^{\circ} \mathrm{C}$, microsiemens per centimeter at 25 degrees Celsius; mg/L, milligram per liter; FNU, formazin nephelometric unit; - , no data entered]

\begin{tabular}{|c|c|c|c|c|c|c|c|}
\hline Station name & $\begin{array}{c}\text { Sample } \\
\text { date }\end{array}$ & $\begin{array}{c}\text { Sample } \\
\text { time }\end{array}$ & $\begin{array}{l}\text { Temper- } \\
\text { ature } \\
\left({ }^{\circ} \mathrm{C}\right)\end{array}$ & $\begin{array}{c}\text { Specific } \\
\text { conductance } \\
\left(\mu \mathrm{S} / \mathrm{cm} \text { at } 25^{\circ} \mathrm{C}\right)\end{array}$ & $\begin{array}{l}\text { Dissolved } \\
\text { oxygen } \\
\text { (mg/L) }\end{array}$ & $\begin{array}{c}\mathrm{pH}, \\
\text { standard } \\
\text { units }\end{array}$ & $\begin{array}{l}\text { Turbidity, } \\
\text { in situ } \\
\text { (FNU) }\end{array}$ \\
\hline Temporary well at Fithian Lane & $6 / 20 / 2018$ & 0925 & 14.9 & 660 & 0.2 & 6.4 & 11 \\
\hline S115135.1 & $7 / 27 / 2018$ & 1100 & 13.6 & 176 & 5.1 & 5.7 & 1.0 \\
\hline Temporary well at end of Terbell Lane & $7 / 27 / 2018$ & 1300 & 18.1 & 695 & 0.1 & 6.0 & 47 \\
\hline Temporary well 01-Maidstone Club & $7 / 30 / 2018$ & 1030 & 20.1 & 196 & - & 6.1 & - \\
\hline Temporary well near Davids Lane (north) & $8 / 7 / 2018$ & 0945 & 17.6 & 258 & 6.5 & 6.1 & 2.0 \\
\hline
\end{tabular}

\section{References Cited}

U.S. Geological Survey [USGS], 2020a, USGS water data for the Nation: U.S. Geological Survey National Water Information System database, accessed June 9, 2020, at https://doi.org/10.5066/F7P55KJN.

U.S. Geological Survey [USGS], 2020b, Water quality samples for the Nation, in USGS water data for the Nation: U.S. Geological Survey National Water Information System database, accessed April 16, 2020, at https://doi.org/ $10.5066 / F 7 P 55 K J N$. [Site information directly accessible at https:/nwis.waterdata.usgs.gov/usa/nwis/qwdata.] 
For more information about this report, contact: Director, New York Water Science Center

U.S. Geological Survey

425 Jordan Road

Troy, NY 12180-8349

dc_ny@usgs.gov

(518) 285-5602

or visit our website at

https://www.usgs.gov/centers/ny-water

Publishing support provided by the

Pembroke Publishing Service Center 

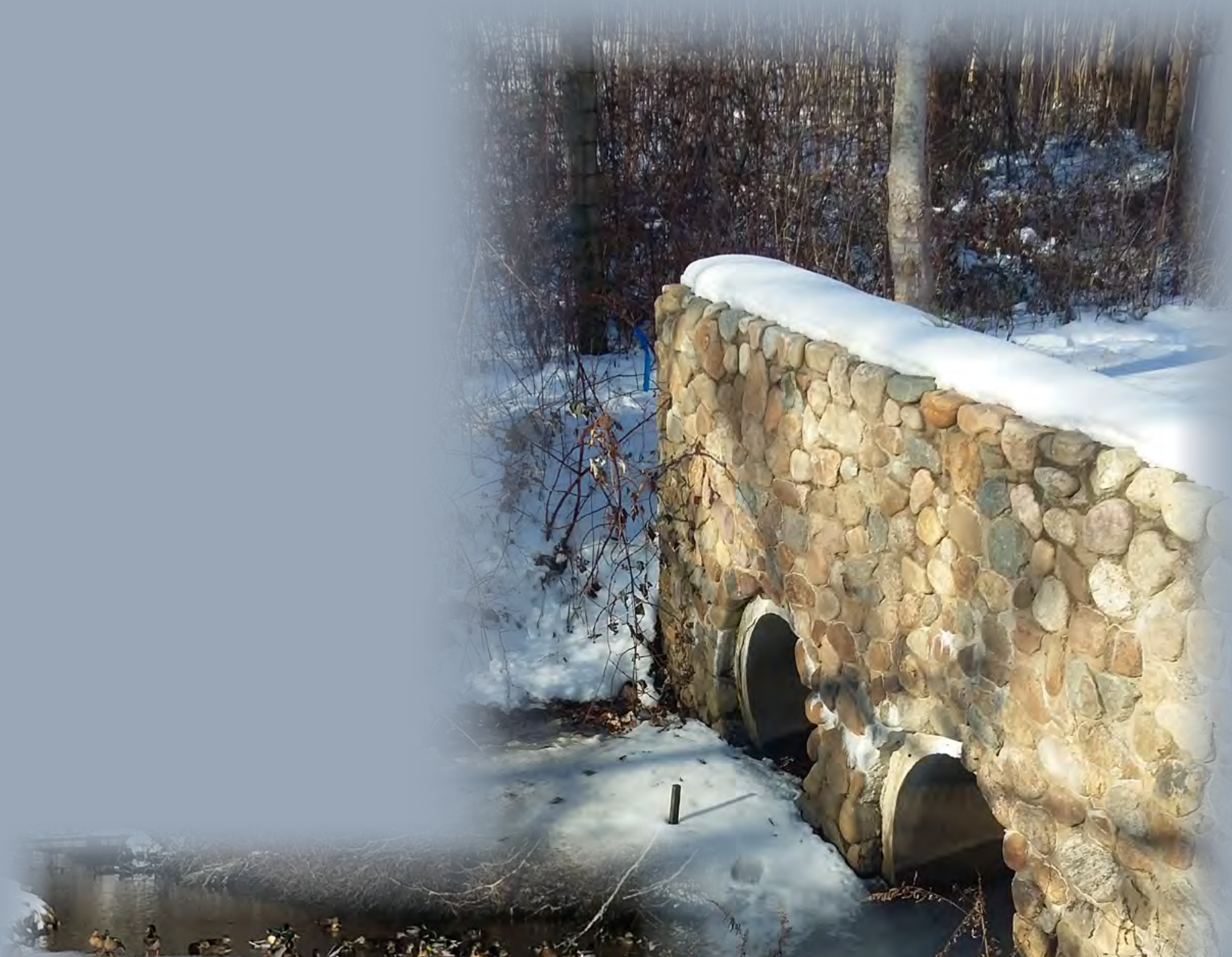

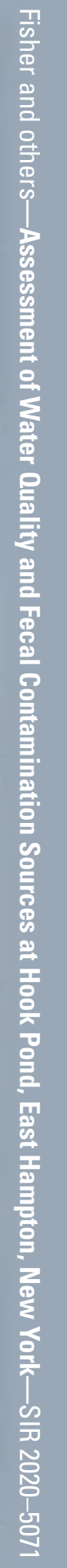

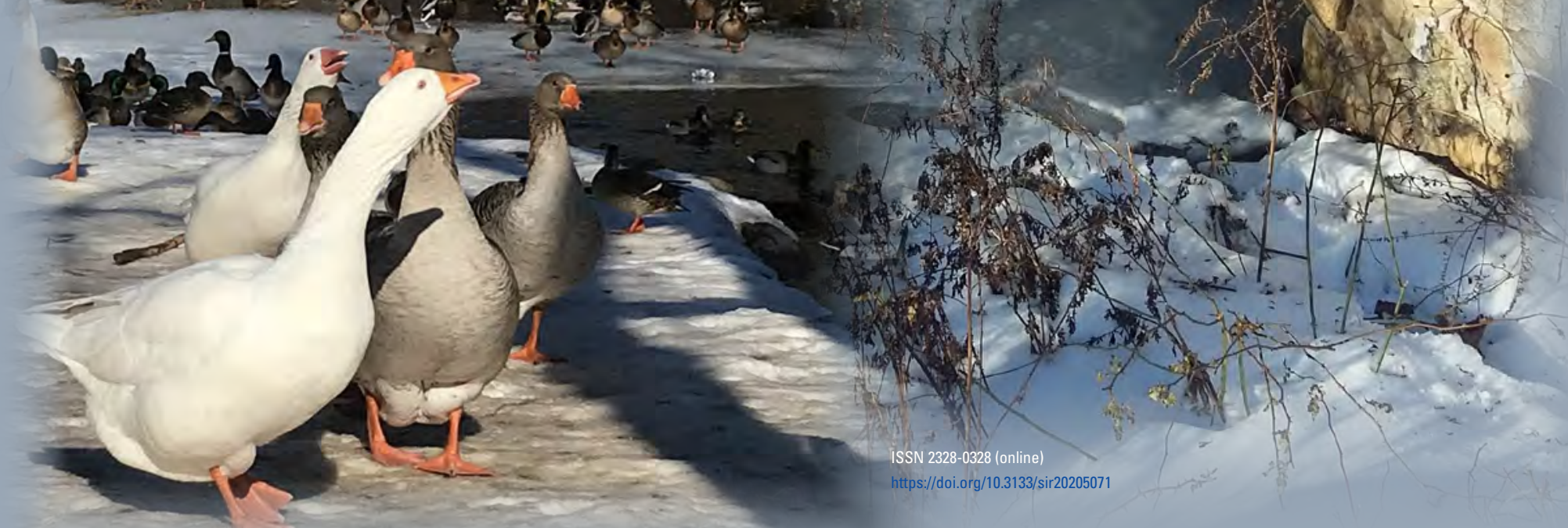

